UNIVERSIDADE DE SÃO PAULO

MARINA LEMOS RIO LIMA

OTIMIZAÇÃO TOPOLÓGICA E PARAMÉTRICA DE VIGAS DE CONCRETO ARMADO UTILIZANDO ALGORITMOS GENÉTICOS 
MARINA LEMOS RIO LIMA

\section{OTIMIZAÇÃO TOPOLÓGICA E PARAMÉTRICA DE VIGAS DE CONCRETO ARMADO UTILIZANDO ALGORITMOS GENÉTICOS}

Dissertação apresentada à Escola

Politécnica da Universidade de São Paulo para obtenção do título de Mestre em Engenharia. 
MARINA LEMOS RIO LIMA

\section{OTIMIZAÇÃO TOPOLÓGICA E PARAMÉTRICA DE VIGAS DE CONCRETO ARMADO UTILIZANDO ALGORITMOS GENÉTICOS}

Dissertação apresentada à Escola

Politécnica da Universidade de São Paulo para obtenção do título de Mestre em Engenharia.

Área de concentração:

Engenharia de Estruturas

Orientador:

Paulo de Mattos Pimenta 
Este exemplar foi revisado e alterado em relação à versão original, sob responsabilidade única do autor e com a anuência de seu orientador.

São Paulo, de julho de 2011.

Assinatura do autor

Assinatura do orientador

FICHA CATALOGRÁFICA

Lima, Marina Lemos Rio

Otimização topológica e paramétrica de vigas de concreto armado utilizando algoritmos genéticos / M.L.R. Lima. -- ed.rev. -- São Paulo, 2011.

$113 \mathrm{p}$.

Dissertação (Mestrado) - Escola Politécnica da Universidade de São Paulo. Departamento de Engenharia de Estruturas e Geotécnica.

1. Algoritmos genéticos 2. Vigas (Otimização) I. Universidade de São Paulo. Escola Politécnica. Departamento de Engenharia de Estruturas e Geotécnica II. t. 


\section{DEDICATÓRIA}

Dedico este trabalho à minha família. 


\section{AGRADECIMENTOS}

Gostaria de agradecer primeiramente a Deus pela força e inspiração que me foi dada nos momentos mais difíceis.

Ao meu pai, minha mãe, meus irmãos e toda minha família pelo apoio e compreensão.

Ao meu orientador, prof. Dr. Paulo de Mattos Pimenta.

Aos membros do JAC, que me propiciaram bons momentos de troca de informações.

Ao pessoal da Interact, pela ajuda e compreensão.

Aos amigos pelos momentos de descontração tão importantes.

Ao Olivier pela sua enorme paciência.

Á Universidade de São Paulo.

Enfim, a todos que colaboraram direta ou indiretamente para a elaboração deste trabalho. 
Podemos escolher recuar em direção à segurança ou avançar em direção ao crescimento. A opção pelo crescimento tem que ser feita repetidas vezes. E 0 medo tem que ser superado a cada momento.

(Abraham Maslow) 


\section{RESUMO}

$\mathrm{Na}$ Engenharia Civil são diversos os métodos aplicados visando à otimização de estruturas. Esta dissertação apresenta um estudo e uma aplicação de um desses métodos: os Algoritmos Genéticos (AG’s). Os Algoritmos Genéticos são algoritmos de busca, não-determinísticos, que trabalham com amostras do conjunto de soluções e se inspiram na teoria da evolução das espécies para resolver o problema. Neste trabalho de pesquisa buscou-se apresentar as principais técnicas e parâmetros utilizados por diversos autores neste tema. Como objetivo principal pretendeu-se, através dos conhecimentos adquiridos sobre o assunto, aplicá-lo na otimização topológica e paramétrica de vigas de concreto armado, submetidas a um carregamento distribuído. Adotaram-se restrições laterais das variáveis e comportamentais (tensões máximas admissíveis - ELU). Procurou-se trabalhar com variáveis discretas, que melhor representam a realidade do projetista de estruturas. Para aplicação desta técnica implementou-se um programa, em linguagem Java seguindo o paradigma de programação orientada a objetos. O programa foi testado aplicando-se a um problema de otimização abordado por outros autores. Um deles utilizou uma abordagem determinística para a solução do problema. Outro utilizou uma abordagem probabilística, porém com variáveis contínuas. Em 85\% dos casos o programa (nomeado AGEN) conseguiu encontrar a solução ótima. Concluiu-se que os algoritmos genéticos são uma técnica bastante robusta, que proporciona resultados significativos, principalmente quando se trata de problemas complexos, com variáveis discretas e restrições em constantes mudanças. As deficiências desta técnica são a sua grande dependência em relação à amostra inicial da população, o seu custo computacional e a calibração de parâmetros.

Procurou-se, através deste trabalho, apresentar aos pesquisadores e projetistas do campo da engenharia mais uma ferramenta que utiliza técnicas computacionais para encontrar melhores soluções para otimização de estruturas. Pretendendo-se, assim, estimular o desenvolvimento de mais pesquisas sobre este tema bastante promissor.

Palavras chave: Algoritmos Genéticos, Vigas (Otimização). 


\begin{abstract}
This work presents a study and applicattion using Genetic Algorithms (GA's) to solve problems that optmization structures, more specifically concrete beans. The GA's are search algorithms, non-deterministics that works with a population of solutions. Its inspired on the evolution's theory of the species to solve problems.

In this dissertation sought to show the most used techniques and parameters about this subject. The primary objective was (through the knowledge obtained during this research) to apply it in the topological and parametrical optimization of concrete beams, submitted by a distributed load. Lateral and behavioral constraineds are used. It was tried to work with a discrete variables, which represent more really the context of structures designer.
\end{abstract}

To apply this technique a program was implemented, using the Java language through the oriented object paradigm. The program was tested applying a optimization problem approached by other authors. One of them used a deterministic approach to solution the problem. Another used a probabilistic approach, but with continuous variable. In $85 \%$ of the cases the program (called AGEN) get success. It was concluded that genetic algorithms are a very robust technique, which provides significant results, especially in complex problems with discrete variables and constraints on dynamic changes. The weaknesses of this technique are the high dependence on initial population, its computational cost and the parameters calibration.

It was, in this work, presenting to scientists and designers in the structural engineering field another tool that uses computational techniques to find better solutions for structures optimization. It pretended to stimulate the development of more research on this topic enough promising.

Key Words: Genetic Algorithms, Beams (Optimization). 


\section{LISTA DE FIGURAS}

Figura 1 - Classificação dos Principais Métodos Determinísticos, segundo (Silva

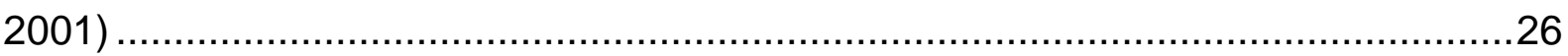

Figura 2 - Ramificações da Computação Natural, segundo (Olivieri 2004) .............27

Figura 3 - Esquema Básico de um Algoritmo Genético............................................38

Figura 4 - Analogia Genética Natural - Algoritmo Genético...................................40

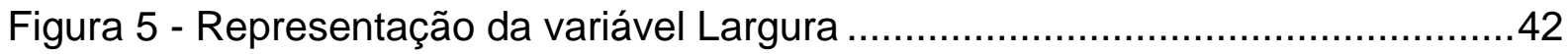

Figura 6 - Representação da variável Altura ...................................................... 43

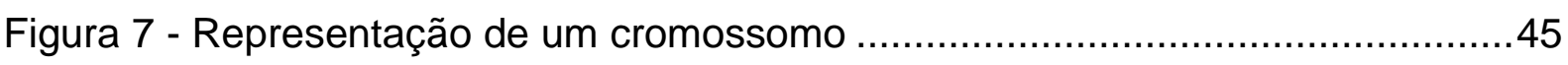

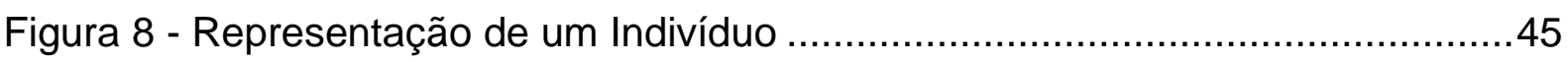

Figura 9 - Representação da Função de Aptidão ................................................46

Figura 10 - Cruzamento uniponto - Genitores.................................................52

Figura 11 - Cruzamento uniponto - Descendentes ……...................................53

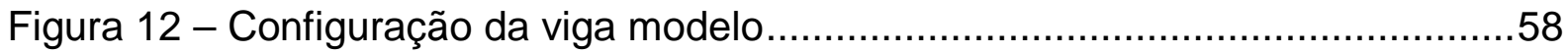

Figura 13 - Seção transversal da viga modelo ……...........................................58

Figura 14 - Seção transversal de viga sujeita a flexão ...........................................63

Figura 15 - Domínios de dimensionamento em ELU .............................................64

Figura 16 - Analogia: Problema x Algoritmo Genético..........................................66

Figura 17 - Representação do cromossomo de uma viga .......................................67

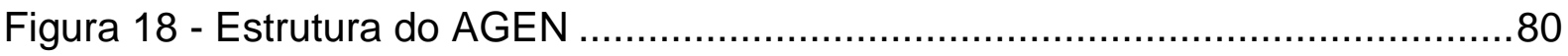

Figura 19 - Diagrama de Classes Simplificado do Pacote AG ...............................81

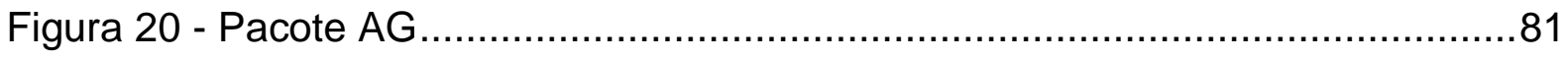

Figura 21 - Diagrama de classes simplificado do pacote Estrutura..........................83

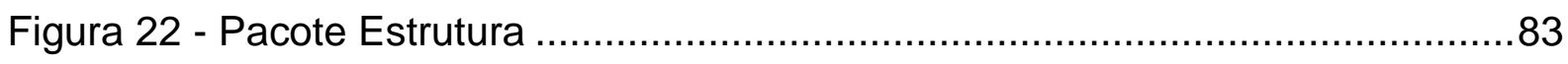

Figura 23 - Diagrama de Classes simplificado do pacote Estrutura.características .. 84

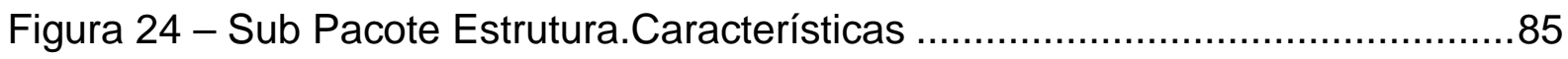

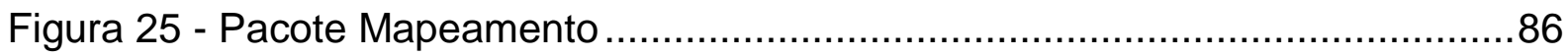

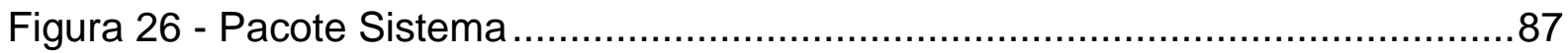

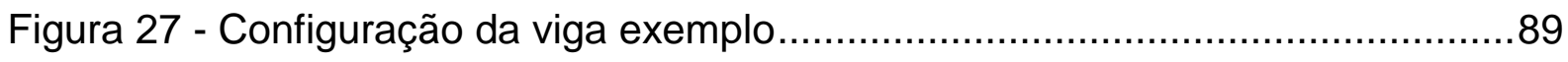

Figura 28 - Exemplo de aplicação ..................................................................106 


\section{LISTA DE GRÁFICOS}

Gráfico 1 - Probabilidade de Seleção das Vigas (Adequação em Graus) ................73

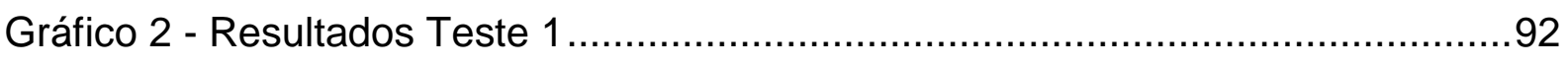

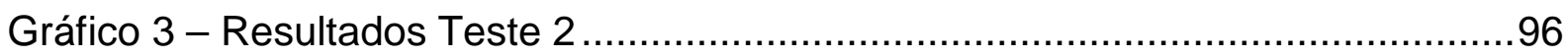




\section{LISTA DE TABELAS}

Tabela 1 - Trabalhos de Otimização Estrutural, utilizando Algoritmos Genéticos, classificados por tipo de otimização, estrutura e material. ..................................22

Tabela 2 - População X Custo Líquido X Adequação.......................................71

Tabela 3 - Adequação em graus ............................................................. 72

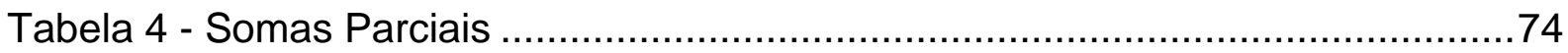

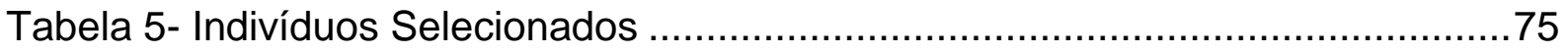

Tabela 6 - Principais pacotes e classes do AGEN .......................................... 79

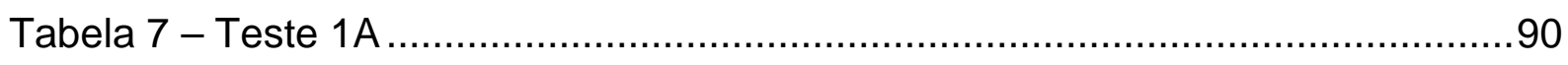

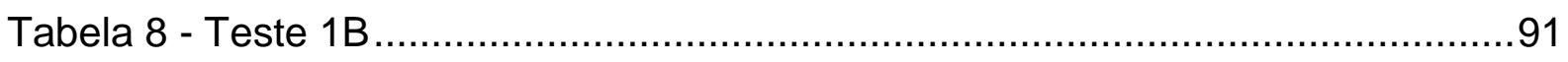

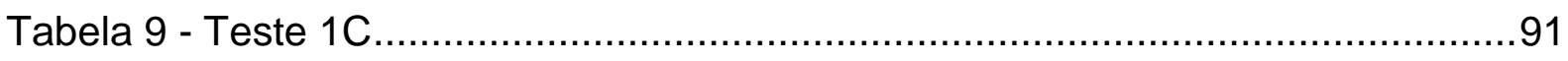

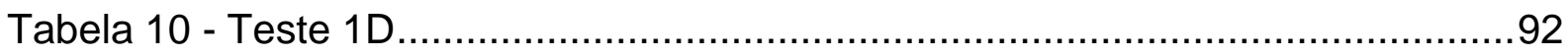

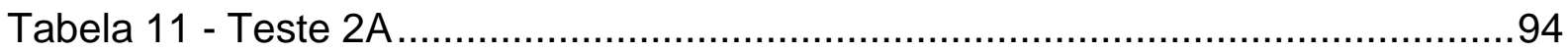

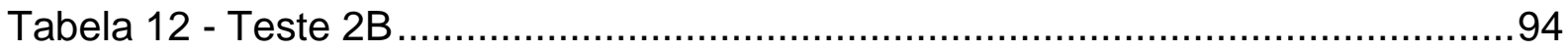

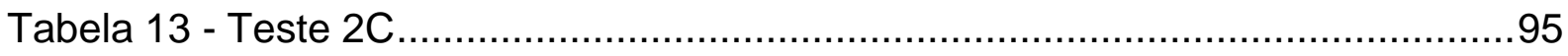

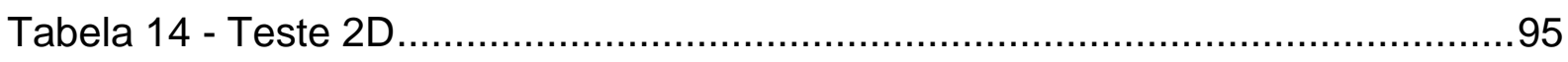




\section{SUMÁRIO}

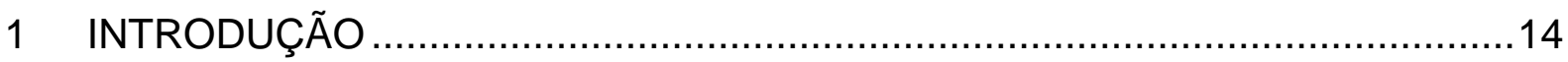

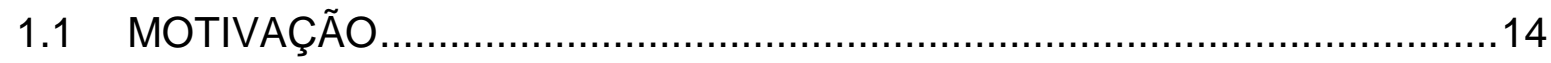

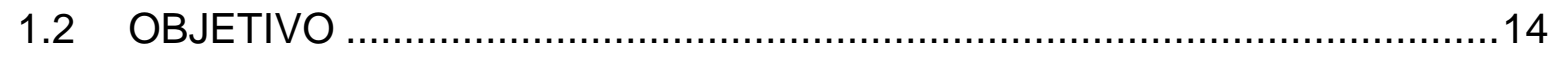

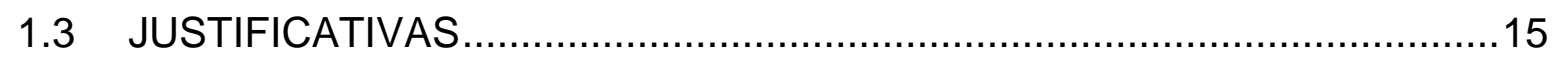

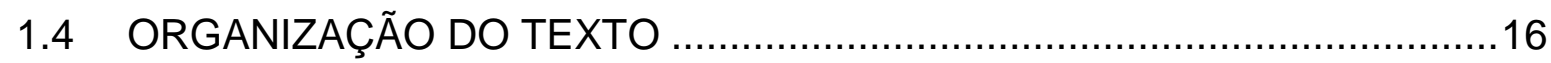

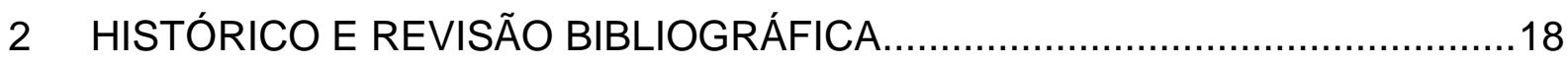

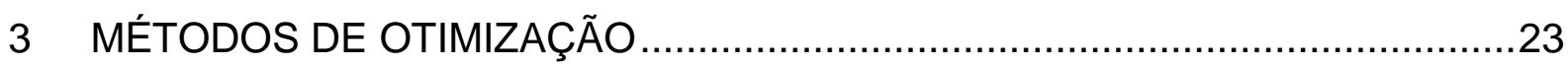

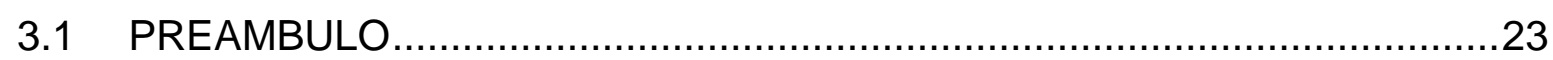

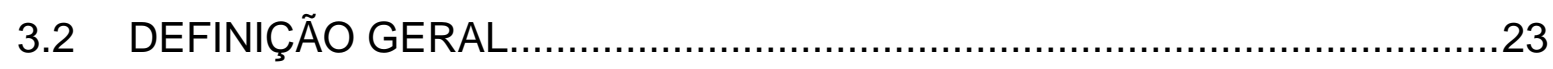

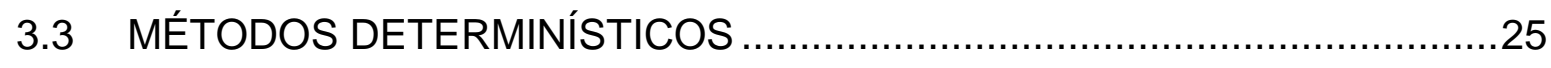

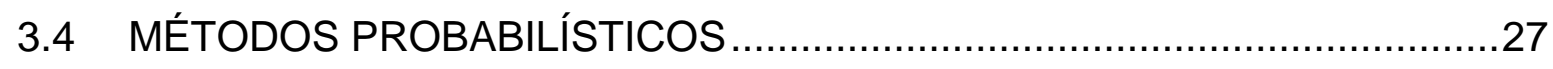

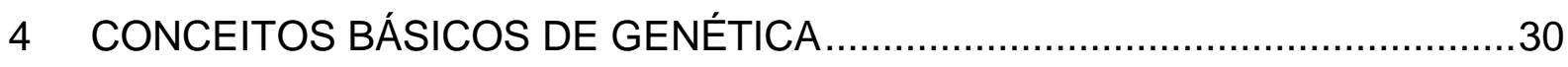

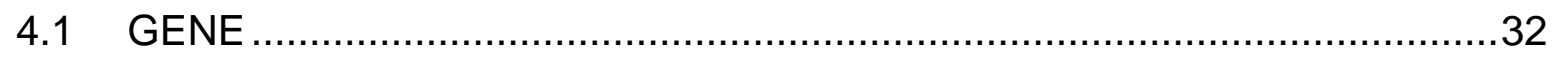

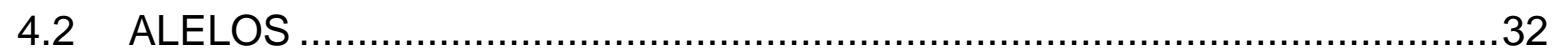

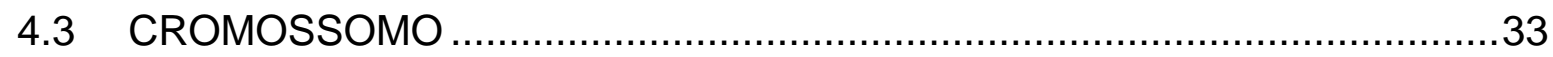

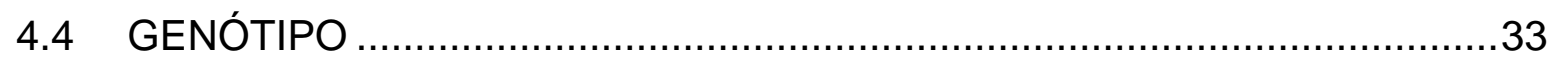

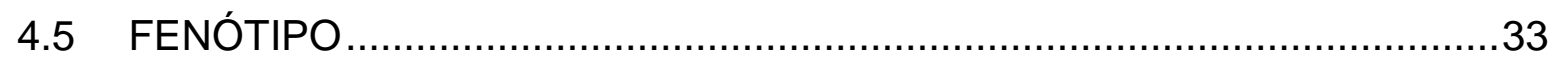

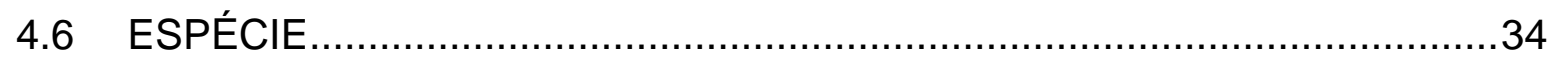

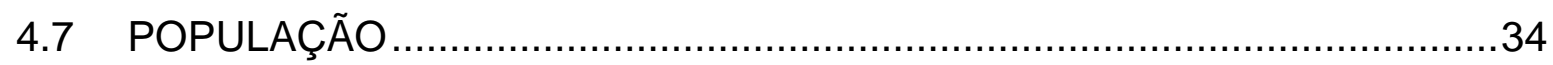

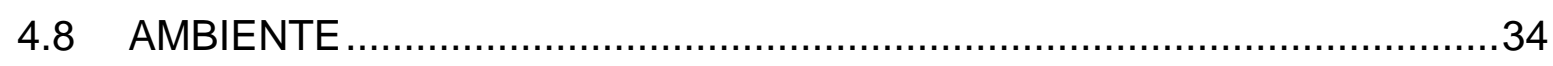

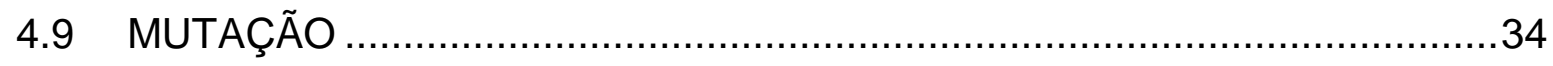

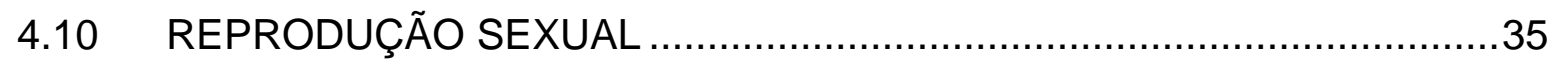

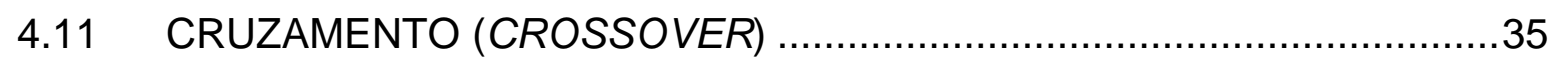

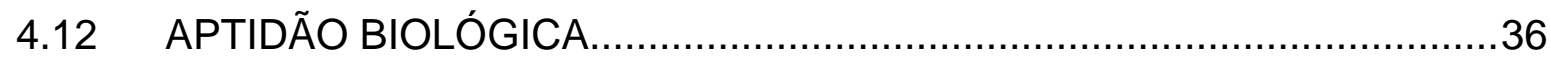




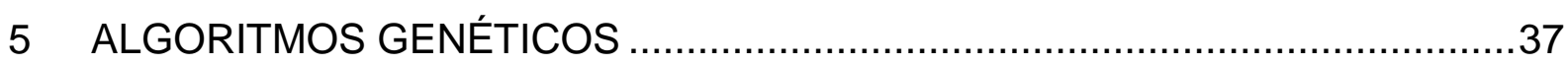

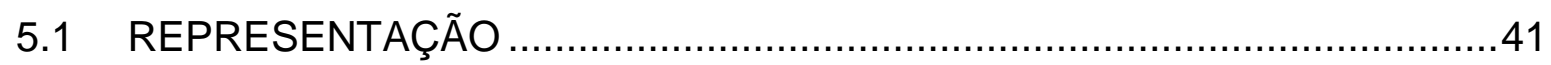

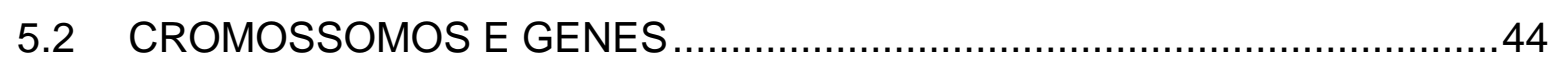

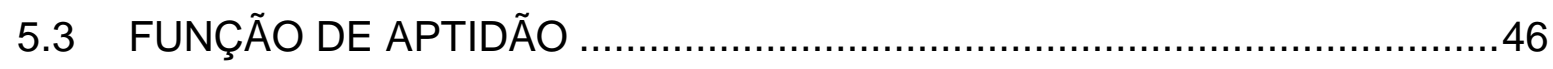

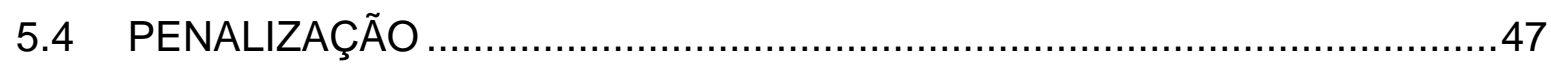

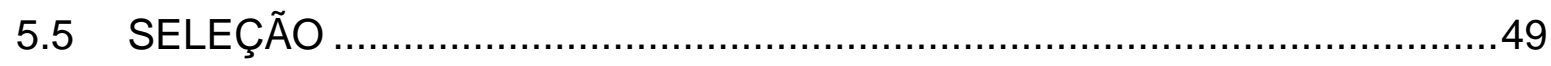

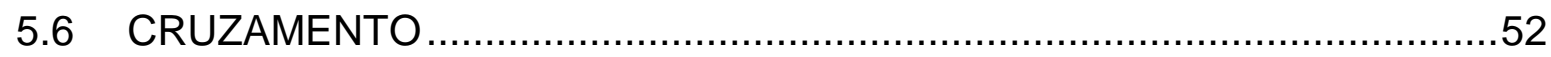

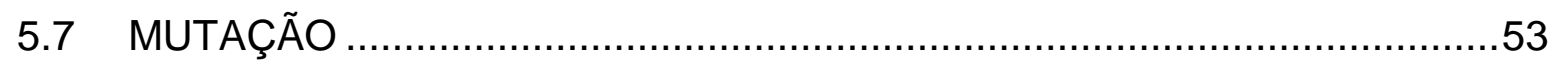

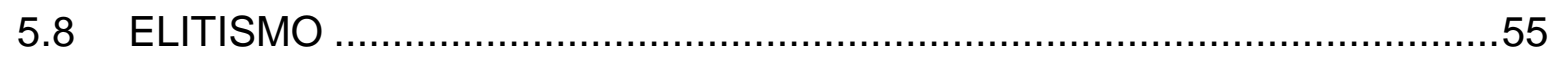

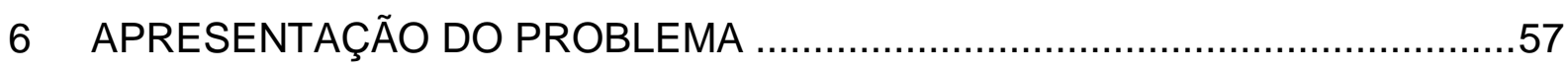

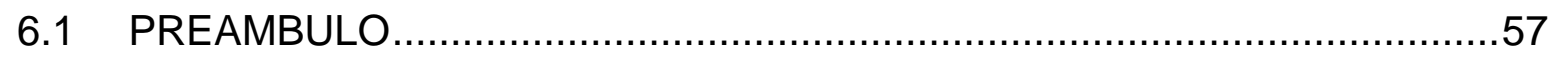

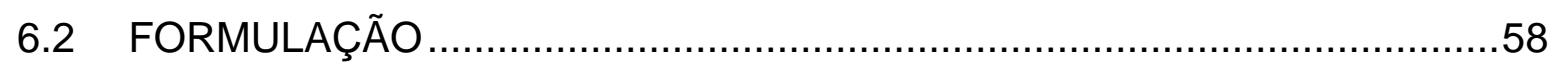

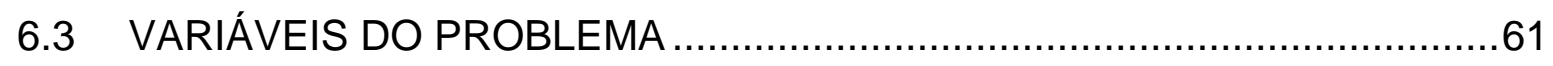

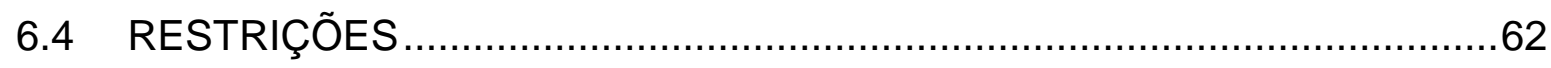

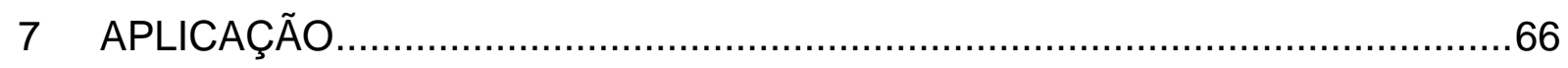

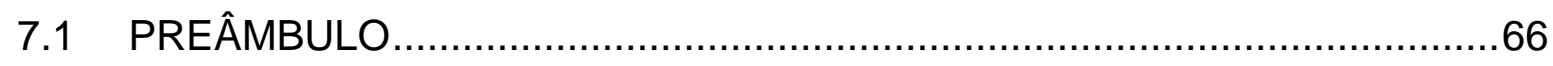

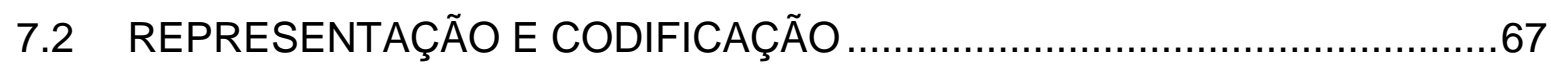

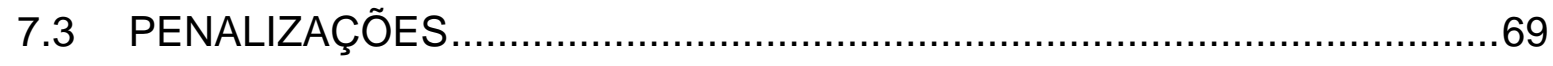

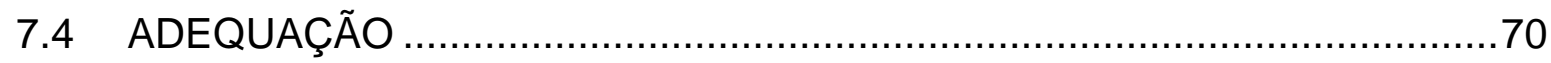

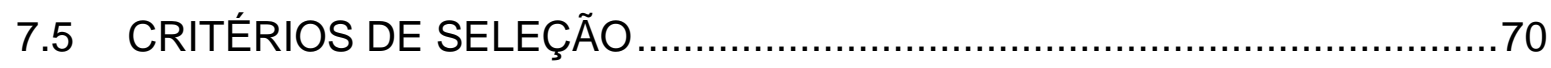

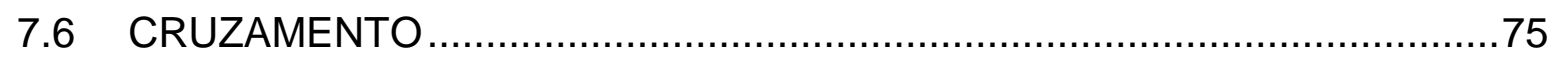

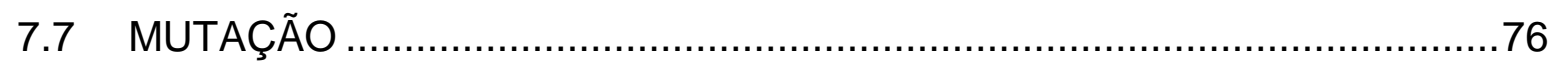

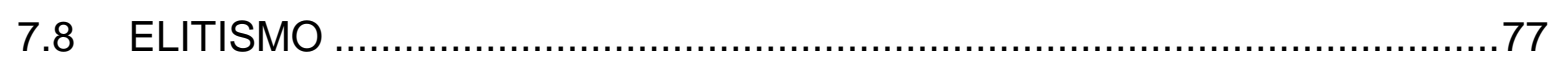

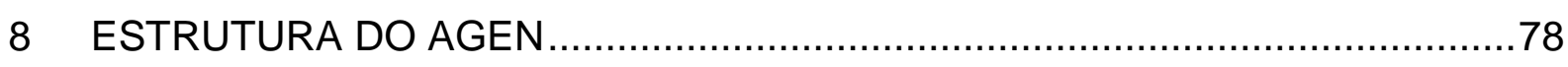

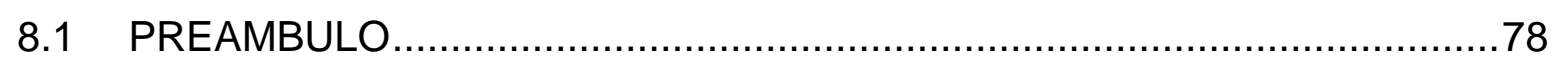

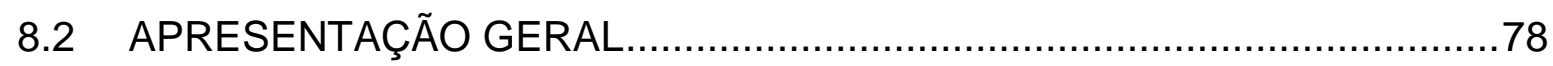

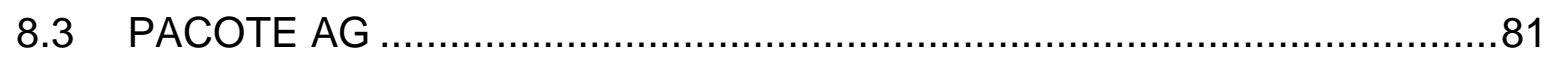




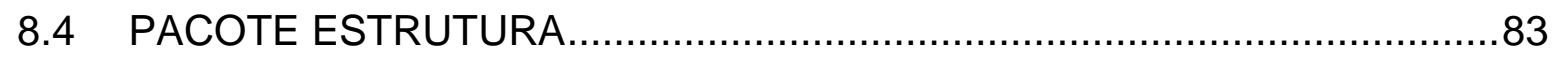

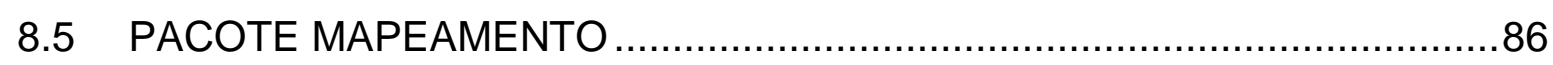

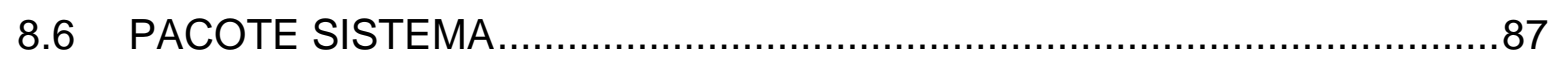

9 TESTES E CALIBRAGEM DE PARÂMETROS ….........................................88

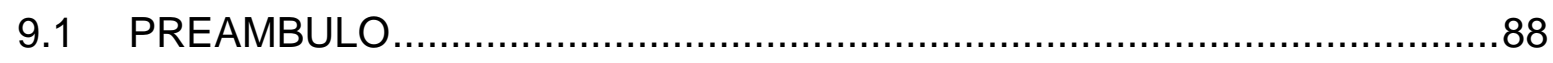

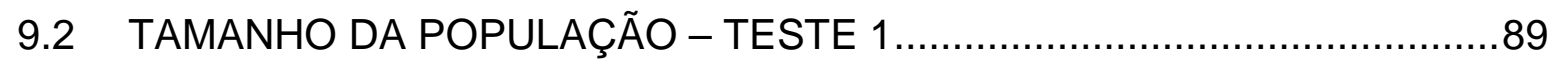

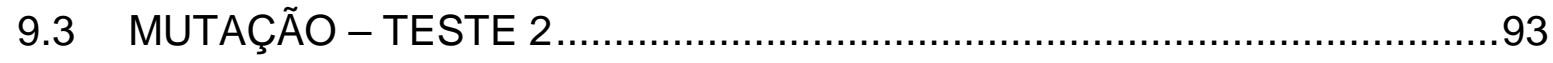

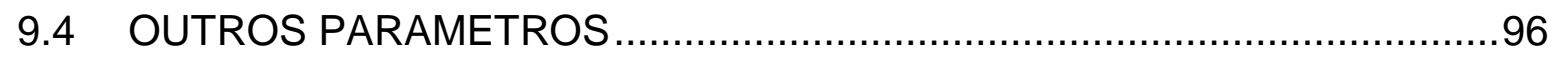

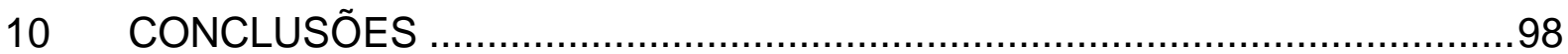

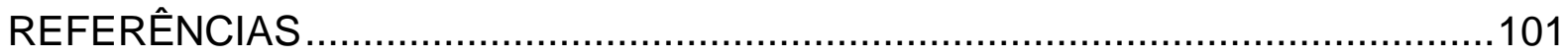

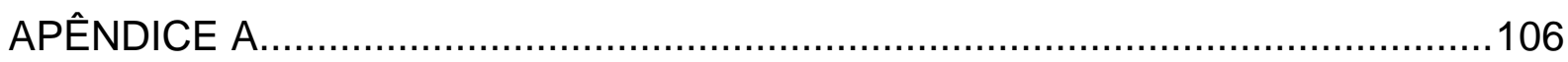

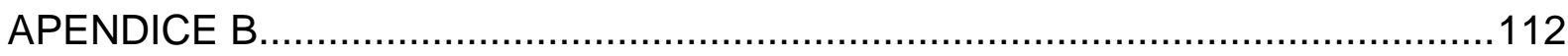




\section{INTRODUÇÃO}

\subsection{MOTIVAÇÃO}

Uma área bastante explorada na engenharia civil é no que diz respeito à busca por soluções otimizadas das estruturas. Encontrar a melhor combinação de material, seção transversal e arranjos no posicionamento dos elementos que torne o elemento estrutural o mais econômico possível.

Por ser uma ciência aplicada, a engenharia civil encontra um significativo obstáculo na aplicação das suas teorias: o seu caráter prático, que introduz restrições não concebidas em um ambiente ideal, como medidas padronizadas pelo mercado, por exemplo. Com isso, a busca se desenvolve não em torno da solução mais otimizada, e sim em busca da melhor solução, dentre as alternativas cabíveis no mercado em determinado período. E variáveis como região, disponibilidade de material e tempo também influenciam no resultado. As técnicas tradicionais de otimização necessitam de algumas informações que nem sempre é possível se obter, como por exemplo, que a função seja contínua, ou que sua primeira derivada exista. Busca-se então, outras técnicas que não necessitem destas informações e que sejam mais flexíveis e adaptáveis quanto às constantes mudanças de concepção dos projetos.

\subsection{OBJETIVO}

O principal objetivo deste trabalho é aplicar o método dos Algoritmos Genéticos na otimização topológica e paramétrica de vigas de concreto armado. Para que tal objetivo seja alcançado, faz-se necessário uma ampla busca por informações sobre o tema. Portanto, como objetivo secundário (na verdade uma mera conseqüência), procurou-se apresentar este estudo neste trabalho. 
Como os Algoritmos Genéticos são uma técnica essencialmente computacional (porém não necessariamente), procurou-se também elaborar um programa que resolvesse o problema citado anteriormente, aplicando este método, a fim de se obter experiência prática no assunto.

Portanto, os objetivos deste trabalho são:

- Elaborar um estudo sobre Algoritmos Genéticos, destacando seus principais pontos, explicando conceitos e apresentando o que vem sendo desenvolvido ao longo dos anos sobre o tema.

- Aplicar os AG's na otimização topológica e paramétrica de vigas de concreto armado, sujeitas a carregamento distribuído.

- Implementar um programa que resolva o problema citado no tópico anterior a fim de testar o método utilizado.

\subsection{JUSTIFICATIVAS}

A escolha deste tema veio da necessidade de buscar soluções otimizadas, porém práticas e exeqüíveis para o dimensionamento de vigas.

A escolha por um método baseado em heurísticas para a busca de uma solução adequada ao problema ao invés de se utilizar os demais métodos numéricos de otimização, se deve principalmente a dois fatores: o uso de variáveis discretas e 0 caráter flexível dos algoritmos genéticos. A opção por utilizar variáveis discretas ocorre do fato de, na prática, na engenharia civil trabalhar-se com materiais já determinados, com características tabeladas estabelecidas pelo mercado e pelos métodos executivos. Por exemplo, de nada adianta saber que a viga mais adequada para determinada situação deva ter $20.345 \mathrm{~cm}$ de base e $71.93 \mathrm{~cm}$ de altura. $\mathrm{Na}$ prática a seção desta viga será arredondada para $25 \mathrm{~cm}$ de base e $75 \mathrm{~cm}$ de altura. Isso vale para outros fatores que entram como variáveis no problema como bitola da armação e espaçamento dos estribos. A busca por flexibilidade no método se deve ao fato das constantes mudanças de parâmetros que ocorrem ao longo da 
concepção e execução de um projeto. Variáveis inicialmente consideradas podem ser eliminadas, enquanto outras acrescentadas sem grandes problemas. Estes fatores mudam dinamicamente e é preciso uma ferramenta de fácil adaptação para adequar as necessidades específicas e atuais de cada problema.

\subsection{ORGANIZAÇÃO DO TEXTO}

Procurou-se organizar os capítulos desta dissertação de forma a ambientar o leitor a respeito do tema de um modo gradativo e natural. Os capítulos iniciais apresentam conceitos elementares e essenciais necessários ao bom entendimento do assunto. Em seguida os conceitos e método dos Algoritmos Genéticos são apresentados de forma ampla e agregando um estudo comparativo com as diversas técnicas (dentro dos AG's) utilizadas por distintos autores no campo da engenharia de estruturas. Dando prosseguimento, o problema a ser resolvido é apresentado.

Nos últimos capítulos a aplicação que envolve o problema é apresentada com seus respectivos testes e resultados. O último capítulo apresenta as principais idéias e conclusões obtidas através desta dissertação. No apêndice é apresentada uma validação do programa implementado aplicado a um caso conhecido e tratado anteriormente por outros autores. Abaixo segue a descrição de cada capítulo desta dissertação:

No Capitulo 1 (Introdução) são introduzidos os objetivos deste trabalho bem como suas justificativas e organização do texto.

No Capítulo 2 (Revisão Bibliográfica) são apresentados os principais trabalhos nacionais e internacionais a respeito de otimização estrutural utilizando algoritmos genéticos.

No Capítulo 3 (Métodos de Otimização) são apresentados os principais tipos de otimização existentes. 
No Capítulo 4 (Conceitos Básicos de Genética) é proporcionado ao leitor um breve resumo dos principais conceitos que se deve ter sobre genética a fim de facilitar o estudo dos AG's.

No Capítulo 5 (Algoritmos Genéticos) pode-ser ver toda a teoria na qual os AG's estão baseados, bem como seus principais conceitos, operadores e funcionamento.

No Capítulo 6 (Apresentação do Problema) é exposto o problema a ser resolvido com maior riqueza de detalhes.

No capítulo 7 (Aplicação) é apresentada a aplicação do problema utilizando algoritmos genéticos.

No Capítulo 8 (Estrutura do Programa) pode-se ter uma visão geral de como o problema foi modelado no programa implementado. Apresenta as principais classes, funções e interdependência entre elas.

No Capítulo 9 (Testes e Calibragem de parâmetros) são apresentados testes realizados no programa, a fim de calibrar seus principais parâmetros e verificar sua funcionalidade.

No Capítulo 10 (Conclusão) são apresentadas as conclusões acerca deste trabalho bem com uma idéia para trabalhos futuros. 


\section{HISTÓRICO E REVISÃO BIBLIOGRÁFICA}

Em meados dos anos 50 e 60, após as descobertas que marcaram e genética moderna, muitos biólogos começaram a desenvolver simulações computacionais de sistemas genéticos. Entretanto, foi John Holland, um professor da Universidade de Michigan nos Estados Unidos, o precursor das primeiras pesquisas no tema. Holland foi refinando suas idéias ao longo dos anos e em 1975 publicou o seu livro "Adaptation in Natural and Artificial Systems". Em meados dos anos 80, um aluno de Holland chamado David Goldberg, consegue o primeiro sucesso em aplicação industrial de Algoritmos Genéticos (AG's). Desde então, estes algoritmos vêm sendo aplicados com sucesso nos mais diversos problemas de otimização e aprendizado de máquinas.

No campo da engenharia para otimização de estruturas, os AG's tem sido empregados tanto nacionalmente quanto internacionalmente, na sua maioria em estruturas metálicas.

(Cohn, et al. 1994) em 1994 apresentou um estudo com um levantamento de mais de 500 trabalhos e teses desenvolvidas a respeito de otimização estrutural. Ele organizou estes trabalhos segundo alguns critérios: grau de incerteza da abordagem utilizada (determinística ou probabilística), parâmetros e designs das variáveis envolvidas nos problemas, geometria, carregamentos, materiais e segundo a formulação do problema (restrições, função objetivo, etc).

Segundo Cohn, as publicações desde 1960 até 1994 na sua maioria tratava de otimização matemática. Ainda segundo o autor, apesar de diversas pesquisas na área de otimização estrutural existia uma distancia muito grande entre teoria e prática. $\mathrm{O}$ autor sugere que o motivo para esta distancia se deva a incontestável prioridade dada a matemática ao invés de se ater aos detalhes da otimização estrutural. Após sujeitar o problema a um simples e trivial exemplo (a fim de simplificar a formulação matemática), acaba sujeitando o sucesso da aplicação apenas para um único caso específico. No apêndice $\mathrm{B}$, no final deste trabalho, é apresentada uma tabela resumo elaborada por Cohn com a freqüência de diversos 
trabalhos de otimização estrutural organizados por algumas características básicas. Abaixo são listadas algumas conclusões obtidas através destes dados:

- $88 \%$ dos trabalhos analisados adotaram abordagem determinística enquanto que apenas $12 \%$ adotaram abordagem probabilística ${ }^{1}$.

- Dos trabalhos que adotaram abordagem probabilística, 97\% utilizaram como material o aço e apenas 3\% o concreto. Segundo (Cohn, et al. 1994) isso se deve ao fato das características (elasticidade, plasticidade e homogeneidade) do aço serem mais fáceis de modelar.

Abrindo um pequeno parêntesis, a autora desta dissertação particularmente pensa que isso se deva também ao fato do aço ser um material industrializável, portanto pode ser produzido em larga escala e com isso sua vantagem da otimização sobre uma estrutura de concreto, ainda produzida artesanalmente (apesar das estruturas pré-moldadas). Além disso, internacionalmente $o$ aço é mais utilizado que o concreto para as estruturas. Já no Brasil, como o principal material utilizado é o concreto existem mais trabalhos nesta área.

- $46 \%$ dos trabalhos probabilísticos trataram de estruturas tipo arco, $27 \%$ eram treliças planas, $10 \%$ treliças espaciais e apenas $7 \%$ barras.

- $41 \%$ dos trabalhos probabilísticos tinham como critério de restrição tanto o estado limite de serviço (ELS) quanto o estado limite último (ELU). 32\% tratava apenas do ELS e $27 \%$ apenas do ELU. É interessante comparar estes resultados com os resultados obtidos nos trabalhos que utilizaram abordagem determinística. Apenas $4 \%$ dos trabalhos que utilizaram este tipo de abordagem adotaram como critério ambos os estados limites (ELU e ELS). Acredita-se que seja pelo fato da dificuldade de acrescentar mais restrições na modelagem matemática.

Após 1994 muita pesquisa no campo de otimização estrutural utilizando AG's foi realizada. Abaixo é apresentada uma tabela com a relação de alguns dos principais

${ }^{1}$ É importante ressaltar que a pesquisa elaborada por Cohn levantou trabalhos desde 1960 a 1994. Após esse período, muita pesquisa foi produzida. 
trabalhos publicados classificados segundo o tipo de otimização, estrutura e material utilizados.

\begin{tabular}{|c|c|c|c|c|}
\hline \multicolumn{5}{|c|}{$\begin{array}{l}\text { TRABALHOS DE OTIMIZAÇÃO ESTRUTURAL, UTILIZANDO ALGORITMOS } \\
\text { GENÉTICOS }\end{array}$} \\
\hline $\begin{array}{c}\text { AUTOR (ES) / } \\
\text { ANO }\end{array}$ & $\begin{array}{l}\text { TÍTULO } \\
\text { TRABALHO }\end{array}$ & $\begin{array}{c}\text { TIPO DE } \\
\text { OTIMIZAÇÃO }\end{array}$ & $\begin{array}{c}\text { TIPO DE } \\
\text { ESTRUTURA }\end{array}$ & MATERIAL \\
\hline $\begin{array}{c}\text { (Koumousis e } \\
\text { Georgiou } \\
\text { 1994) }\end{array}$ & $\begin{array}{c}\text { "Genetic } \\
\text { Algorithm in } \\
\text { discrete } \\
\text { optimization of } \\
\text { steel truss roofs" }\end{array}$ & $\begin{array}{l}\text { Topológica e } \\
\text { Paramétrica }\end{array}$ & Vigas & Aço \\
\hline (Castro, 2001) & $\begin{array}{l}\text { "Otimização de } \\
\text { estruturas multi- } \\
\text { objetivos via } \\
\text { algoritmos } \\
\text { genéticos" }\end{array}$ & Paramétrica & $\begin{array}{l}\text { Barras e } \\
\text { treliças }\end{array}$ & Aço \\
\hline $\begin{array}{l}\text { (Cho, Min e } \\
\text { Lee 2001) }\end{array}$ & $\begin{array}{l}\text { "Optimum Life } \\
\text { Cycle cost design } \\
\text { of orthotropic } \\
\text { steel deck } \\
\text { bridges" }\end{array}$ & $\begin{array}{l}\text { Topológica e } \\
\text { Paramétrica }\end{array}$ & Grelha & Aço \\
\hline $\begin{array}{l}\text { (Deb e Gulati } \\
\quad 2001 \text { ) }\end{array}$ & $\begin{array}{l}\text { "Design of truss } \\
\text { structures for } \\
\text { minimum weight } \\
\text { using Genetic } \\
\text { Algorithm" }\end{array}$ & $\begin{array}{l}\text { Topológica e } \\
\text { Paramétrica }\end{array}$ & Treliça & Aço \\
\hline $\begin{array}{l}\text { (Castilho } \\
2003)\end{array}$ & $\begin{array}{l}\text { "Otimização de } \\
\text { componentes de } \\
\text { concreto pré- } \\
\text { moldado } \\
\text { protendido } \\
\text { mediante } \\
\text { algoritmos } \\
\text { genéticos" }\end{array}$ & Paramétrica & Lajes & Concreto \\
\hline $\begin{array}{l}\text { (Pizzirani } \\
2003)\end{array}$ & $\begin{array}{l}\text { "Otimização de } \\
\text { estruturas } \\
\text { utilizando } \\
\text { Algoritmos } \\
\text { Genéticos" }\end{array}$ & Paramétrica & Vigas & Concreto \\
\hline
\end{tabular}




\begin{tabular}{|c|c|c|c|c|}
\hline $\begin{array}{c}\text { AUTOR (ES) / } \\
\text { ANO }\end{array}$ & $\begin{array}{l}\text { TÍTULO } \\
\text { TRABALHO }\end{array}$ & $\begin{array}{c}\text { TIPO DE } \\
\text { OTIMIZAÇÃO }\end{array}$ & $\begin{array}{c}\text { TIPO DE } \\
\text { ESTRUTURA }\end{array}$ & MATERIAL \\
\hline (Silva 2001) & $\begin{array}{l}\text { "Otimização de } \\
\text { Estruturas de } \\
\text { Concreto Armado } \\
\text { utilizando } \\
\text { Algoritmos } \\
\text { Genéticos" }\end{array}$ & Paramétrica & $\begin{array}{c}\text { Pilares e } \\
\text { Pórtico Plano }\end{array}$ & Concreto \\
\hline $\begin{array}{c}\text { (Sakla e } \\
\text { Elbeltagi } \\
2003 \text { ) }\end{array}$ & $\begin{array}{l}\text { "Design of Steel } \\
\text { Roofs Subjected } \\
\text { to Drifted Snow } \\
\text { using Genetic } \\
\text { Optimization" }\end{array}$ & $\begin{array}{l}\text { Topológica e } \\
\text { Paramétrica }\end{array}$ & Vigas & Aço \\
\hline $\begin{array}{l}\text { (Croce, } \\
\text { Ferreira e } \\
\text { Lemonge } \\
2004)\end{array}$ & $\begin{array}{l}\text { "A Genetic } \\
\text { Algorithm for } \\
\text { Structural } \\
\text { Optimization of } \\
\text { steel Truss Roof" }\end{array}$ & $\begin{array}{l}\text { Topológica e } \\
\text { Paramétrica }\end{array}$ & Treliça & Aço \\
\hline $\begin{array}{l}\text { (Kicinger e } \\
\text { Arciszewski } \\
\text { 2004) }\end{array}$ & $\begin{array}{l}\text { "Evolutionary } \\
\text { Multiobjetive } \\
\text { Optmization of } \\
\text { Steel Structural } \\
\text { Systems in tall } \\
\text { buildings " }\end{array}$ & $\begin{array}{l}\text { Topológica e } \\
\text { Paramétrica }\end{array}$ & Pórtico Plano & Aço \\
\hline (Olivieri 2004) & $\begin{array}{l}\text { "Otimização de } \\
\text { projeto de pontes } \\
\text { protendidas pré- } \\
\text { moldadas pelo } \\
\text { método dos } \\
\text { Algoritmos } \\
\text { Genéticos" }\end{array}$ & Paramétrica & Vigas & Concreto \\
\hline $\begin{array}{l}\text { (Del Savio, et } \\
\text { al. 2005) }\end{array}$ & $\begin{array}{l}\text { "Genetic } \\
\text { Algorithm } \\
\text { optimization of } \\
\text { semi-rigid steel } \\
\text { structures" }\end{array}$ & Paramétrica & Pórtico Plano & Aço \\
\hline $\begin{array}{l}\text { (Gantovnik } \\
\text { 2005) }\end{array}$ & $\begin{array}{l}\text { "Na Improved } \\
\text { Genetic Algorithm } \\
\text { of Composite } \\
\text { Structures" }\end{array}$ & Paramétrica & Vigas & Aço \\
\hline
\end{tabular}




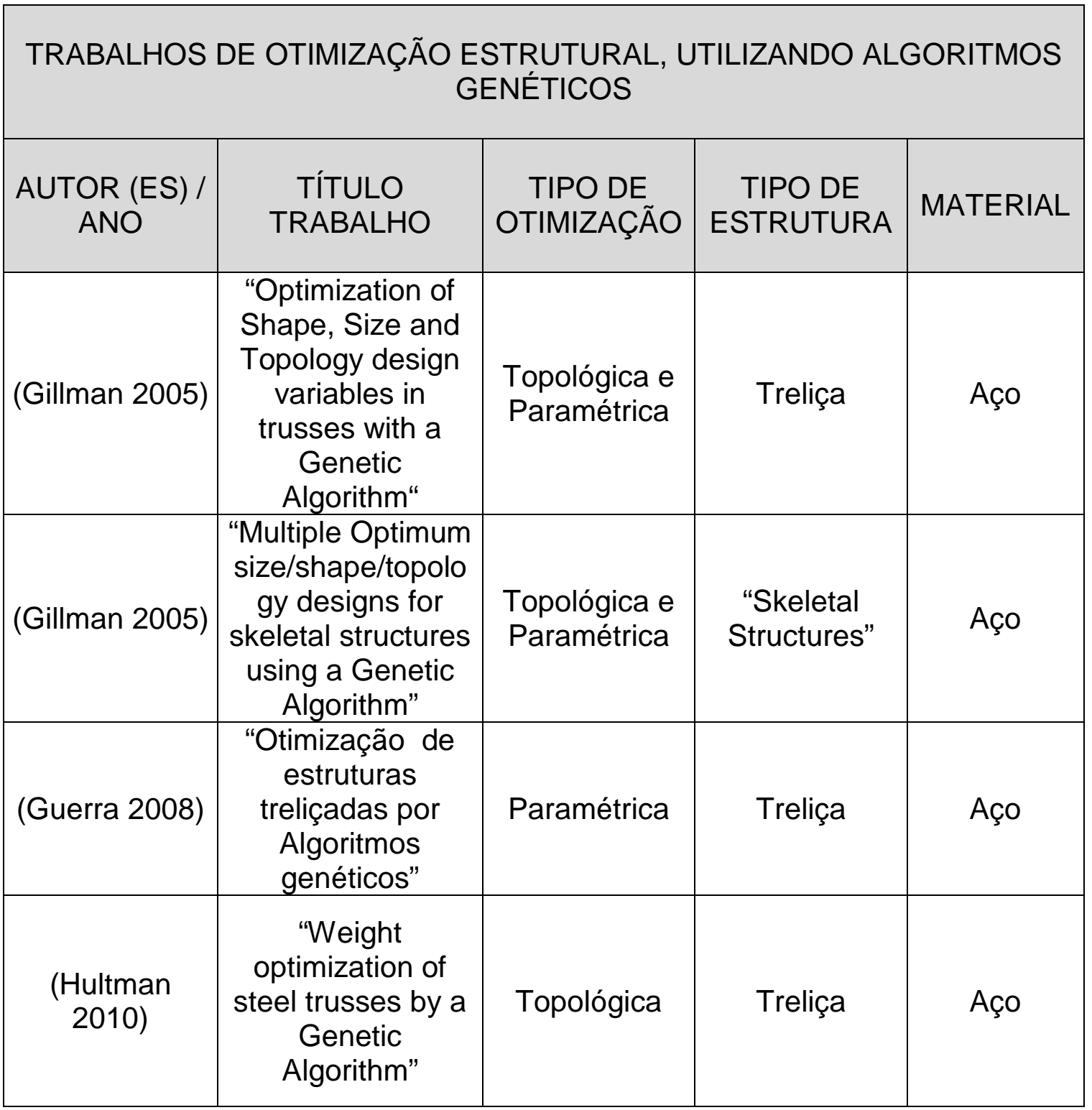

Tabela 1 - Trabalhos de Otimização Estrutural, utilizando Algoritmos Genéticos, classificados por tipo de otimização, estrutura e material.

Dos trabalhos listados, $77 \%$ utilizaram como material o aço. Apenas $23 \%$ trabalharam com concreto (todos de pesquisadores brasileiros). Nota-se que ainda existe uma predileção pelo aço como material, mas também não se pode ignorar que o concreto vem ganhando cada vez mais espaço. A otimização estrutural utilizando Algoritmos Genéticos ainda não é uma técnica abordada pela maioria dos pesquisadores, em parte devido ao seu caráter probabilístico. Porém, espera-se que, com o desenvolvimento de mais pesquisas na área, alguns "preconceitos" possam ser quebrados e com isso desenvolver mais este campo. 


\section{MÉTODOS DE OTIMIZAÇÃO}

\subsection{PREAMBULO}

Este capítulo apresenta uma síntese dos principais métodos de otimização existentes. Estes métodos são apenas citados e classificados segundo algum critério, de forma a situar o leitor da posição global em que se encontra o método de otimização que será adotado neste trabalho (os Algoritmos Genéticos), ou seja, para que se possa ter uma melhor percepção do enquadramento deste tipo de algoritmo com relação aos demais métodos existentes. Para maiores detalhes sobre métodos de otimização é aconselhável ler a bibliografia, sugerida no final de cada tópico deste capítulo. Os AG's (objeto de estudo deste trabalho) serão tratados com mais detalhes em um capítulo específico.

\subsection{DEFINIÇÃO GERAL}

No dicionário, otimizar significa: "Dar a algo (uma máquina, uma empresa) um rendimento ótimo, criando-lhe as condições mais favoráveis ou tirando (dele ou dela) o melhor partido possível; tornar (algo) ótimo ou ideal"

Traduzindo para uma linguagem matemática, os problemas de otimização são geralmente problemas de maximização ou minimização de uma função de uma ou mais variáveis pertencentes a um dado domínio, sujeitas ou não a determinadas restrições. Estas restrições podem ser expressas por equações, inequações ou simplesmente limites superior e inferior das variáveis. Fundamentalmente um problema de otimização pode ser definido conforme segue abaixo: 
Seja $\quad f: \mathbb{R}^{m} \rightarrow \mathbb{R}, g: \mathbb{R}^{m} \rightarrow \mathbb{R}^{q}, h: \mathbb{R}^{m} \rightarrow \mathbb{R}^{p}$

Minimizar/Maximizar: $f\left(\mathrm{x}_{1}, \mathrm{x}_{2}, \mathrm{x}_{3}, \ldots, \mathrm{x}_{\mathrm{n}}\right)$

Sujeito a:

$h_{k}(\mathrm{x} 1, \mathrm{x} 2, \mathrm{x} 3, \ldots, \mathrm{xn})=0 \quad k \in\{1, \ldots, p\}$ (Restrições de igualdade - Equações)

$g_{j}(\mathrm{x} 1, \mathrm{x} 2, \mathrm{x} 3, \ldots, \mathrm{xn}) \leq 0 \quad j \in\{1, \ldots, q\}$ (Restrições de Desigualdade - Inequações)

Sendo $\mathrm{x} 1, \mathrm{x} 2, \mathrm{x} 3, \ldots, \mathrm{xn}$ as variáveis do problema.

Os problemas de otimização podem ser classificados segundo o grau de relação entre as variáveis tanto na função objetivo quanto nas restrições. Sendo classificados como lineares aqueles problemas em que as variáveis variam linearmente em relação à função objetivo e/ou em relação às restrições $e$, conseqüentemente, são considerados não-lineares os problemas em que elas variam de uma forma não linear seja na função objetivo, nas restrições ou em ambos.

Os problemas também podem ser classificados segundo a presença ou não de restrições. São considerados não restringidos quando não possuem restrições, e restringidos quando possuem restrições.

(Zuben 2004) distingue os métodos de otimização em três categorias, classificadas de acordo com seu grau de rigidez em relação ao grupo de problemas abordados. Segundo (Zuben 2004):

- Métodos Fortes: São idealizados para resolverem problemas genéricos, porém são desenvolvidos para operarem em um ambiente específico, onde a linearidade, continuidade e/ou estacionariedade devem prevalecer. São considerados exemplos de métodos fortes o método dos gradientes e técnicas de programação linear.

- Métodos Específicos: São idealizados para resolverem problemas específicos em ambientes específicos. Por exemplo, uma técnica que conduz a uma solução na forma fechada, exclusiva apenas para aquele determinado problema. 
- Métodos Fracos: São idealizados para resolverem problemas genéricos em ambientes genéricos. "Operam em mundos não-lineares e não estacionários, embora não garantam eficiência total na obtenção da solução" (Zuben 2004). São exemplos de métodos fracos os Algoritmos Genéticos.

No campo da engenharia de estruturas, os problemas de otimização podem ser classificados também segundo o critério de otimização:

- Otimização topológica - refere-se, em meios discretos como barras, treliças e pórticos, a uma otimização de layout. Ou seja, é uma otimização que busca encontrar o melhor arranjo entre nós e posicionamento dos elementos.

- Otimização Paramétrica - corresponde à otimização de parâmetros do elemento analisado. Esses parâmetros podem ser relacionados a características constitutivas do elemento (material, módulo de elasticidade, etc.) como também características geométricas (dimensões de base, altura, espessura, etc.).

- Otimização de forma - algumas vezes confundida com a paramétrica, permite alterar a forma da estrutura de maneira a encontrar a solução ótima.

De uma maneira geral existem duas vertentes de métodos de otimização:

- Métodos determinísticos e

- Métodos probabilísticos.

\subsection{MÉTODOS DETERMINÍSTICOS}

Os métodos determinísticos se baseiam em um conjunto de ações sistemáticas e uso de teoremas que irão determinar um resultado que, se não é o ótimo, pelo menos será bastante próximo do mesmo, com certo grau de precisão. Os métodos determinísticos geralmente utilizam de pelo menos a primeira derivada da função objetivo em relação às variáveis de projeto e, por isso a importância da função ser contínua e derivável. 
Eles funcionam melhor para variáveis contínuas. Quando se trata de problemas de variáveis discretas é preciso tratar o resultado para que se consiga a restrição desejada.

Em seu trabalho (Silva 2001) organizou uma classificação geral de uma vasta gama de métodos determinísticos existentes, como se pode observar a seguir:

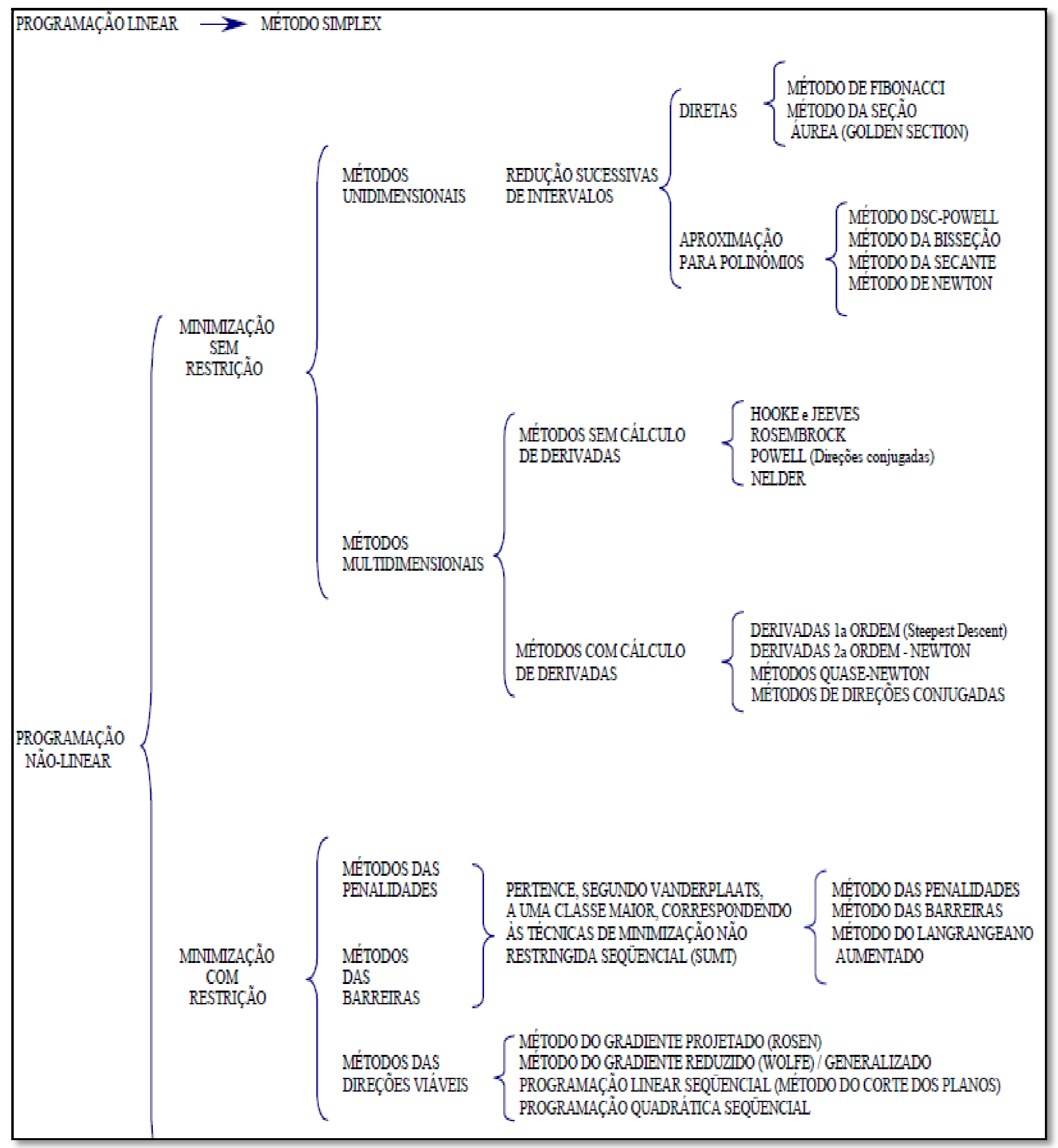

Figura 1 - Classificação dos Principais Métodos Determinísticos, segundo (Silva 2001) 
Para um estudo mais aprofundado sobre métodos determinísticos de otimização sugere-se os livros: "Linear and Nonlinear Programming" (Luenberger 2003) e "Elements of Structural Optimization" (Haftka e Gurdal 1991).

\subsection{MÉTODOS PROBABILÍSTICOS}

Os métodos probabilísticos, como o próprio nome diz, se baseiam em análises probabilísticas das possíveis soluções para um determinado problema. Enquanto nos métodos determinísticos o resultado está completamente determinado pelos procedimentos que o precedem e condiciona com o mesmo valor os procedimentos que o sucedem, nos métodos probabilísticos a relação de causa e efeito não é completamente determinada. Pode-se apenas determinar a probabilidade de ocorrência de um dado fenômeno a partir do conhecimento dos que o precedem. (Olivieri 2004) define da seguinte forma este tipo de método de otimização: "técnicas que imitam, de forma simplificada, fenômenos ou processos encontrados na natureza e, por esse motivo, denominadas de Computação Natural". Em seu trabalho Olivieri apresenta as ramificações desta chamada "Computação Natural":

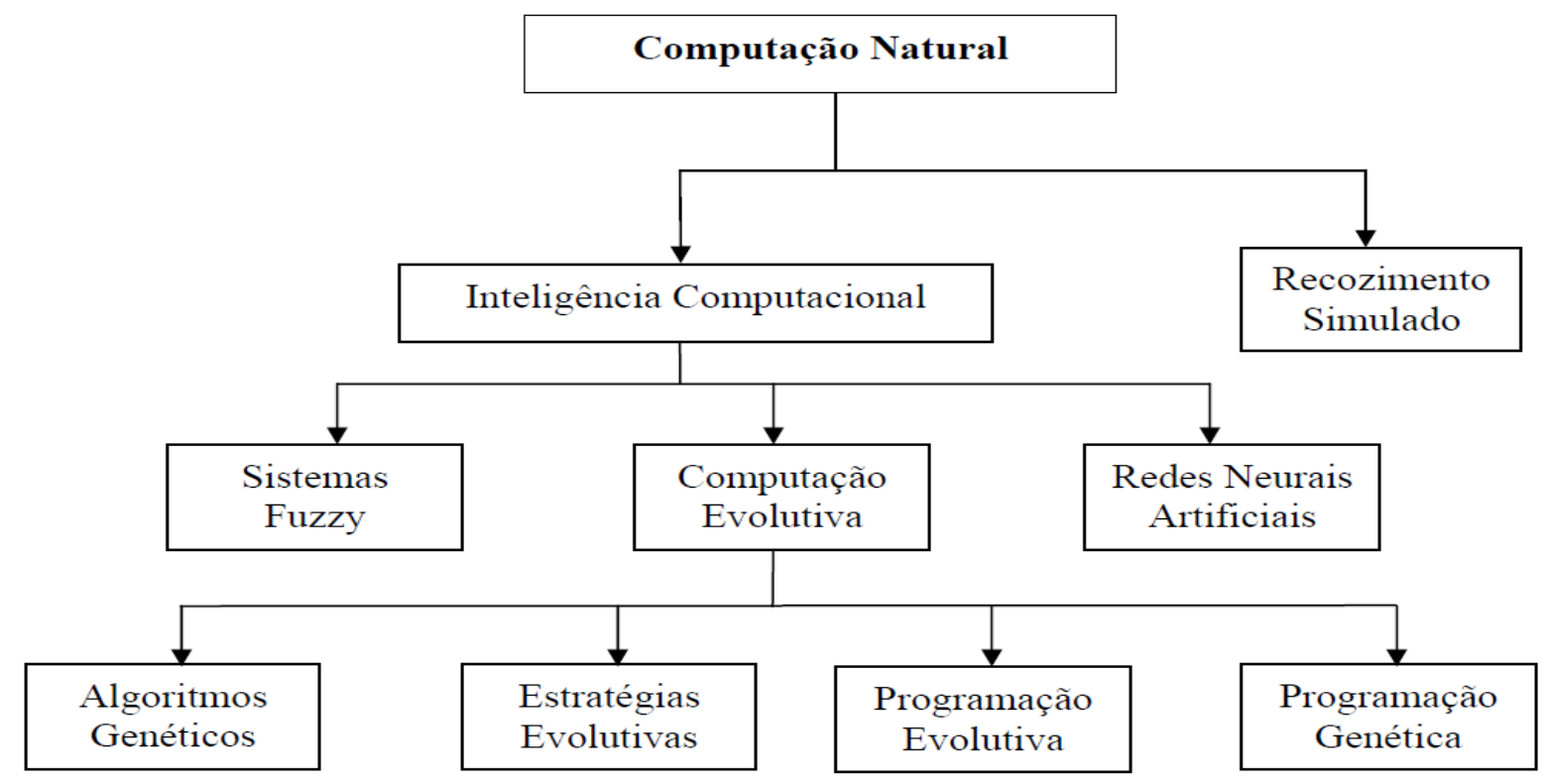

Figura 2 - Ramificações da Computação Natural, segundo (Olivieri 2004) 
Como se pode perceber os Algoritmos Genéticos (objeto de estudo deste trabalho) fazem parte de um grupo chamado Computação Evolutiva, em que se inspiram na teoria da evolução das espécies para resolver problemas.

A Computação Evolutiva surgiu em meados dos anos 50. Porém durante quase 30 anos ficou estagnada, devido à falta de computadores eficientes na época. Apenas após os trabalhos de Holland e outros pesquisadores (em meados dos anos 70) é que a computação evolutiva voltou e se desenvolveu, sendo utilizada cada vez mais.

As diferenças entre esses algoritmos são sutis, porém significantes. Os Algoritmos Genéticos empregam operadores de crossover e mutação. Koza (1992) fez uma adaptação dos AG's de forma a aplicá-los na evolução de programas de computador, o que ficou denominado de Programação Genética. As Estratégias Evolutivas diferem dos AG's por utilizarem apenas mutação para resolver problemas de otimização. Já a Programação Evolutiva também emprega apenas a mutação e foi originalmente proposta por Fogel et. al. (1996) com a finalidade de criar inteligência artificial, através da evolução de máquinas de estado finito.

Todos os métodos evolucionários (baseados na computação evolutiva) possuem duas características que os distinguem dos demais algoritmos de busca:

- São totalmente baseados em populações;

- Há uma troca de informações entre os indivíduos e a população como um todo. Esta troca de informações é um resultado de operações como seleção, recombinação e mutação.

(BASTOS, 2004) cita algumas das características dos métodos evolucionários:

- Não requerem que a função objetivo seja contínua ou diferenciável;

- Trabalham adequadamente, tanto com parâmetros contínuos quanto com discretos, ou ainda com uma combinação deles;

- Não necessitam de formulações complexas ou reformulações para o problema;

- Não há restrição alguma quanto ao ponto de partida dentro do espaço de busca da solução; 
- Realizam buscas simultâneas no espaço de possíveis soluções através de uma população de indivíduos;

- Otimizam um grande número de variáveis, desde que a avaliação da função objetivo não tenha um custo computacional demasiadamente alto.

- A maior desvantagem em relação aos métodos clássicos é o tempo de processamento.

Para um estudo mais detalhado sobre Computação Evolutiva, sugere-se consultar a bibliografia. Entre os autores que se destacam no tema estão: (BÄCK, HAMMEL e SCHWEFEL 1997), (Michalewicz e Hinterding 1997), (Goldberg 1989) e (Holland 1975). 


\section{CONCEITOS BÁSICOS DE GENÉTICA}

Genética é o ramo da biologia que estuda a forma como se dá a transferência das características dos seres vivos de geração para geração. Um dos primeiros pesquisadores a tratar do assunto foi o naturalista francês Lamark. Segundo Lamark o princípio evolutivo estaria baseado em duas leis fundamentais: Lei do uso e desuso e Lei de transmissão dos caracteres adquiridos.

- Lei do uso ou desuso: a constante utilização de determinadas partes do corpo do organismo fazia com que elas se desenvolvessem mais do que as outras e vice versa, ou seja, o fato do seu desuso causaria atrofiação.

- Lei da transmissão dos caracteres adquiridos: alterações provocadas em determinadas características do organismo, pelo uso e desuso, são transmitidas aos descendentes.

Hoje se sabe que a teoria de Lamark não é válida, pelo menos não em sua totalidade, porém foi muito importante, pois abriu o caminho para as pesquisas nesta área. Outro pesquisador, que não se pode deixar de citar é Mendel, um monge austríaco, considerado por muitos o verdadeiro pai da genética. Mendel, através de seu trabalho no cruzamento de ervilhas, observou que as condições do tempo, do solo e da umidade afetavam as características do crescimento das plantas, porém eram os fatores hereditários os maiores responsáveis pelas suas características. Foi um passo fundamental para o avanço da genética (apesar de, na época, esse termo "genética" ainda não existir). Quase que ao mesmo tempo das descobertas de Mendel, um naturalista inglês chamado Charles Darwin conseguiu organizar e catalogar informações relevantes que viriam a favorecer a sua pesquisa sobre a origem da vida. Em 1859, com seu livro intitulado: "A Origem das espécies", Darwin procurou elucidar, dentre outras coisas, o funcionamento da vida, explicando as transformações dos seres vivos ao longo do tempo e o porquê de certas espécies terem se extinguido.

Segundo Darwin, as espécies de todos os seres vivos que conhecemos hoje são resultado de uma evolução de milhões de anos. Ele introduz o conceito de seleção 
natural para explicar a sobrevivência e predominância de umas espécies sobre as outras. Resumidamente sua teoria explica que somente as espécies mais preparadas é que irão sobreviver as adversidades do meio em que vivem. As espécies que não possuírem características que permitam suportar as adversidades irão morrer jovens (antes de atingirem maturidade para a reprodução) e com isso não conseguirão perpetuar a espécie, causando assim sua extinção. A esse processo Darwin nomeou de "Seleção Natural". Para que essa teoria funcione, estas características biológicas que vem a tornar um indivíduo mais apto que outros devem ser hereditários, ou seja, devem ser transmitidas de geração para geração.

Abaixo segue um resumo das principais idéias da teoria de Darwin:

- Todo organismo tem grande capacidade de reprodução, produzindo muitos descendentes. Entretanto, apenas alguns dos descendentes chegam à idade adulta.

- Indivíduos de uma mesma espécie possuem características diferentes, não sendo, portanto, idênticos entre si.

- Devido ao fato de só alguns indivíduos conseguirem chegar à vida adulta (idade para a reprodução), existe uma "batalha" pela vida entre os descendentes.

- Nesta "batalha" pela vida, indivíduos com características mais favoráveis as condições do ambiente possuem maiores chances de sobreviver, quando comparados aos indivíduos ou organismos com características menos favoráveis.

- Organismos com estas variações favoráveis conseguem transmitir suas características para os seus descendentes. Assim, ao longo das gerações, a atuação da seleção natural sobre os indivíduos mantém ou melhora o grau de adaptação destes ao meio.

No inicio do século $X X$, devido aos avanços nas pesquisas no campo da genética, os cientistas fizeram várias descobertas, criando-se, assim, uma nova teoria baseada nos princípios da seleção natural, essa teoria híbrida é comumente chamada de neodarwinismo, pois se baseia no modelo de Darwin, porém consegue 
explicar melhor fenômenos como a variabilidade das populações, mutações, entre outros.

A seguir serão apresentados alguns conceitos básicos de genética e da teoria da seleção natural. Procurou-se ser sucinto na explicação destes conceitos, servindo apenas como base para um melhor entendimento do capítulo que se segue sobre Algoritmos Genéticos. Para um estudo mais aprofundado sobre genética aconselhase o livro "The Science of Genetics" de (Atherly, Girton e McDonald. 1998).

\subsection{GENE}

O gene é a unidade básica da hereditariedade. Ele é formado por uma seqüência específica de ácidos nucléicos. Os ácidos nucléicos são biomoléculas fundamentais para a formação da estrutura celular. Eles contêm o "código da vida", ou seja, a informação necessária para o funcionamento do organismo. Sendo assim, os genes não só controlam a estrutura e as funções metabólicas das células; quando localizados em células reprodutivas eles são capazes de transmitir suas informações para os demais descendentes.

\subsection{ALELOS}

Os alelos são formas alternativas de um mesmo gene. Por exemplo, no homem, temos um gene que determina a cor dos olhos. Este gene pode ser um que determine a cor castanho, a cor verde ou a cor azul, por exemplo. A estes genes, que determinam uma dada característica em comum, chamamos de alelos. 


\subsection{CROMOSSOMO}

O cromossomo é constituído por uma longa fita dupla de DNA. O DNA é o material que constitui os genes. Ou seja, o cromossomo é o pacote que contem um determinado agrupamento de genes. Toda espécie possui um número definido de cromossomos e eles estão contidos no núcleo de todas as células do organismo. Os cromossomos encontram-se organizados em pares, a estes pares de cromossomos com genes de características similares (alelos) chamamos de cromossomos homólogos. A espécie humana possui 46 cromossomos, ou seja, 23 pares de cromossomos.

\subsection{GENÓTIPO}

O genótipo é a constituição genética de um indivíduo, ou seja, é o conjunto de genes que um indivíduo possui.

\subsection{FENÓTIPO}

O fenótipo é o conjunto de características apresentadas por um indivíduo sejam elas morfológicas, fisiológicas ou comportamentais. Ou seja, são suas características manifestas, estejam elas visíveis ou não, como por exemplo, cor da pele, cor dos olhos, tipo de cabelo, traços da personalidade. O fenótipo é um resultado das informações contidas no genótipo. Nem todas as informações do genótipo se apresentam fisicamente no indivíduo, apenas as que irão se manifestar é o que é chamado de fenótipo. 


\subsection{ESPÉCIE}

Grupo de indivíduos com características semelhantes capazes de se reproduzir e gerar descendentes férteis. Indivíduos de espécies diferentes geralmente não se cruzam ou por falta de condições anatômicas ou por desinteresse sexual. Quando ocorre um cruzamento com indivíduos de diferentes espécies eles raramente geram descendentes, pois possuem uma estrutura genética incompatível, ou seja, seus cromossomos não formam pares. Quando conseguem gerar seus descendentes, estes são inférteis.

\subsection{POPULAÇÃO}

Grupo de indivíduos de uma mesma espécie que habitam determinado ambiente em um mesmo período de tempo.

\subsection{AMBIENTE}

É o conjunto de condições, leis, influências e infra-estrutura de ordem física, química e biológica, que permite, abriga e rege a vida em todas as suas formas.

\subsection{MUTAÇÃO}

É uma alteração definitiva no material genético de um determinado organismo. Para que ocorra a mutação é preciso que haja algum dano na seqüência de nucleotídeos do DNA. As células possuem um mecanismo de correção quando ocorre alguma 
falha, mas quando este mecanismo não funciona corretamente ou o dano é irreparável esta alteração na seqüência da codificação pode ser transmitida para as células filhas. Conseqüentemente, as células filhas que sobreviverem irão apresentar características novas, diferentes da célula mãe. Para a evolução das espécies a mutação é um fator importante, pois garante que características novas sejam introduzidas aos indivíduos de uma determinada população mantendo assim uma variabilidade.

\subsection{REPRODUÇÃO SEXUAL}

Combina os genes de cada pai, dividindo, rompendo e combinando cromossomos durante a criação de cada espermatozóide e óvulo (células sexuais masculinas e femininas, respectivamente). Quando espermatozóide e óvulo se combinam alguns genes do pai e alguns genes da mãe são misturados de forma aleatória, criando uma mistura única de alelos nos descendentes.

\subsection{CRUZAMENTO (CROSSOVER)}

O cruzamento, em inglês crossover ${ }^{2}$, é o fenômeno que ocorre durante a meiose onde os cromossomos homólogos se pareiam antes de se dividirem em gametas diferentes.

\footnotetext{
${ }^{2}$ Procurou-se citar o termo em inglês devido ao seu vasto uso nos trabalhos não só internacionais quanto nacionais também. Muitos autores preferem manter o termo em inglês, ao invés de traduzi-lo.
} 


\subsection{APTIDÃO BIOLÓGICA}

Capacidade de um organismo de sobreviver por tempo suficiente para se reproduzir.

Reflete também a capacidade de um organismo para se reproduzir bem, ou seja, deixar descendentes que também tenham essa aptidão. 


\section{ALGORITMOS GENÉTICOS}

Conforme introduzido em capítulos anteriores, os Algoritmos Genéticos são algoritmos de busca e otimização que se baseiam no processo da seleção natural para encontrar o ponto ótimo de uma função. Combinam a sobrevivência do mais apto e o cruzamento aleatório da informação.

Basicamente, um AG funciona da seguinte forma: cada indivíduo representa uma possível solução de um problema. Esta representação é feita através de uma codificação que pode ser com números binários, reais, etc. Um grupo de indivíduos forma uma população. A cada indivíduo é atribuído um valor de aptidão que corresponde ao seu grau de proximidade com a solução ótima. Indivíduos que possuem um maior valor de aptidão, ou seja, estão mais próximos da solução ótima (mais adaptados) possuem mais chances de se reproduzir, quando comparados a indivíduos com valor de aptidão menores.

Para selecionar os indivíduos que irão se reproduzir o algoritmo utiliza-se de métodos que privilegiam os indivíduos mais bem adaptados. Após a seleção, é feita então uma recombinação genética (cruzamento), em que indivíduos pais irão se combinar para dar origem a uma nova geração, teoricamente melhor adaptada que a anterior. $\mathrm{O}$ algoritmo segue em um loop que só irá acabar quando algum critério de parada for atingido. Na figura a seguir é apresentado um esquema básico do algoritmo. 
ESQUEMA BÁSICO DE UM ALGORITMO GENÉTICO:

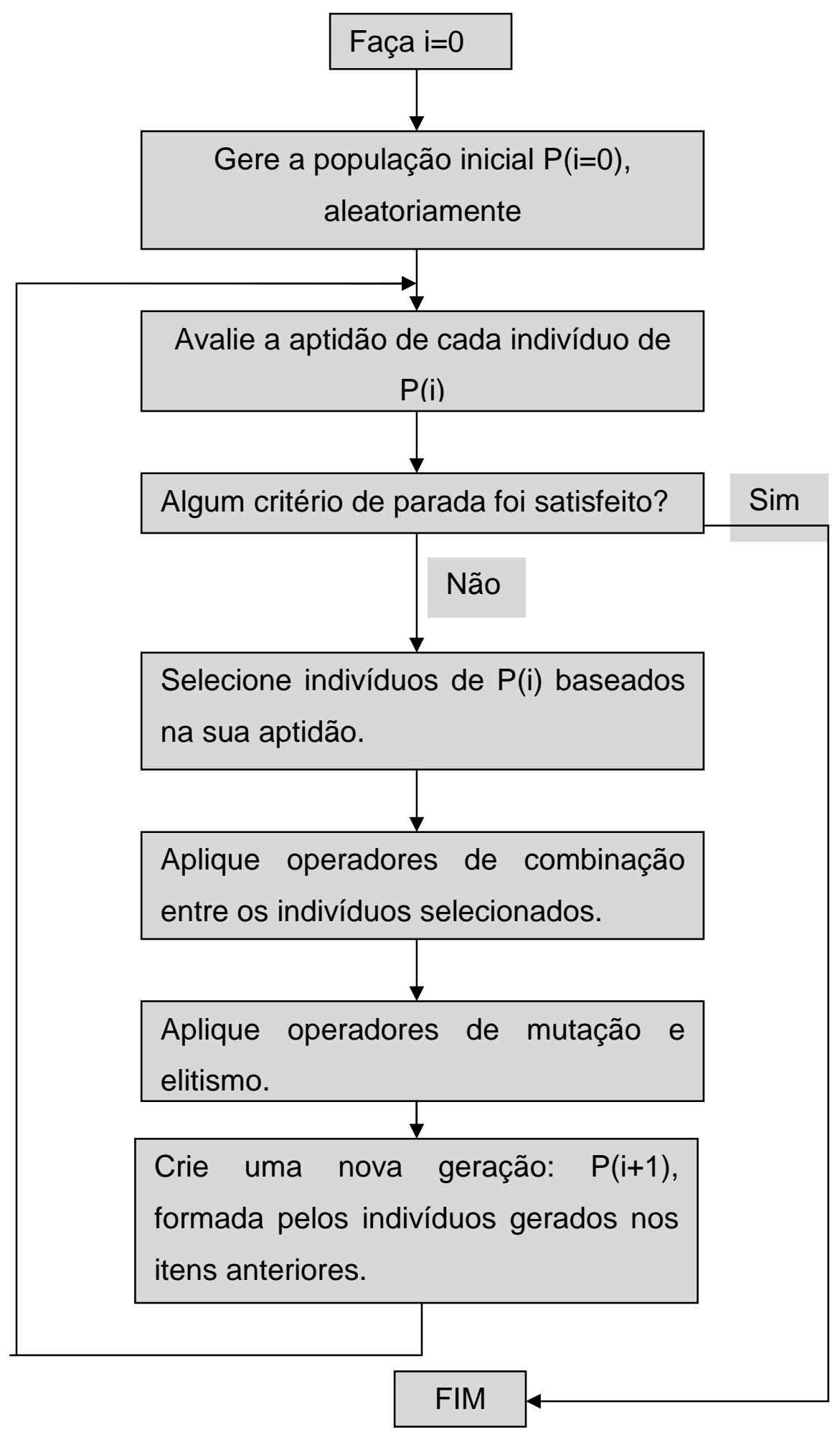

Figura 3 - Esquema Básico de um Algoritmo Genético 
Segundo (DAVIS 1991), os AG's empregam um processo adaptativo e paralelo em busca da solução ótima de problemas complexos. São considerados adaptativos, pois uma informação atual influenciará na busca futura e são considerados paralelos, pois diversos casos são analisados paralelamente, ou seja, ao mesmo tempo.

A vantagem destes algoritmos sobre outros métodos de otimização é a facilidade de se trabalhar com variáveis discretas, um fator muito útil para os problemas de otimização estrutural, pois como se sabe, na prática, na construção civil a maioria dos elementos possuem características previamente definidas (tabeladas): dimensões de vigas, diâmetro das bitolas etc. Para que a otimização estrutural dos elementos seja coerente ela deve obedecer a estes critérios de ordem prática.

Conforme apresentado anteriormente, os AG's trabalham com um conjunto de soluções. Para o seu funcionamento são utilizadas regras probabilísticas para encontrar um resultado, ao contrário de outros métodos de otimização que se baseiam em regras determinísticas. Isso é bastante útil, pois evita preocupar-se com problemas como descontinuidade das funções, existência ou não de derivada, etc. Em seu trabalho (Zuben 2004) expõe que os AG's, apesar de não-determinísticos, não são um método meramente aleatório, como se observa na transcrição abaixo:

\footnotetext{
"Algoritmos Genéticos constituem, assim, uma classe de métodos de busca de propósito geral que apresentam um balanço notável entre aproveitamento de melhores soluções e exploração do espaço de busca. Embora apresentem etapas não-determinísticas em seu desenvolvimento, os algoritmos genéticos não são métodos de busca puramente aleatórios, pois combinam variações aleatórias com seleção, polarizada pelos valores de adequação (fitness) atribuídos a cada individuo. (...) O processo de busca é, portanto, multi-direcional, através da manutenção de soluções candidatas, e encorajando a troca de informação entre as direções." (Zuben, 2004, pág.11)
}

Quanto ao tratamento de restrições, os AG's são essencialmente algoritmos de otimização não restringida. Para adaptá-los e fazer com que as restrições sejam 
obedecidas utiliza-se artifícios tais como penalizações na aptidão dos indivíduos que não atendam as restrições necessárias (este assunto será tratado com maiores detalhes no item 5.4 , sobre penalizações).

Abaixo podemos observar a correspondência (analogia) entre a genética natural e um algoritmo genético:

\section{GENÉTICA NATURAL}

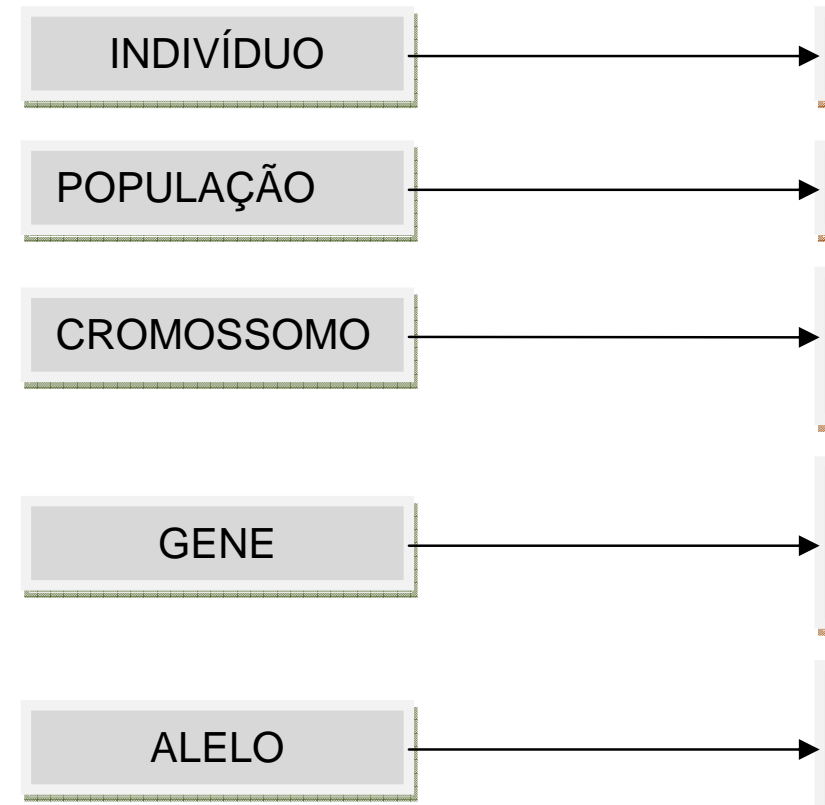

ALGORITMO GENÉTICO

SOLUÇÃO*

CONJUNTO DE SOLUÇÕES*

CODIFICAÇÃO QUE REPRESENTA O INDIVÍDUO

CODIFICAÇÃO QUE REPRESENTA A VARIÁVEL

VALOR QUE UMA VARIÁVEL PODE ASSUMIR

Figura 4 - Analogia Genética Natural - Algoritmo Genético

*Solução, neste caso, não implica dizer que a solução seja viável.

Nos próximos tópicos os conceitos essenciais sobre algoritmos genéticos e seus principais operadores serão apresentados com mais detalhes, são eles:

- Representação;

- Cromossomos e Genes;

- Função de Aptidão;

- Penalização 
- Seleção;

- Cruzamento;

- Mutação e

- Elitismo.

\subsection{REPRESENTAÇÃO}

Para que o indivíduo seja manipulado nas diversas operações do algoritmo ele precisa estar codificado. Ou seja, é necessário que se transforme todas as informações relevantes e que serão tomadas como variáveis do problema em uma codificação. Esta codificação pode ser feita de diversas maneiras. As mais usuais são:

- Representação binária e

- Representação real.

\subsubsection{REPRESENTAÇÃO BINÁRIA}

A representação binária consiste em agregar algum valor na notação binária que venha a representar a característica de alguma variável. Por exemplo, sejam altura e largura de uma viga as variáveis de um problema. Os limites impostos para a largura são de 20 a $70 \mathrm{~cm}$, tomados de cinco em cinco centímetros. Enquanto que a altura varia de 20 a $100 \mathrm{~cm}$, também tomados de cinco em cinco centímetros. Logo, podese fazer uma representação binária da seguinte forma:

a) Representação da variável largura:

Com os limites de dimensões impostos anteriormente, pode-se ter até onze tipos de largura da base, conforme é calculado a seguir: 


$$
\begin{gathered}
n=\frac{\operatorname{Lim}_{\text {sup }}-\operatorname{Lim}_{\text {inf }}}{\text { intervalo }}+1 \\
\text { Equação } 1 \\
n=\frac{70-20}{5}+1=11
\end{gathered}
$$

Logo, para a representação binária da variável largura, é necessário um número em notação binária que representa pelo menos até o valor inteiro 11 , ou seja, quatro bits:

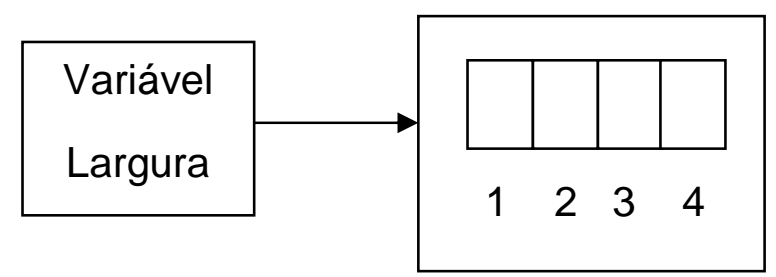

Figura 5 - Representação da variável Largura

Como se sabe, um número em binário com quatro bits pode representar até o inteiro nº15, portanto haverá uma faixa de números que ocasionalmente poderão existir e que não serão válidos, neste caso, por exemplo, são os números: 0,12,13,14 e 15. 0 programador deverá prever estes casos em sua implementação fazendo uma validação dos mesmos. A forma como se deve fazer esta validação varia de caso a caso e é inerente ao programador.

b) Representação da variável altura:

Fazendo analogamente ao item anterior, tem-se:

$$
n=\frac{\operatorname{Lim}_{\text {sup }}-\operatorname{Lim}_{\text {inf }}}{\text { intervalo }}+1=\frac{100-20}{5}+1=17
$$

Para representar em binário até o número 17 devem-se ter cinco bits, logo: 


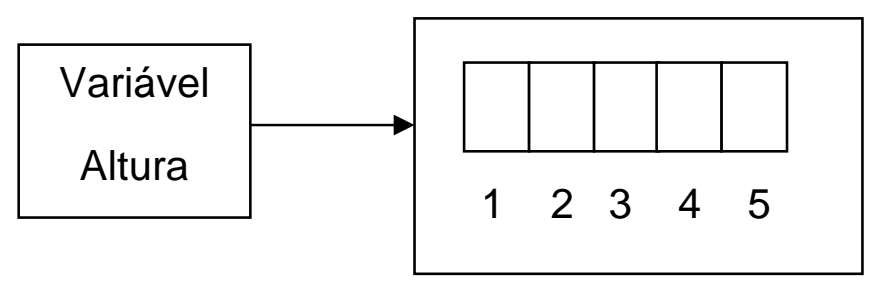

Figura 6 - Representação da variável Altura

Lembrando que o número zero e os números maiores que 17 deverão ser desvalidados pelo implementador.

È importante ressaltar que esta forma de representação demonstrada anteriormente é apenas uma das diversas formas em que se pode codificar uma variável em representação binária. Isso fica a critério do implementador.

Um ponto fraco na codificação binária é o chamado Hamming Cliffs. Pode-se definir distância de Hamming como o número de bits diferentes entre dois inteiros representados em binário, por exemplo: os números 00010 e 11010 possuem distância de Hamming igual a dois, pois dois bits os diferem um do outro. $O$ Hamming Cliffs (inicialmente definido por Goldberg) ocorre quando dois números inteiros adjacentes possuem uma distância de Hamming alta, por exemplo, os números 7 e 8 que possuem distancia igual a 4 :

$$
\begin{aligned}
& 7 \text { (Inteiro) - } 0111 \text { (Binário) } \\
& 8 \text { (Inteiro) - } 1000 \text { (Binário) }
\end{aligned}
$$

Logo, pode-se observar que uma pequena mudança em um desses bits causaria um grande deslocamento da variável no universo de busca, o que nem sempre é desejado. 


\subsubsection{REPRESENTAÇÃO REAL}

A representação em real não tem sido muito adotada pelos implementadores de AG's. Acredita-se que um dos motivos se deva ao fato da representação binária ser simples em sua manipulação. Porém quando se precisa de uma maior precisão numérica o código pode ficar tão grande, que acaba tornando este tipo de codificação ineficiente. Para estes casos, costuma-se adotar a representação real, que traz uma maior precisão à codificação.

Segundo (Herrera, F Lozano, Verdegay 1998) é interessante utilizar representação real quando se necessita cobrir um domínio bem abrangente, já que com representação binária isso implicaria num custo computacional alto. Em seu trabalho (Brun 2005) cita que a vantagem em se utilizar representação real ao invés da binária é a capacidade de se poder explorar gradualmente as funções com variáveis contínuas. Essa evolução gradual se aplica ao fato de ligeiras mudanças nas variáveis corresponderem a pequenas mudanças na função. É interessante explorar gradualmente o domínio do problema, pois a solução obtida pode ser melhor através de uma pequena mudança nos parâmetros.

È importante ressaltar que dentro da representação real os operadores de mutação e cruzamento são realizados de forma diferente do método utilizado na técnica tradicional.

\subsection{CROMOSSOMOS E GENES}

Fazendo uma analogia com a genética, um gene pode ser considerado uma característica inerente ao problema, ou seja, uma variável. Um conjunto de variáveis (genes) constitui um cromossomo, que vem a representar um indivíduo. Na verdade um indivíduo pode vir a ser caracterizado também por mais de um cromossomo. 


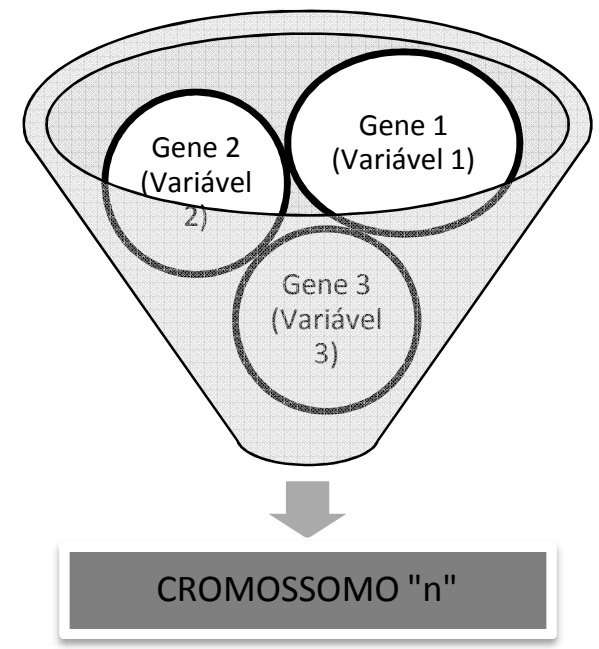

Figura 7 - Representação de um cromossomo

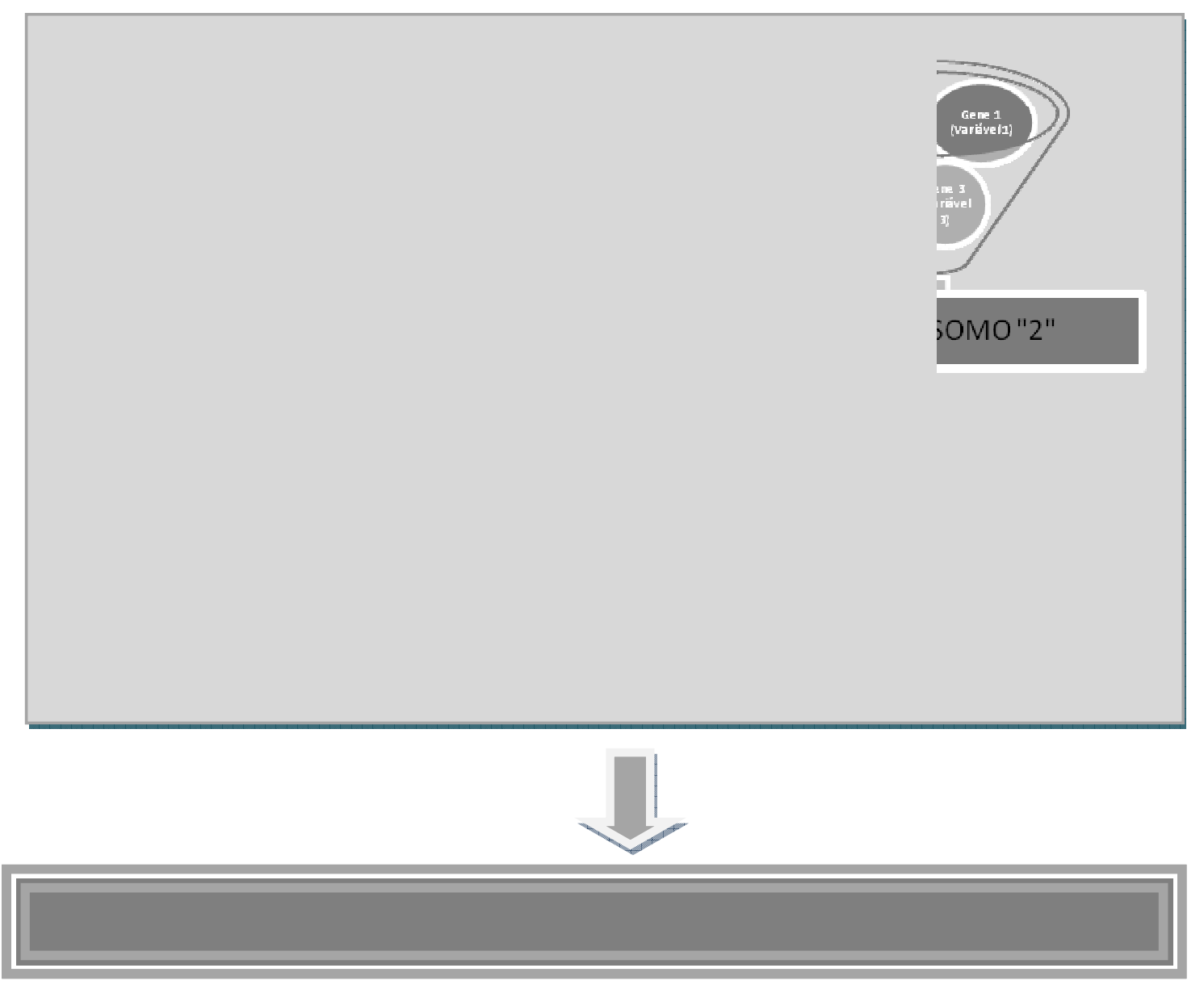

Figura 8 - Representação de um Indivíduo 


\subsection{FUNÇÃO DE APTIDÃO}

A função de aptidão mede a adaptação do indivíduo, ou seja, o quão boa é a solução para um dado problema. Aptidão, em inglês fitness, possui o mesmo significado que o termo adotado na biologia, ou seja, afere a capacidade do indivíduo sobreviver para a próxima geração.

Novamente fazendo-se uma analogia com a genética, pode-se dizer que a função de aptidão representa o genótipo do indivíduo. Para se descobrir qual o fenótipo associado é necessário que este genótipo seja decodificado. Para cada aplicação de um problema existe uma função de aptidão que o caracteriza.

De uma maneira geral a função de aptidão funciona conforme ilustrado abaixo:

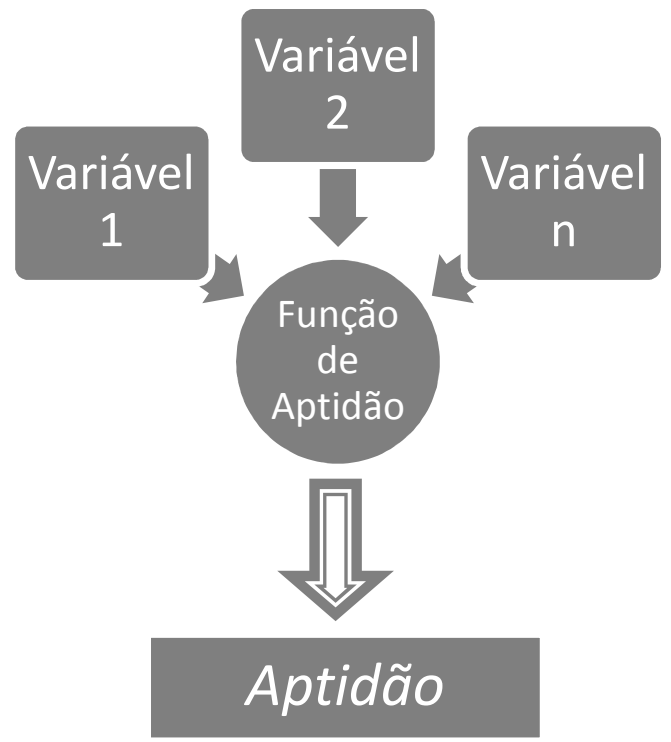

Figura 9 - Representação da Função de Aptidão 


\subsection{PENALIZAÇÃO}

Os AG's são essencialmente um método de otimização sem restrições. Para fazer com que as restrições sejam obedecidas é utilizado o método da penalização. Este método, como o próprio nome diz, consiste em penalizar a função de aptidão acrescentando ou removendo a ela um determinado valor para cada restrição não obedecida. Esta penalização é obtida definindo-se uma função auxiliar que é então incorporada à função de aptidão original, transformando, assim, um problema de otimização com restrições em um problema de otimização sem restrições.

Apesar de existirem diversas formas de se aplicar a função de penalização e que, cada pessoa pode definir a sua, existem basicamente duas formas (para o caso de problemas de minimização). Esta forma vai depender do tipo da restrição a ser obedecida. Por exemplo, seja o problema de minimização da função sujeita a restrições de igualdade, apresentado abaixo:

$$
\left\{\begin{array}{c}
\text { Minimizar } f(x) \\
\text { Sujeito a } h(x)=0
\end{array}\right.
$$

Aplicando-se uma função de penalização, se transformaria em:

$$
\operatorname{Minimizar} f^{*}(\mathrm{x})=\mathrm{f}(\mathrm{x})+\eta^{*}\left[\mathrm{~h}_{\mathrm{j}}(\mathrm{x})\right]^{2}
$$

Equação 2 - Função com penalização para restrições de igualdade

Onde $\eta$ é um número real positivo razoavelmente grande em relação às grandezas do problema e j corresponde a uma restrição de igualdade do problema. 
Agora, seja o problema de minimização com restrições de desigualdade, conforme apresentado abaixo:

$$
\left\{\begin{array}{l}
\text { Minimizar } \mathrm{f}(\mathrm{x}) \\
\text { Sujeito a } \mathrm{g}(\mathrm{x}) \leq 0
\end{array}\right.
$$

O problema então poderia ser transformado em:

$$
\operatorname{Minimizar} f^{*}(x)=f(x)+\eta * \operatorname{máximo}\left[0, g_{i}(x)\right]
$$

\section{Equação 3 - Função com penalização para restrições de desigualdade}

Para problemas com diversas restrições tanto de igualdade quanto de desigualdades, pode-se adotar a seguinte penalização, bastante completa:

$$
\operatorname{Minimizar} f^{*}(x)=f(x)+\eta^{*} \sum_{i=1}^{k}\left[\operatorname{máximo}\left[0, g_{i}(x)\right]\right]+\eta^{*} \sum_{j=1}^{m}\left(h_{j}(x)\right)^{2}
$$

\section{Equação 4 - Função com penalização completa}

Onde:

$\mathrm{k}$ = número de restrições de desigualdade;

$\mathrm{m}$ = número de restrições de igualdade. 


\subsection{SELEÇÃo}

A seleção é um dos principais operadores de um AG. É através deste operador que são escolhidos os indivíduos que irão se reproduzir e, conseqüentemente, transmitir os seus genes para a próxima geração. Os autores costumam distinguir três mecanismos de seleção.

- Seleção por amostragem direta: Os indivíduos são selecionados para a reprodução segundo algum critério específico. É o caso quando, por exemplo, o programador do problema utiliza como critério de seleção sempre os " $n$ " melhores indivíduos da população.

- Seleção por amostragem aleatória: neste método de seleção todos os indivíduos possuem a mesma chance de serem selecionados para a reprodução.

- Seleção por amostragem estocástica: este tem sido o método mais utilizado para seleção. Nele cada indivíduo possui uma probabilidade de seleção proporcional ao seu grau de aptidão. O programa implementado neste trabalho utiliza este tipo de método de seleção.

Dentre os diversos métodos de seleção estocásticos, existem três que são mais utilizados e serão explicados com mais detalhes nos itens que seguem. São eles a seleção por roleta, a seleção baseada em classificação e o torneio.

\subsubsection{SELEÇÃO POR ROLETA}

O método da roleta consiste em dar para cada indivíduo chances de seleção proporcionais a sua aptidão. Assim, indivíduos mais bem adaptados, terão maior probabilidade de serem escolhidos. Existem diversas variações do método da roleta, porém em síntese eles funcionam da seguinte maneira: Sejam $f_{1}, f_{2}, \ldots, f_{n}$ os valores 
da aptidão de cada indivíduo de uma população de tamanho n. A probabilidade de seleção de cada indivíduo é então determinada pela equação abaixo:

$$
P_{i}=\frac{f i}{\sum_{k=1}^{n} f_{k}}
$$

Equação 5 - Probabilidade de Seleção - Método da Roleta

Onde i é a posição do indivíduo. Apesar de bastante usado e relativamente eficiente, este método possui algumas falhas. Por exemplo, se na população inicial houver um ou alguns poucos indivíduos com valor de aptidão bom, porém não os melhores, e o resto da população não for muito boa, então esses poucos indivíduos irão rapidamente dominar a população, tornando-a homogênea e impedindo-a de explorar todas as suas potencialidades, ou seja, o algoritmo poderá convergir para um mínimo local.

Outro problema que pode ocorrer é o caso da população inicial ser muito homogênea, ou seja, formada por indivíduos parecidos. Sendo assim, será difícil fazer a população evoluir, pois a tendência será ela se tornar cada vez mais homogênea. Uma opção para resolver este problema seria a mutação, que será explicada em tópico posterior.

\subsubsection{SELEÇÃO BASEADA EM CLASSIFICAÇÃO}

O método de seleção por classificação é bastante simples: primeiro todos os indivíduos são classificados de acordo com o seu valor de aptidão. Em seguida a probabilidade de seleção é definida segundo esta classificação. Como se pode notar ele não determina a probabilidade de seleção diretamente pela aptidão, mas faz isso indiretamente.

Existem diversas ramificações deste método. Baker 1985 apresenta o seguinte: após classificar todos os indivíduos por ordem de sua aptidão ele induz que o melhor 
indivíduo terá a melhor probabilidade, e o pior indivíduo terá a pior probabilidade de seleção. Os demais indivíduos intermediários possuem sua probabilidade de seleção variando linearmente com o seu grau de aptidão, conforme indicado na fórmula abaixo:

$$
P i=\frac{1}{\mu} *\left(\eta_{\max }-\left(\eta_{\max }-\eta_{\min )}\right) *\left(\frac{i-1}{\mu-1}\right)\right)
$$

Equação 6 - Probabilidade de seleção por classificação, segundo Baker-1985

Onde:

$P_{i}=$ Probabilidade de seleção do iésimo indivíduo;

i = Posição do indivíduo;

$\mu=$ Tamanho da população;

$\eta_{\max }=$ Probabilidade de seleção do melhor indivíduo;

$\eta_{\min }=$ Probabilidade de seleção do pior indivíduo;

Existem outros métodos propostos por diversos autores para determinar a probabilidade de seleção. Alguns utilizam uma função exponencial, ao invés da função linear, por exemplo. Mas em suma, todos têm o mesmo principio: selecionar os indivíduos proporcionalmente a sua classificação no "ranking" da população.

\subsubsection{SELEÇÃO POR TORNEIO}

A seleção por torneio se diferencia dos outros métodos de seleção apresentados anteriormente por não precisar se basear numa informação global da população. Ela funciona da seguinte forma: a população é dividida em diversos subgrupos, de dois ou mais indivíduos. Os melhores indivíduos de cada subgrupo são então selecionados para a reprodução. 


\subsection{CRUZAMENTO}

O cruzamento, em inglês crossover, é um dos principais operadores de um algoritmo genético. È nele onde as informações são trocadas entre os indivíduos a fim de gerar uma nova prole. Existem diversas formas de se fazer um cruzamento, os autores costumam classificar em:

- Cruzamento uniponto - o cruzamento é realizado a partir de um ponto prédeterminado. A partir deste ponto as informações são então trocadas.

- Cruzamento multiponto: Possui o mesmo fundamento do cruzamento uniponto, porém aplicado a várias posições do cromossomo.

- Cruzamento uniforme: Determina, através de um parâmetro global, qual a probabilidade de cada ponto do cromossomo ser trocado.

O tipo de cruzamento mais simples e comumente utilizado é o que apresenta um único ponto de troca. Funciona conforme apresentado a seguir:

\section{GENITORES}

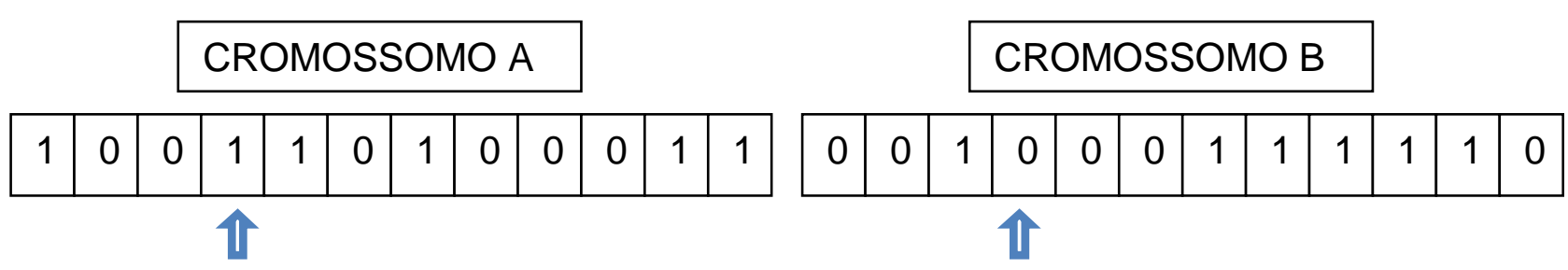

Figura 10 - Cruzamento uniponto - Genitores

Sejam dois cromossomos, A e B, conforme indicado na Figura 10. Para a realização de um cruzamento uniponto fixa-se então um ponto onde, a partir dele, os cromossomos em contato irão se dividir e trocar entre si a informação (este ponto pode ser fixo ou não ao longo do programa). A seta indica o ponto de cruzamento do exemplo. Ao final deste cruzamento eles terão gerado então novos descendentes. Conforme se observa na Figura 11. 


\section{DESCENDENTES}

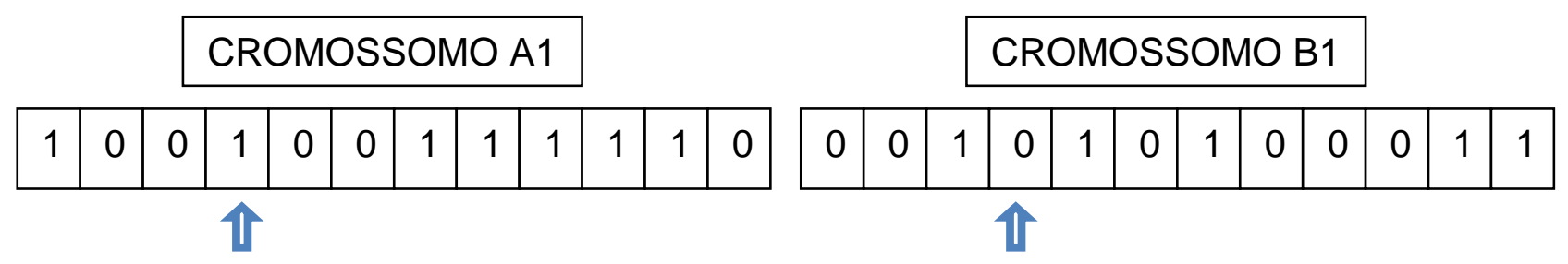

Figura 11 - Cruzamento uniponto - Descendentes

\subsection{MUTAÇÃO}

A mutação tem como principal objetivo garantir uma maior variabilidade na população. Uma das dificuldades dos métodos evolutivos está no fato da população tender a se tornar cada vez mais homogênea. Isto pode fazer com que o resultado encontrado seja um mínimo local.

O operador da mutação pode vir a introduzir na população indivíduos com características novas, que antes não existiam. Se essa característica for boa para melhorar a aptidão do indivíduo ela então tenderá a se "multiplicar" entre os demais nas próximas gerações. Caso seja uma característica que prejudique a aptidão do indivíduo, ela tenderá a sumir com o tempo.

A mutação geralmente é aplicada após o cruzamento. Ela é utilizada seguindo uma determinada probabilidade de mutação $\left(P_{m}\right)$. Normalmente utiliza-se uma taxa de probabilidade de mutação baixa (em torno de $0,1 \%$ a $5 \%$ ), caso contrário o cruzamento não faria sentido e tornaria a busca meramente aleatória. Alguns pesquisadores aconselham que a escolha da taxa de mutação se relacione com 0 tamanho dos cromossomos e das populações através de fórmulas empíricas. Abaixo segue a opinião de alguns autores a respeito da taxa de probabilidade de mutação $\left(P_{m}\right)$. 
- DE JONG (1975) $-\mathrm{P}_{\mathrm{m}}$ deve ser inversamente proporcional ao tamanho da população.

- SHAFFER (1994) - Sugere a seguinte equação, onde $N_{\text {pop }}$ é o tamanho da população e K é o tamanho do cromossomo:

$$
P_{m}=\frac{1}{\left(N_{\text {pop }} \cdot K^{\frac{1}{2}}\right)}
$$

Equação 7 - Probabilidade de Mutação, segundo Shaffer 1994

Resumidamente, a mutação funciona da seguinte forma: após o cruzamento, a cada bit dos cromossomos descendentes é verificada a probabilidade de mutação. Isto é feito gerando-se aleatoriamente um número entre zero e um. Se este número for menor ou igual à probabilidade de mutação $\left(\mathrm{P}_{\mathrm{m}}\right)$ o bit deverá ser trocado. Caso contrário nada ocorre. Esta troca, para cromossomos codificados em binário, significa substituir o zero por um e vice-versa.

A mutação em cromossomos que utilizam codificação real é diferente da binária. Existem diversas técnicas para este tipo de mutação. (Del Savio, et al. 2005) cita dois tipos:

- Mutação real: seleciona aleatoriamente o elemento $\mathrm{K}_{\mathrm{im}}$ do cromossomo $\mathrm{C}_{\mathrm{i}}$. Gera um número entre zero e um aleatoriamente. Se este número for menor ou igual ao valor da probabilidade de mutação $\left(P_{m}\right)$, ele então será substituído por $\mathrm{K}_{\mathrm{im}}{ }^{*}$, sendo:

$$
K_{\text {im }}^{*} \in\left[L_{\text {inf }}, L_{\text {sup }}\right]
$$

\section{Equação 8 - Mutação Real}

$L_{\text {inf }}$ e $L_{\text {sup }}$ são limites inferiores e superiores do valor de $K_{i m}$, previamente definidos pelo implementador.

- Mutação de ajuste próprio: procura por uma solução fechada baseada em mudanças aleatórias nas duas direções (+ e -). 


\subsection{ELITISMO}

O elitismo tem por objetivo selecionar o melhor ou os melhores indivíduos de uma geração e automaticamente introduzi-los na geração seguinte, sem que eles passem pelo cruzamento. Com isso o algoritmo pode evitar que um resultado que seja muito bom seja perdido ou piorado.

O elitismo foi proposto por DeJong (1975), em um dos trabalhos pioneiros sobre AG's. Existem diversas formas de elitismo. Abaixo são citados alguns autores da bibliografia e a forma como aplicaram e/ou sugerem o elitismo nos seus trabalhos:

- (Croce, Ferreira e Lemonge 2004) - São feitas nove cópias do melhor elemento para a próxima geração.

- (Del Savio, et al. 2005) - Cria "n" indivíduos para substituir os "n" piores indivíduos da população. Através de um parâmetro denominado GAP, controla a porcentagem da população que será substituída. Geralmente, nos AG's tradicionais o valor do GAP $=1$, ou seja, $100 \%$ dos indivíduos são substituídos.

- (Gantovnik 2005) - Copia o melhor indivíduo para a próxima geração. O autor sugere também copiar não apenas o melhor, mas também o segundo melhor, o terceiro melhor e assim sucessivamente.

- (Gillman 2005) - A nova geração é combinada com a geração anterior. Os indivíduos são então classificados por ordem do seu valor de aptidão. Os n melhores (sendo $\mathrm{n}$ o tamanho da população em cada geração) irão para a geração seguinte. Desta forma, os descendentes têm que competir com seus genitores para sobreviver para a próxima geração.

- (Kim e Weck 2004) - O melhor indivíduo substitui os 30\% piores indivíduos em cada geração.

- (Silva 2001) - Propõe guardar $10 \%$ dos melhores indivíduos para a próxima geração. 
- Wu and Chow - Utiliza a equação a seguir para determinar o GAP:

$$
G A P=\frac{2}{N_{p}}
$$

\section{Equação 9 - GAP, segundo Wu e Chow}

Onde Np é o tamanho da população. Isso significa que apenas dois indivíduos são selecionados para a reprodução. Eles irão substituir os dois piores indivíduos da população atual. Segundo o autor, esta estratégia leva a uma significante redução do número de avaliações da função objetivo e funciona mesmo em grandes populações. 


\section{APRESENTAÇÃO DO PROBLEMA}

\subsection{PREAMBULO}

A fim de aplicar os conceitos de algoritmos genéticos foi desenvolvido um programa que visa otimizar topológica e parametricamente vigas de concreto armado submetidas a um carregamento distribuído.

Nos próximos tópicos serão apresentadas as principais características do problema a ser resolvido e no capitulo seguinte será apresentada a aplicação dos AG's a este problema.

Faz-se necessário informar que a proposta inicial para este trabalho era realizar otimização topológica e paramétrica de pavimentos tipo de edifício, incluindo a iteração de todas as vigas de um pavimento, com suas respectivas lajes e pilares. Para que o proposto trabalho fosse resolvido muitas características foram incluídas ao problema que de certa forma, se analisados isoladamente não possuem significado algum, sendo assim desnecessários, porém, se levado o problema inicialmente pensado, estas características são relevantes. Apesar deste objetivo inicial não ter sido alcançado, optou-se em não excluí-las da formulação e aplicação da teoria. Portanto, em alguns trechos, se observará que alguns itens são dispensáveis. Buscou-se ser o mais didático possível a fim de que, caso algum pesquisador queira continuar este trabalho isto será útil. Fazendo-se uma analogia com a biologia, funciona como os órgãos residuais que os animais possuem. Em um momento do desenvolvimento do animal estes órgãos eram necessários, porém com a sua evolução apesar deles não serem mais utilizados, seus vestígios continuaram. No caso deste projeto, trata-se de um conceito similar, porém oposto. Caso se queira que o projeto "evolua" as ferramentas necessárias já foram preparadas. 


\subsection{FORMULAÇÃO}

Seja uma viga de concreto armado, de seção transversal retangular, comprimento L, com as possíveis posições de apoios intermediários ${ }^{3}$ indicados nos nós 1 ao 5 e submetida a um carregamento distribuído $Q$, conforme indicado abaixo:

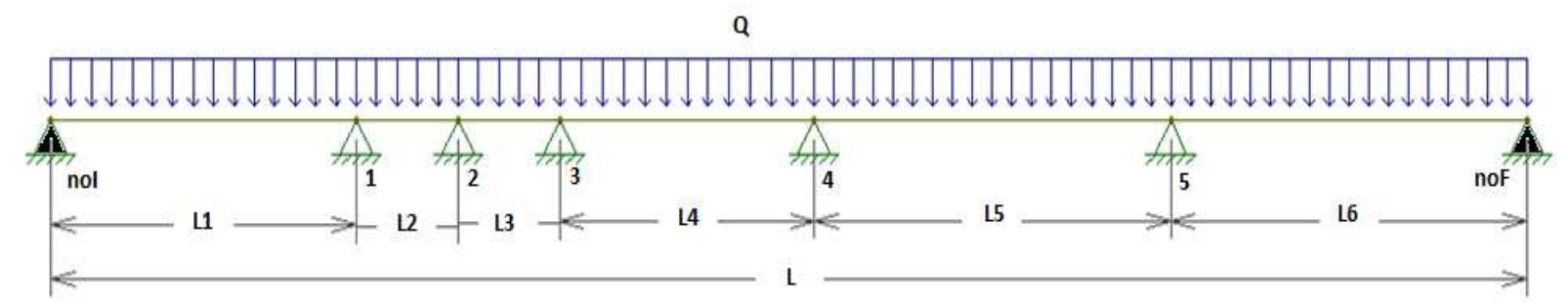

Figura 12 - Configuração da viga modelo

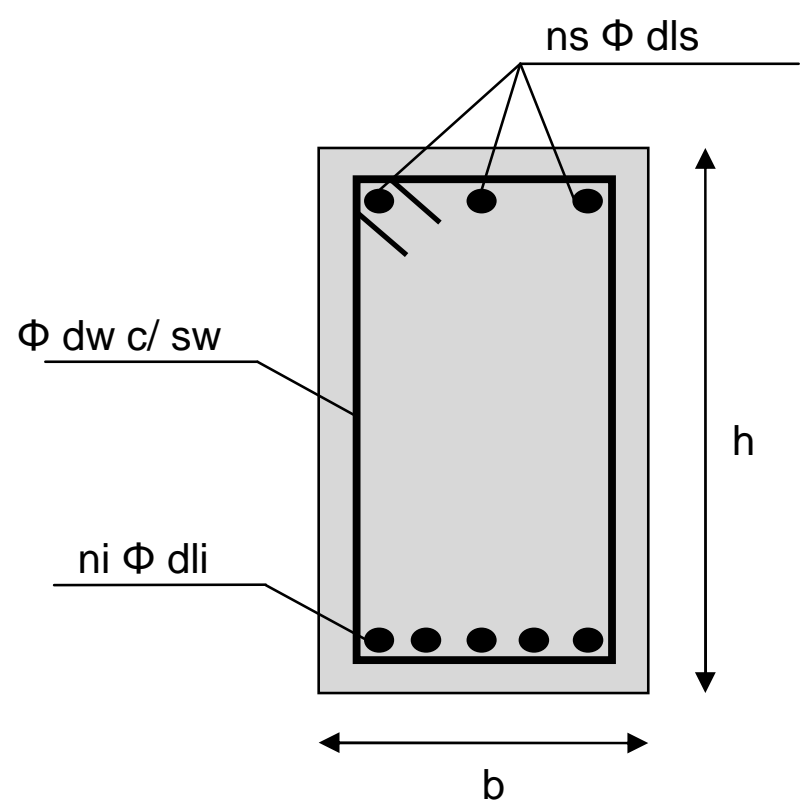

Figura 13 - Seção transversal da viga modelo

${ }^{3}$ Estas possíveis posições vêm de aspectos pré-determinados de projeto, como por exemplo, posições de pilares, definidos pela arquitetura. 
O objetivo é minimizar o custo da viga, ou seja:

$$
\min \left(C_{v}\right)=C_{v, m} * L
$$

\section{Equação 10 - Função Objetivo}

Onde:

$C_{v}=$ Custo total da viga $(\mathrm{R} \$)$;

$C_{v, m}=$ Custo da viga, por metro linear $(\mathrm{R} \$ / \mathrm{m})$;

$L=$ Comprimento total da viga $(\mathrm{m})$.

Os determinantes para o custo da viga a serem considerados são: o concreto, o aço e a forma ${ }^{4}$. Por conseguinte o custo de uma viga por metro, levando-se em conta estes três fatores é determinado pela seguinte equação:

$$
C_{v, m}=C_{C} * b * h+C_{a} *\left[n i * \gamma_{l i, m}+n s * \gamma_{l s, m}+\frac{100}{s w} * l_{w} * \gamma_{w, m}\right]+C_{F} *(b+2 * h)
$$

\section{Equação 11 - Custo de uma viga de concreto por metro linear $(R \$ / m)$}

Onde:

$C_{c}=$ Custo do concreto por $\mathrm{m}^{3}\left(\mathrm{R} \$ / \mathrm{m}^{3}\right)$.

$b=$ Base da viga $(\mathrm{m})$;

$h=$ Altura da viga $(\mathrm{m})$;

$C_{a}=$ Custo do aço CA50 por $\mathrm{Kg}(\mathrm{R} \$ / \mathrm{Kg})$.

$n i=$ Quantidade de barras longitudinais inferiores;

$\gamma_{l i, m}=$ Peso por metro da barra longitudinal inferior $(\mathrm{Kg} / \mathrm{m})$;

\footnotetext{
${ }^{4}$ É interessante ressaltar que existem outros fatores que entram no custo de uma viga e poderiam ser colocados como determinantes, como por exemplo, a mão-de-obra.
} 
$n s=$ Quantidade de barras longitudinais superiores;

$\gamma_{l s, m}=$ Peso por metro da barra longitudinal superior $(\mathrm{Kg} / \mathrm{m})$;

$s w=$ Espaçamento entre estribos $(\mathrm{cm})$;

$l_{w}=$ Comprimento total de um estribo $(\mathrm{m}) ;$

$\gamma_{w, m}=$ Peso por metro da barra de estribo $(\mathrm{Kg} / \mathrm{m})$;

$C_{f}=$ Custo da madeira (forma) por metro quadrado $\left(\mathrm{R} \$ / \mathrm{m}^{2}\right)$;

$d l i=$ Diâmetro da barra longitudinal inferior $(\mathrm{cm})$;

$d l s=$ Diâmetro da barra longitudinal superior $(\mathrm{cm})$;

$d w=$ Diâmetro do estribo $(\mathrm{cm})$;

O problema está sujeito às seguintes restrições:

- Restrições Laterais:

$0.20 \leq b \leq 0.90$, sendo $b \in M / M=\left\{x / x \in \mathbb{R}^{+}\right.$e $x$ é múltiplo de 0.05$\}$

$0.25 \leq h \leq 1.75$, sendo $h \in N / N=\left\{x / x \in \mathbb{R}^{+}\right.$e $x$ é múltiplo de 0.05$\}$

$d l i=\{1.0,1.25,1.6,2.0,2.5,3.2\}$, dli em $\mathrm{cm}$.

$d l s=\{6.3,8.0,1.0,1.25,1.6,2.0,2.5\}, d l s \mathrm{em} \mathrm{cm}$.

$d w=\{6.3,8.0,1.0\}, d w$ em cm.

$2 \leq n i \leq 8$, sendo $n i \in \mathbb{Z}$

$2 \leq n s \leq 8$, sendo $n s \in \mathbb{Z}$

$s w=\{5.0,7.5,10.0,12.5,15.0,20.0,25.0\}, s w$ em cm. 
- Restrições de Comportamento:

$$
\begin{aligned}
\mathrm{V}_{\mathrm{SD}} & \leq \mathrm{V}_{\mathrm{RD}} \\
M_{S D}^{+} & \leq M_{R D}^{+} \\
M_{S D}^{-} & \leq M_{R D}^{-}
\end{aligned}
$$

Onde,

$\mathrm{V}_{\mathrm{SD}}=$ Cortante solicitante de cálculo da viga.

$\mathrm{V}_{\mathrm{RD}}=$ Cortante resistente de cálculo da viga.

$M_{S D}^{+}=$Momento Positivo ${ }^{5}$ solicitante de cálculo da viga.

$M_{R D}^{+}=$Momento Positivo resistente de cálculo da viga.

$M_{S D}^{-}=$Momento Negativo solicitante de cálculo da viga .

$M_{R D}^{-}=$Momento Negativo resistente de cálculo da viga.

As restrições de 1 a 8 , restrições laterais, referem-se a critérios de execução do projeto. Serão tratadas com maiores detalhes no tópico seguinte.

As restrições 9 a 11, restrições de comportamento, referem-se a critérios de resistência do material aos esforços solicitantes.

\subsection{VARIÁVEIS DO PROBLEMA}

As variáveis do problema podem ser classificadas em variáveis topológicas e variáveis paramétricas. Conforme o tipo de otimização na qual elas estão envolvidas.

\footnotetext{
${ }^{5}$ Define-se como momento positivo aquele que traciona as fibras inferiores da seção transversal da viga, e negativo o que traciona as fibras superiores, segundo a regra da mão-direita.
} 
Variáveis Topológicas:

- $\boldsymbol{n}=(\mathrm{n} 1, \mathrm{n} 2, \mathrm{n} 3, \mathrm{n} 4, \mathrm{n} 5)$, Vetor de nós intermediários de cada viga;

Variáveis Paramétricas:

- $b=$ Base da viga;

- $h=$ Altura da viga;

- $\quad d l i=$ Diâmetro da barra longitudinal inferior;

- $\quad d l s=$ Diâmetro da barra longitudinal superior;

- $d w=$ Diâmetro dos estribos;

- $n i=$ Quantidade de barras longitudinais inferiores;

- $n s=$ Quantidade de barras longitudinais superiores;

- $s w=$ Espaçamento entre estribos.

\subsection{RESTRIÇÕES}

As restrições do problema têm por objetivo garantir que sejam obedecidos os dois critérios abaixo indicados:

- Critérios de resistência e;

- Critérios de execução.

\subsubsection{CRITÉRIOS DE RESISTÊNCIA}

Atender aos critérios de resistência significa garantir que os esforços solicitantes do elemento sejam menores ou pelo menos iguais aos esforços resistentes do mesmo,ou seja, a viga deverá ser verificada para o Estado Limite Último (ELU).

Como se sabe, uma viga submetida a carregamento distribuído estará sujeita a flexão, conforme figura abaixo: 


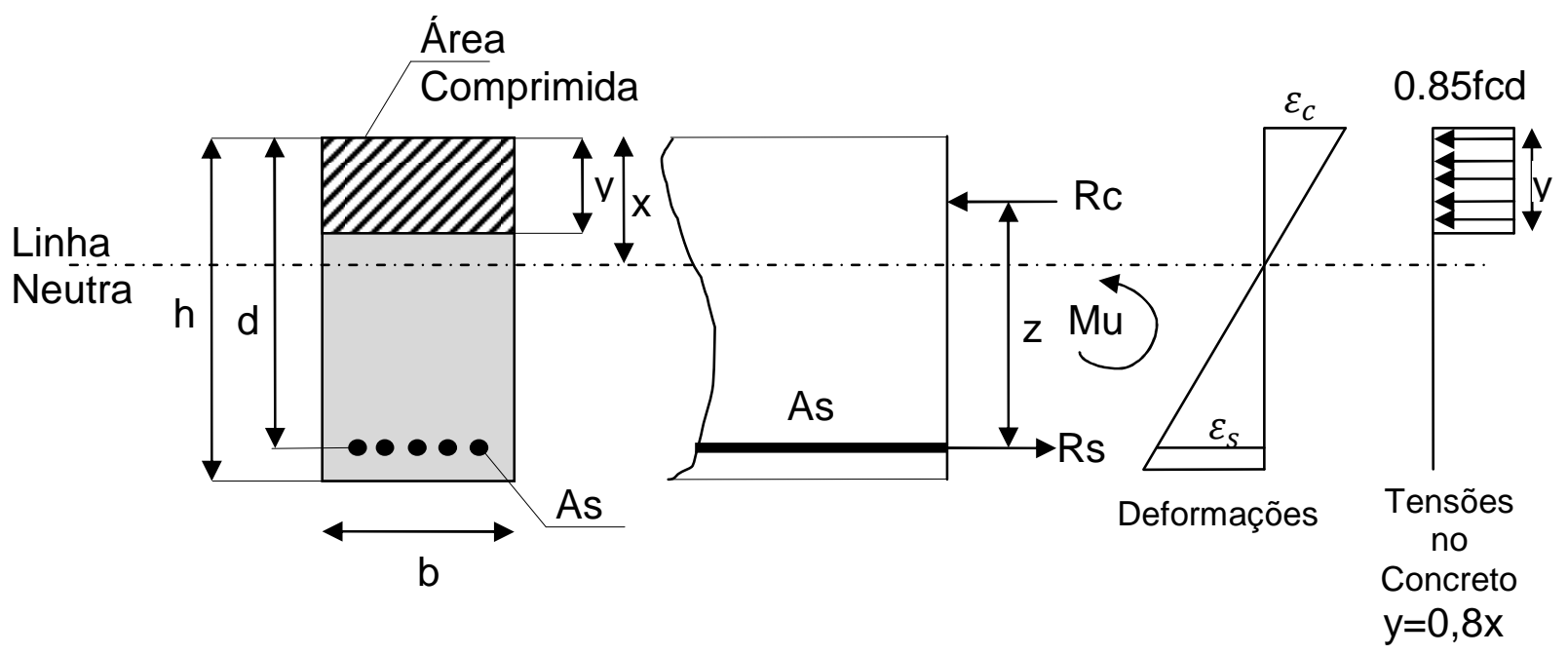

Figura 14 - Seção transversal de viga sujeita a flexão

Sendo:

Rc = Força de compressão no concreto;

Rs = Força de tração no aço;

$\varepsilon_{c}=$ Deformação no trecho mais comprimido do concreto;

$\varepsilon_{s}=$ Deformação de tração no aço.

Para que esta configuração seja válida, algumas hipóteses foram admitidas:

1. Sob a influência das solicitações normais, as seções transversais permanecem planas (hipótese de Bernouilli);

2. Despreza-se a resistência do concreto á tração;

3. A deformação máxima no concreto comprimido é de 3.5/1000;

4. Admite-se perfeita aderência entre concreto e aço, ou seja, tanto o aço quanto o concreto que o envolve sofrerão as mesmas deformações.

5. Admite-se a simplificação do diagrama parábola retângulo de tensões no concreto pelo seu diagrama simplificado retangular (com tensão máxima a 0,85 de fcd e altura y de $0,8 x$ ). 
6. A tensão na armadura é a correspondente à deformação determinada de acordo com as hipóteses anteriores e obtida do diagrama tensão-deformação do aço.

Os domínios de ELU para as seções de concreto armado são:

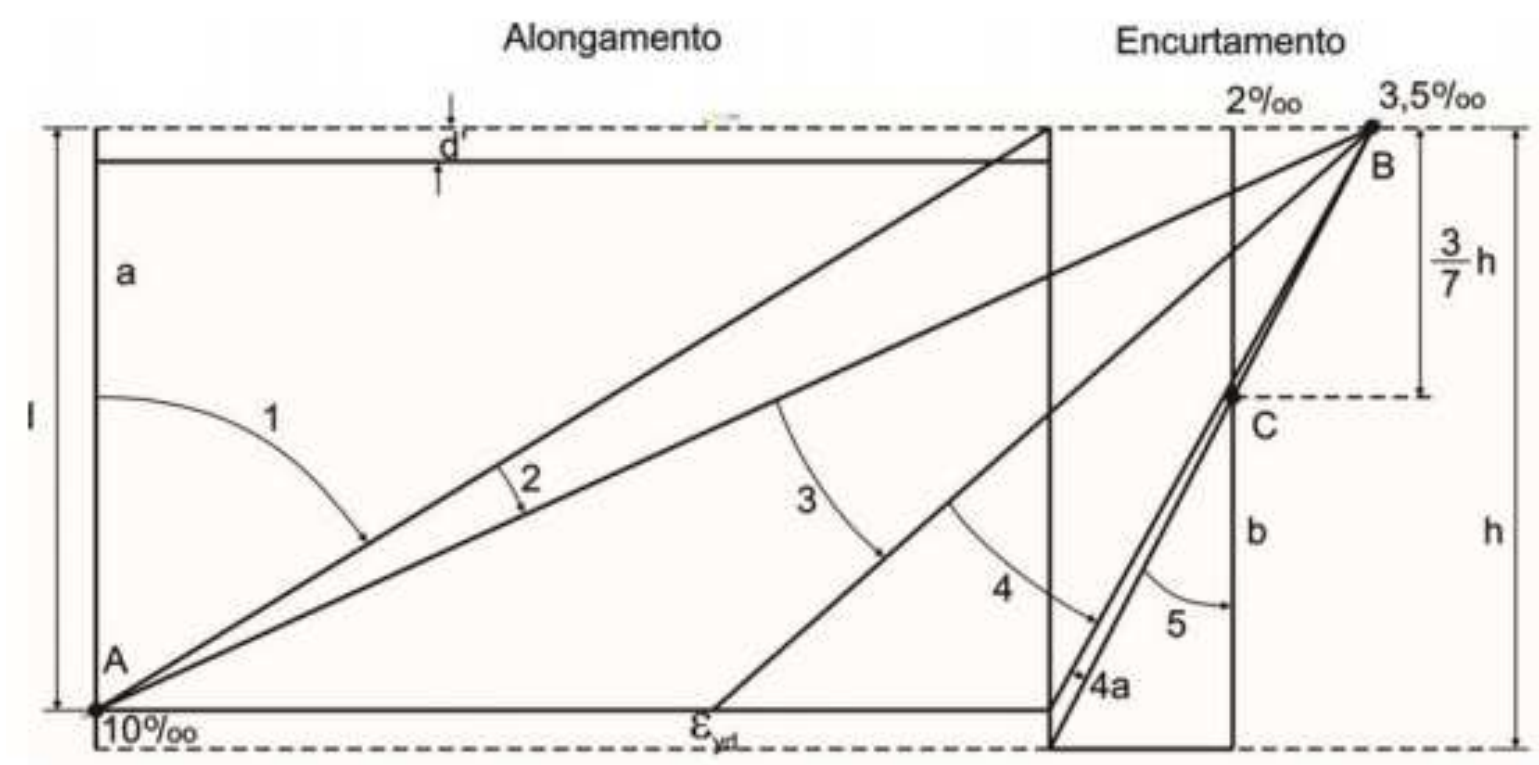

Figura 15 - Domínios de dimensionamento em ELU

O domínio 1 abrange os casos onde ocorre tração não uniforme, o ponto $\mathrm{A}$ indica $\mathrm{O}$ limite para ruptura convencional por deformação plástica excessiva do aço (10/1000). A reta "a" corresponde à tração uniforme.

O domínio 2 abrange casos onde ocorre flexão simples ou composta sem ruptura a compressão do concreto e aço com alongamento máximo permitido.

No domínio 3 o elemento encontra-se submetido a flexão simples ou composta com ruptura do concreto á compressão e com escoamento do aço.

No domínio 4 (situação antieconômica) ocorrem os casos de flexão simples ou composta com ruptura à compressão do concreto e aço tracionando sem escoamento. 
O trecho 4a abrange os casos de flexão composta, com armaduras comprimidas.

O domínio 5 é o trecho onde se tem o elemento submetido á compressão não uniforme, sem tração e a "b" corresponde à compressão uniforme.

Por equilíbrio temos:

$$
\begin{aligned}
& M_{r d}=R c * z=R s * z \\
& R c=R s
\end{aligned}
$$

Fazendo-se:

$$
\begin{aligned}
& M_{r d}=A_{s} * f_{y d} *(d-0,5 y)(3) \\
& M_{r d}=b * 0,85 * f_{c d} * y *(d-0,5 * y)(4) \\
& A_{s} * f_{y d}=0,85 * b * f_{c d} * y(5)
\end{aligned}
$$

Com (5) determina-se o valor de y e, por conseguinte, determina-se Mrd que deverá ser comparado ao Msd.

\subsubsection{CRITÉRIOS DE EXECUÇÃO}

Foram considerados critérios de execução aqueles que visam manter o projeto em concordância com as diversas práticas de obra que já estão radicadas na sociedade. São eles:

- Largura da base e altura em múltiplos de cinco cm;

- Bitola das armações conforme dimensões padronizadas no mercado;

- Espaçamento dos estribos em valores tabelados;

- Largura mínima e máxima da base;

- Largura mínima e máxima da altura;

Os valores a serem adotados são conforme foram apresentados na formulação do problema. 


\section{APLICAÇÃO}

\subsection{PREÂMBULO}

Nos próximos tópicos os conceitos de algoritmos genéticos serão aplicados para a resolução do problema apresentado no capítulo anterior. A partir deste ponto será adotada uma nova nomenclatura para as questões vinculadas ao problema. Esta nomenclatura visa fazer uma analogia entre o problema e o $A G$, conforme se observa na Figura 16.

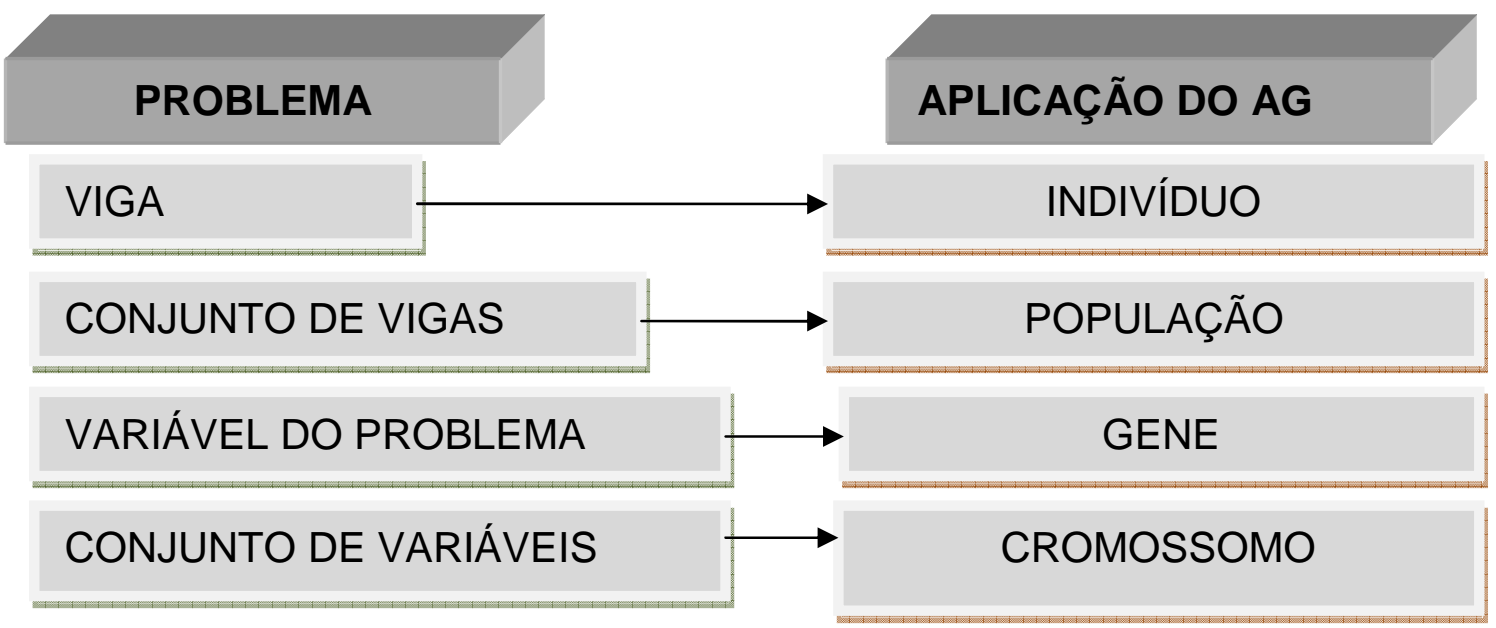

Figura 16 - Analogia: Problema x Algoritmo Genético

Uma viga (qualquer solução viável ou não do domínio de soluções do problema) será denominada indivíduo. Um conjunto de soluções, ou seja, um conjunto de vigas será denominado população. As variáveis aqui codificadas foram denominadas genes. Um conjunto de genes forma um cromossomo que representa uma viga. 


\subsection{REPRESENTAÇÃO E CODIFICAÇÃO}

Uma viga é representada por um cromossomo de 56 bits, conforme se pode observar na Figura $17^{6}$ :

Cromossomo Viga (56 bits)

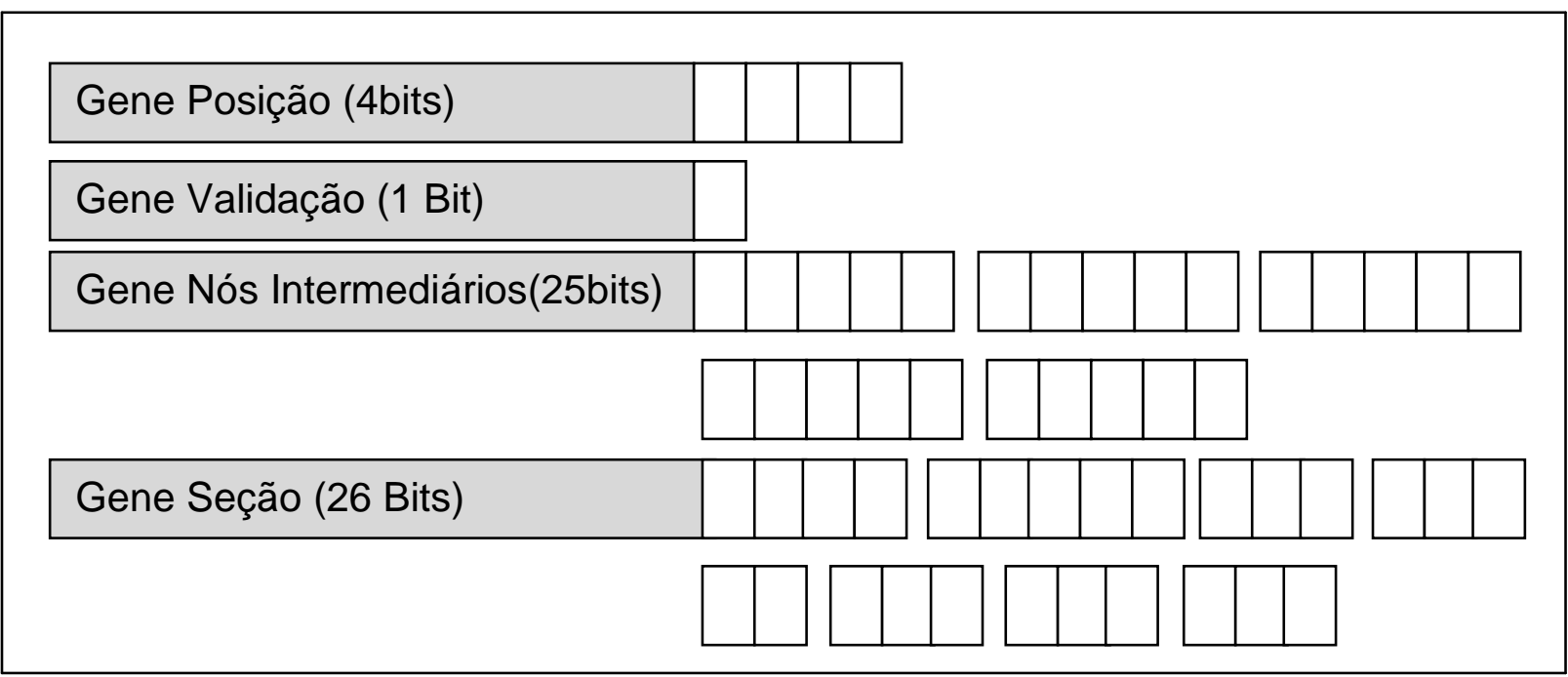

Figura 17 - Representação do cromossomo de uma viga

A seguir os genes do cromossomo viga são apresentados com mais detalhes:

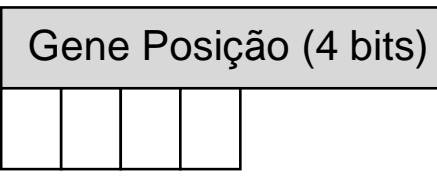

Posição que a viga ocupa no projeto do pavimento tipo. (Ver nota 6)

\footnotetext{
${ }^{6}$ Os genes posição e validação, só serão utilizados nos casos em que tratam de todo um pavimento. Para a aplicação do $A G$ entre vigas de uma mesma posição eles são irrelevantes, conforme informado no item 6.1 do Capítulo 6.
} 


\section{Gene Validação (1 Bit)}

Verifica a existência da viga. O valor "0" (zero) significa a ausência de viga naquela posição, o valor "1" (um) significa presença. (Ver nota 6)

\section{Gene Nos Intermediários (25bits)}

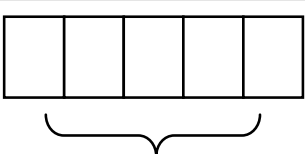

Nó 1

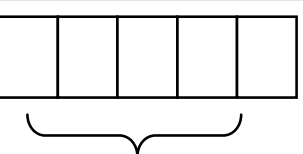

Nó 2

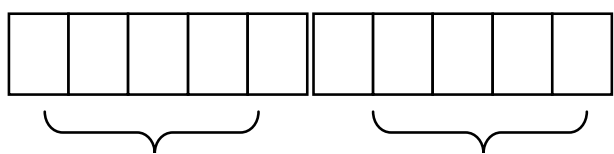

Nó 3

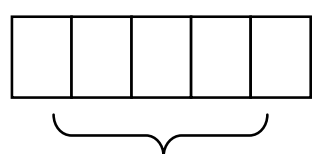

Nó 5

Formado por 25 Bits divididos em grupos de cinco. Cada grupo representa um nó intermediário da viga. Os números dos nós são expressos em binário. Caso o nó não exista na viga os bits do grupo são preenchidos por zero.

Gene Seção (26 Bits)

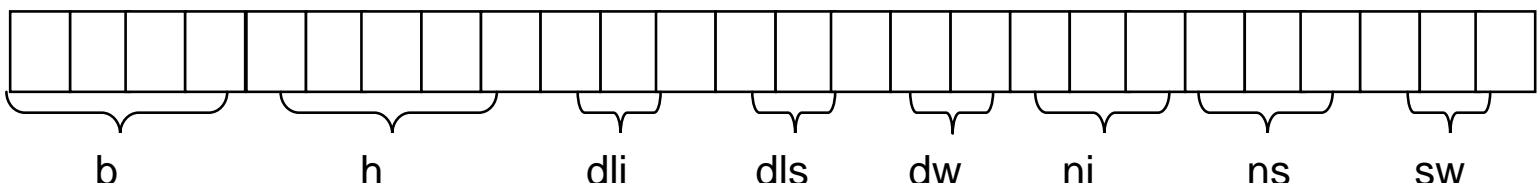

O gene seção de uma viga possui 26 Bits. Ele é formado por doze grupos que correspondem às variáveis paramétricas do projeto (Ver Figura 13), são elas: base (b), altura (h), diâmetro da armação longitudinal inferior (dli), diâmetro da armação longitudinal superior (dls), diâmetro dos estribos (dw), quantidade de barras longitudinais inferiores (ni), quantidade de barras longitudinais superiores (ns) e espaçamento entre estribos (sw). Todos codificados em binário e conforme limites apresentados no capitulo anterior. 


\subsection{PENALIZAÇÕES}

A fim de tornar o problema compatível com as suas restrições adotou-se o método das penalizações para que a função objetivo seja punida cada vez que algum critério não seja atendido.

São penalizados os elementos que não obedecem aos critérios de resistência (Ver item 6.4.1). Adotou-se a seguinte função de penalização:

$$
K=\sum_{i=1}^{2} \mu * \operatorname{máx}\left[0, g_{i}\right]
$$

\section{Equação 12 - Função de Penalização}

Onde:

$\mu=10000$

$g_{1}=\left[\left|\frac{M_{S D}^{+}}{M_{R D}^{+}}\right|-1\right]$

$g_{2}=\left[\left|\frac{M_{S D}^{-}}{M_{R D}^{-}}\right|-1\right]$

Sendo assim, à função que determina o custo unitário de cada viga é acrescentada a função de penalização:

$$
C_{v, m}{ }^{*}=C_{v, m}+K
$$

\section{Equação 13 - Custo Líquido da viga}

A esta função nomeou-se custo líquido de uma viga. Correspondendo ao real custo unitário de uma viga que será levado em consideração no processo de otimização da população. $O$ valor de $\mu$ foi determinado após inúmeros testes para calibração de parâmetros (Ver Capítulo 9). 


\subsection{ADEQUAÇÃO}

A fim de facilitar na implementação do processo de seleção (apresentado no tópico 7.5 deste capítulo) foi utilizado o conceito de adequação. A adequação, em algoritmos genéticos, corresponde ao inverso do custo líquido, ou seja:

$$
A_{i}=\frac{1}{C_{v, m}{ }^{*}}
$$

\section{Equação 14 - Adequação}

Onde:

$A_{i}=$ Adequação do indivíduo i ;

$C_{v, m}{ }^{*}=$ Custo líquido do indivíduo i, calculado conforme Equação 13;

Este recurso é utilizado apenas com a finalidade de tornar a seleção mais clara. O indivíduo que tiver maior valor de adequação terá maiores chances de ser selecionado.

\subsection{CRITÉRIOS DE SELEÇÃO}

Utilizou-se como método para a seleção dos indivíduos o método da roleta, proposto inicialmente por Holland.

O processo de seleção se inicia fazendo-se uma conversão do valor da adequação do indivíduo para graus. Para demonstração do processo, tomemos como exemplo a seguinte população composta por 10 indivíduos, com seus respectivos custos líquidos e adequação: 


\begin{tabular}{|c|c|c|}
\hline Indivíduo & Custo Líquido (Aptidão) - (R\$) & Adequação $\left.{ }^{*} 10^{-4} / \mathrm{R} \$\right)$ \\
\hline Viga 1 & 1859,55 & 5,377645 \\
\hline Viga 2 & 3500,78 & 2,856506 \\
\hline Viga 3 & 2345,25 & 4,263938 \\
\hline Viga 4 & 838,31 & 11,928761 \\
\hline Viga 5 & 4397,34 & 2,274102 \\
\hline Viga 6 & 2500,76 & 3,998784 \\
\hline Viga 7 & 3700,98 & 2,701987 \\
\hline Viga 8 & 1580,43 & 6,327392 \\
\hline Viga 9 & 5100,88 & 1,960446 \\
\hline Viga 10 & 1300,05 & 7,692012 \\
\hline
\end{tabular}

Tabela 2 - População X Custo Líquido X Adequação

Adaptar as adequações em graus significa dar a cada indivíduo da população um valor correspondente a um número em graus a fim de representar a faixa da roleta pertencente a cada um.

$$
A_{i, g}=\frac{360 * A_{i}}{\sum_{k=1}^{n} A_{k}}
$$

Equação 15- Adequação em graus

Onde

$A_{i, g}=$ Adequação do individuo i em graus; 
$A_{i}=$ Adequação do indivíduo i;

$\mathrm{n}$ = número total de indivíduos.

Neste caso perde-se um pouco da precisão, mas esta perda é irrelevante. Ao se trabalhar em graus, optou-se por usar números inteiros tendo em vista que o "ponteiro" que irá "girar" na roleta será um inteiro. Esta técnica pode ser facilmente modificada para uma mais precisa, basta utilizar um ponteiro com a quantidade de casas decimais que se deseja, porém, para este caso não será necessário. Abaixo se observa a adequação em graus correspondente a cada individuo.

\begin{tabular}{|c|c|c|c|}
\hline Indivíduo & Custo Líquido (Aptidão) - (R\$) & $\begin{array}{c}\text { Adequação } \\
\left({ }^{*} 10^{-4} / \mathrm{R} \$\right)\end{array}$ & $\begin{array}{c}\text { Adequação em } \\
\text { graus }\end{array}$ \\
\hline Viga 1 & 1859,55 & 5,377645 & $39^{\circ}$ \\
\hline Viga 2 & 3500,78 & 2,856506 & $21^{\circ}$ \\
\hline Viga 3 & 2345,25 & 4,263938 & $31^{\circ}$ \\
\hline Viga 4 & 838,31 & 11,928761 & $87^{\circ}$ \\
\hline Viga 5 & 4397,34 & 2,274102 & $17^{\circ}$ \\
\hline Viga 6 & 2500,76 & 3,998784 & $29^{\circ}$ \\
\hline Viga 7 & 3700,98 & 2,701987 & $20^{\circ}$ \\
\hline Viga 8 & 1580,43 & 6,327392 & $46^{\circ}$ \\
\hline Viga 9 & 5100,88 & 1,960446 & $14^{\circ}$ \\
\hline Viga 10 & 1300,05 & 7,692012 & $56^{\circ}$ \\
\hline
\end{tabular}




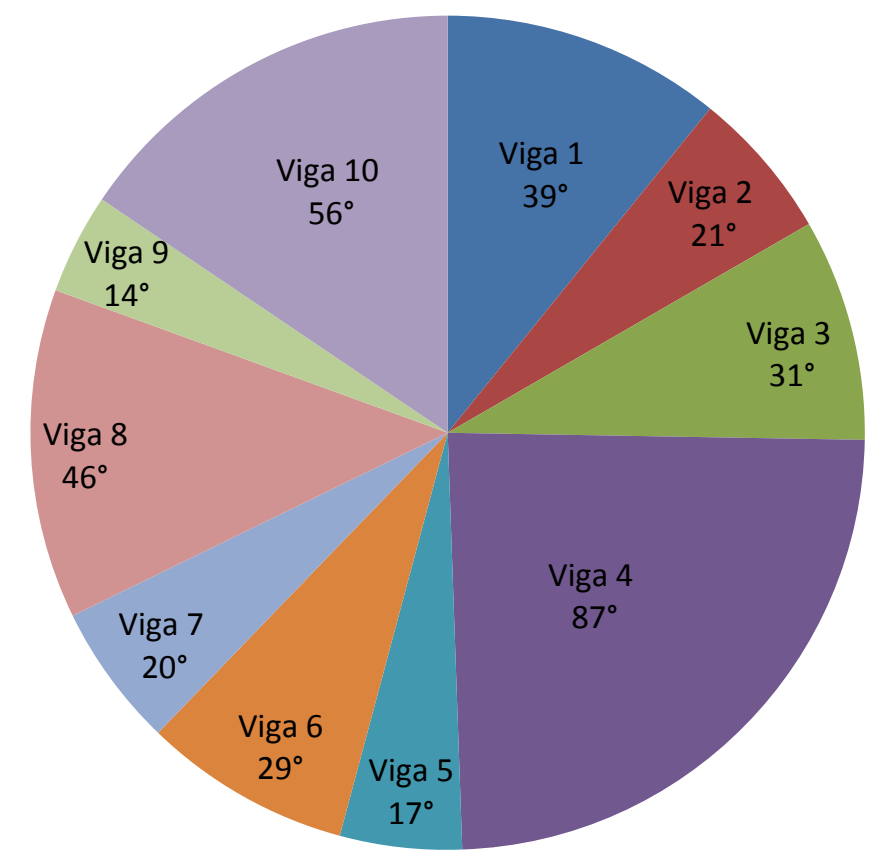

Gráfico 1 - Probabilidade de Seleção das Vigas (Adequação em Graus)

Em seguida, com base nesta adequação cada indivíduo recebe um valor correspondente as somas parciais da adequação em graus, ou seja:

\begin{tabular}{|c|c|c|}
\hline Indivíduo & $\begin{array}{c}\text { Adequação em } \\
\text { graus }\end{array}$ & $\begin{array}{c}\text { Somas } \\
\text { Parciais }\end{array}$ \\
\hline Viga 1 & $39^{\circ}$ & $39^{\circ}$ \\
\hline Viga 2 & $21^{\circ}$ & $60^{\circ}$ \\
\hline Viga 3 & $31^{\circ}$ & $91^{\circ}$ \\
\hline Viga 4 & $87^{\circ}$ & $178^{\circ}$ \\
\hline Viga 5 & $17^{\circ}$ & $195^{\circ}$ \\
\hline
\end{tabular}




\begin{tabular}{|c|c|c|}
\hline Indivíduo & $\begin{array}{c}\text { Adequação em } \\
\text { graus }\end{array}$ & $\begin{array}{c}\text { Somas } \\
\text { Parciais }\end{array}$ \\
\hline Viga 6 & $29^{\circ}$ & $224^{\circ}$ \\
\hline Viga 7 & $20^{\circ}$ & $244^{\circ}$ \\
\hline Viga 8 & $46^{\circ}$ & $290^{\circ}$ \\
\hline Viga 9 & $14^{\circ}$ & $304^{\circ}$ \\
\hline Viga 10 & $56^{\circ}$ & $360^{\circ}$ \\
\hline
\end{tabular}

Tabela 4 - Somas Parciais

São estas somas parciais indicadas a cada indivíduo que irão servir como parâmetro de seleção por roleta. Simula-se então a roleta, gerando-se um número aleatoriamente entre 0 e 360 . O indivíduo que contiver a faixa na qual o número gerado se encontra é o que será selecionado. Por exemplo, digamos que o número gerado aleatoriamente tenha sido o número 71 . 0 indivíduo selecionado então seria o indivíduo 3, pois ele contem a faixa entre os números 61 e 91 . Este passo é então executado o número de vezes correspondente ao tamanho da população (tendo em vista que o programa implementado mantêm a população sempre com um tamanho fixo). Fazendo-se uma simulação para este exemplo, temos:

\begin{tabular}{|c|c|}
\hline Ponteiro & Indivíduo Selecionado \\
\hline 222 & Viga 6 \\
\hline 153 & Viga 4 \\
\hline 35 & Viga 1 \\
\hline 164 & Viga 4 \\
\hline
\end{tabular}




\begin{tabular}{|c|c|}
\hline Ponteiro & Indivíduo Selecionado \\
\hline 155 & Viga 4 \\
\hline 110 & Viga 4 \\
\hline 324 & Viga 10 \\
\hline 170 & Viga 4 \\
\hline 242 & Viga 7 \\
\hline 174 & Viga 4 \\
\hline
\end{tabular}

Tabela 5- Indivíduos Selecionados

Pode-se notar claramente que a Viga 4 conseguiu mais posições no grupo de indivíduos selecionados para o cruzamento. Após a seleção, os indivíduos são então tomados dois a dois para o cruzamento.

\subsection{CRUZAMENTO}

A técnica de cruzamento utilizada é uma adaptação do cruzamento multiponto (ver item 5.6 do Capítulo 0). Os genes posição e validação não são cruzados. São apenas utilizados para identificar a posição e existência de uma viga (ver nota 6).

Os genes que realmente participam do cruzamento são: o gene "Nós Intermediários" (otimização topológica) e o gene "Seção" (otimização paramétrica).

O cruzamento é feito separando-se cada grupo de um gene e verificando se eles serão ou não trocados. Por exemplo, sejam os genes "Seção" apresentados abaixo: 
Gene Seção (A)

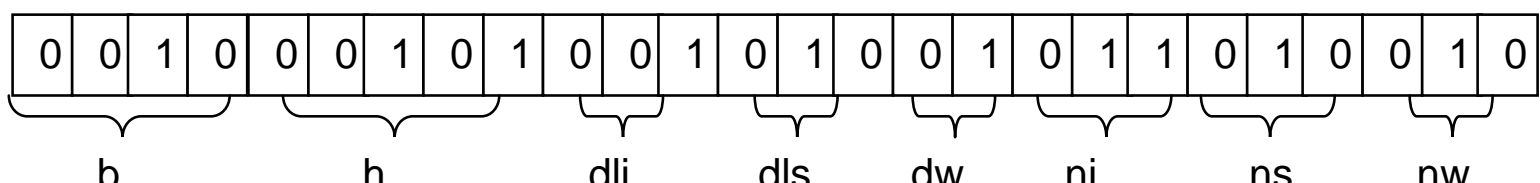

b

$\mathrm{h}$ dli dls $\mathrm{dw}$

ni ns

nW

Gene Seção (B)

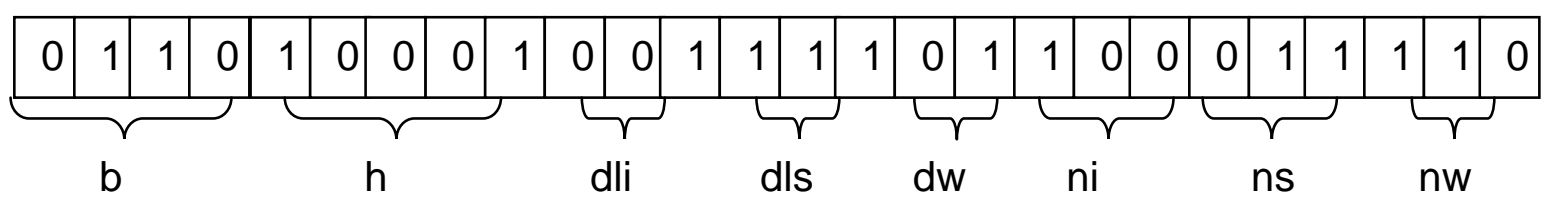

Cada grupo do gene (que corresponde a uma variável) é percorrido. Sorteia-se então um valor que pode ser 0 ou 1. Caso dê zero este grupo não será trocado, caso contrário ele será trocado. Sendo assim, cada variável tem $50 \%$ de chance de ser trocada. O mesmo ocorre para o gene nós intermediários. Ao final resultam dois indivíduos com características mistas dos dois indivíduos genitores.

\subsection{MUTAÇÃO}

No programa implementado a mutação ocorre segundo uma probabilidade de mutação definida pelo usuário. Após muitos testes verificou-se que adotar uma probabilidade de mutação o inverso do tamanho da população é um bom parâmetro, e, portanto, para os testes ele passou a ser adotado. Adotar um determinado valor que não relacionava o tamanho da população resultava em um comportamento inadequado do programa quando se tratava de uma população muito grande ou pequena demais. Quando a população era pequena a mutação fazia com que a busca fosse apenas aleatória. Quando a população era grande demais ela não fazia diferença significativa. 
Na primeira fase deste trabalho, antes da adoção da mutação como uma operação do AG tinha-se muitos problemas de mínimos locais. Ou seja, o programa convergia rapidamente para um mínimo local. Com a adoção de uma taxa de mutação notouse que a população ficou mais diversificada resolvendo o problema anterior.

\subsection{ELITISMO}

Adotou-se como técnica de elitismo a substituição do pior indivíduo da geração atual pelo melhor indivíduo da geração anterior. Assim, procurou-se não perder um individuo com boas características. 


\section{ESTRUTURA DO AGEN}

\subsection{PREAMBULO}

Conforme explicado anteriormente, a proposta inicial desta dissertação era fazer otimização de pavimentos tipo de edifícios, utilizando os AG's. Portanto ficam válidas as mesmas observações aferidas no tópico 6.1 do capítulo 6 deste trabalho. Apesar de não concluído em sua totalidade muito se foi feito a fim de atingir esse objetivo e será também apresentado nos próximos tópicos. Como o programa foi elaborado utilizando uma abordagem orientada a objetos (POO - Programação Orientada a Objetos $^{7}$ ), que se baseia na abstração e independência de várias etapas de um projeto, muita fases puderam ser desenvolvidas separadamente, sem que isso implicasse em uma dependência de outras etapas inacabadas.

O objetivo deste capítulo não é apresentar linhas de código do programa. Pretendese apenas mostrar uma visão geral na forma como ele foi desenvolvido e apresentar suas principais classes e relacionamentos. As classes inacabadas serão indicadas.

\subsection{APRESENTAÇÃO GERAL}

O programa é capaz de: dada uma viga com seu nó inicial, nó final e possíveis nós intermediários, fazer otimização topológica e paramétrica da mesma utilizando, para isso, algoritmos genéticos. As restrições laterais e de comportamento adotadas, bem como a função objetivo e de penalização já foram introduzidas em capítulos anteriores.

\footnotetext{
${ }^{7}$ Para mais detalhes sobre POO recomenda-se o livro: "Head First Object Oriented Analysis \& Design" de Brett D. McLaughlin, Gary Pollice e Dave West.
} 
$O \mathrm{AGEN}^{8}$ foi desenvolvido na linguagem Java. Ele encontra-se organizado em pacotes. A tabela abaixo apresenta seus principais pacotes e classes:

\begin{tabular}{|c|c|c|c|}
\hline \multicolumn{4}{|c|}{ AGEN } \\
\hline PACOTE & AG & ESTRUTURA & MAPEAMENTO \\
\hline $\begin{array}{l}\text { PRINCIPAIS } \\
\text { CLASSES }\end{array}$ & $\begin{array}{l}\text { - Aleatório } \\
\text { - AlgenVigas } \\
\text { - AlgenPavimentos } \\
\text { (Incompleto) } \\
\text { - CromossomoViga } \\
\text { - GeneArmadura } \\
\text { - GeneNosInt } \\
\text { - GenePosicao } \\
\text { - GeneSecaoConcreto } \\
\text { - Individuo } \\
\text { (Incompleto) } \\
\text { - RibossomoViga }\end{array}$ & $\begin{array}{l}\text { - Projeto } \\
\text { (Incompleto) } \\
\text { - Viga } \\
\text { - VigaConcreto } \\
\text { - AeVigas } \\
\text { CARACTERÍsTICAS } \\
\text { - Seção } \\
\text { O Retangular } \\
\text { ○ Circular } \\
\text { ○ Bitola } \\
\text { ○ Perfill } \\
\text { - Armadura } \\
\text { - Material } \\
\text { ○ Aco } \\
\text { ○ Concreto } \\
\text { - ListaDeSecoes } \\
\text { - ListaDeMateriais }\end{array}$ & $\begin{array}{l}\text { - Mapa } \\
\text { - MapaCompleto } \\
\text { - MapeamentoViga }\end{array}$ \\
\hline
\end{tabular}

Tabela 6 - Principais pacotes e classes do AGEN

\footnotetext{
${ }^{8}$ Nome dado ao programa implementado.
} 


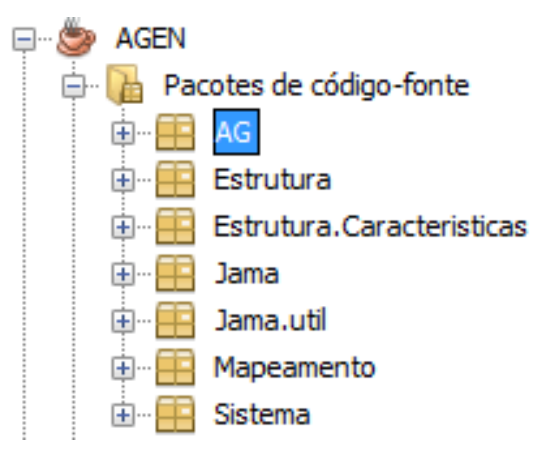

Figura 18 - Estrutura do AGEN

Abaixo são descritos sucintamente os principais pacotes:

- Pacote AG: Contem as classes que implementam o algoritmo genético;

- Pacote Estrutura: possui as classes que caracterizam e fazem a análise estrutural das estruturas do programa.

- Pacote Estrutura.Características: é um sub pacote do pacote estrutura que possui classes auxiliares que descrevem as características dos elementos.

- Pacote Mapeamento: possui o mapeamento dos nós do problema a ser resolvido.

- Pacote Sistema: é onde se encontra a classe principal e faz a ligação de todas as partes do programa, através de uma interface gráfica.

Nos próximos tópicos estes pacotes serão apresentados com maiores detalhes. É importante destacar que para manipulação de matrizes utilizou-se o pacote de álgebra linear Jama, elaborado pela MathWorks e pelo NIST (National Institute of Standards and Technology). 


\subsection{PACOTE AG}

Abaixo é apresentado o diagrama de classes (simplificado) do pacote AG:

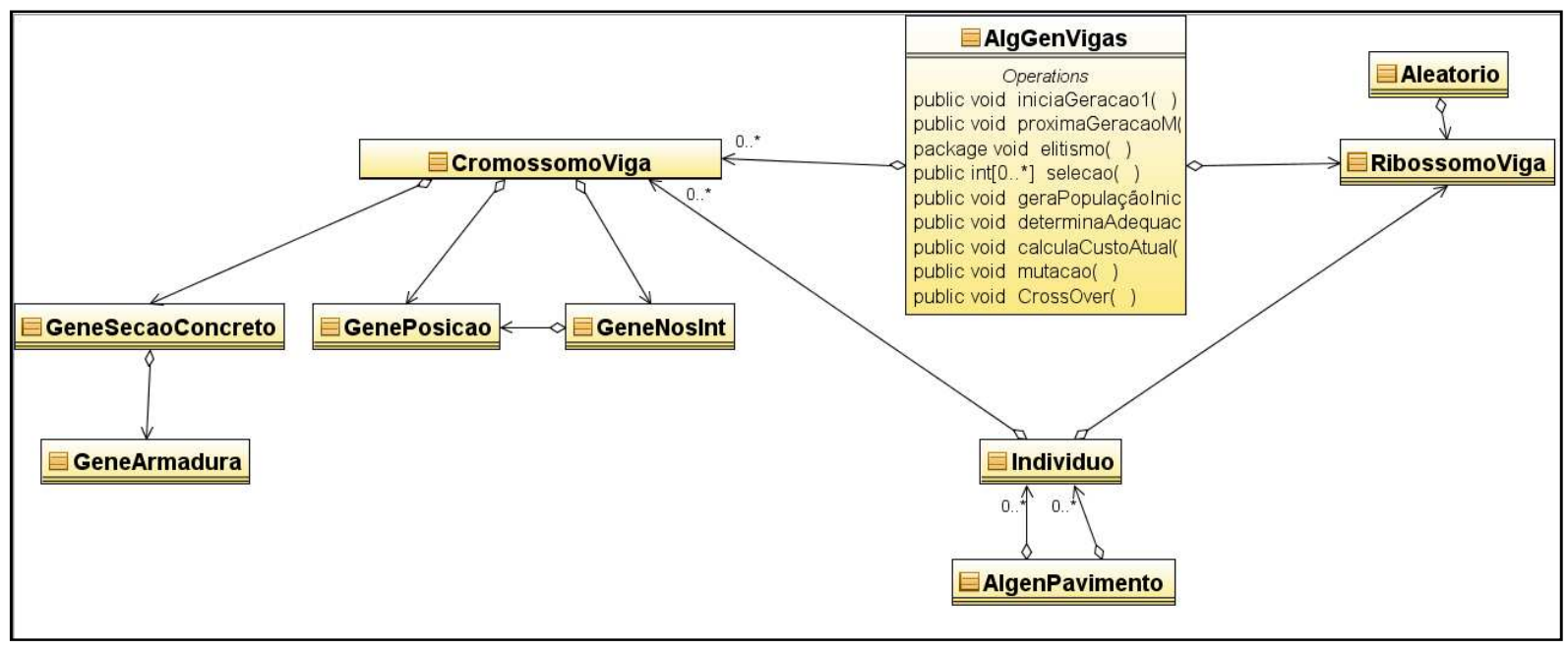

Figura 19 - Diagrama de Classes Simplificado do Pacote AG

\begin{tabular}{|c|c|}
\hline \\
\hline \multicolumn{2}{|c|}{ : } \\
\hline 60 & AlgGenVigas.java \\
\hline$\omega^{\circ}$ & AlgenPavimento.java \\
\hline 10 & Binario.java \\
\hline (1) & CromossomoViga.java \\
\hline 여 & CrossOver.java \\
\hline 영 & GeneArmadura.java \\
\hline 80 & GeneNosint.java \\
\hline Bمी & GenePosicao.java \\
\hline ... & GeneSecaoConcreto.java \\
\hline ... & Individuo.java \\
\hline .... & RibossomoViga.java \\
\hline
\end{tabular}

Figura 20 - Pacote AG 
As seguintes classes o compõem:

- Aleatório: Cria cromossomos de vigas aleatoriamente.

- AlgGenVigas: Classe que implementa o algoritmo genético propriamente dito, para vigas.

- AlgenPavimento: Classe que implementa o algoritmo genético para pavimentos (Incompleto)

- Binário: Classe que caracteriza o tipo binário, que é a base para a codificação do cromossomo.

- CromossomoViga: caracteriza o cromossomo de uma viga. Ele é composto pelas classes: GeneArmadura, GeneMaterial, GeneNosInt, GenePosicao e GeneSecao.

- CrossOver: classe que faz o crossover entre as vigas.

- GeneArmadura: caracteriza a armadura de uma viga, codificada em binário.

- GeneMaterial: caracteriza o material de uma viga, codificado em binário.

- GeneNosInt: possui a informação dos nós intermediários da viga, codificados em binário.

- GenePosicao: caracteriza a posição da viga, codificada em binário.

- GeneSeçãoConcreto: caracteriza a seção transversal das vigas de concreto, codificada em binário. 
- RibossomoViga: classe auxiliar que codifica e decodifica os genes dos cromossomos das vigas.

\subsection{PACOTE ESTRUTURA}

O diagrama de classes simplificado do pacote estrutura é apresentado abaixo:

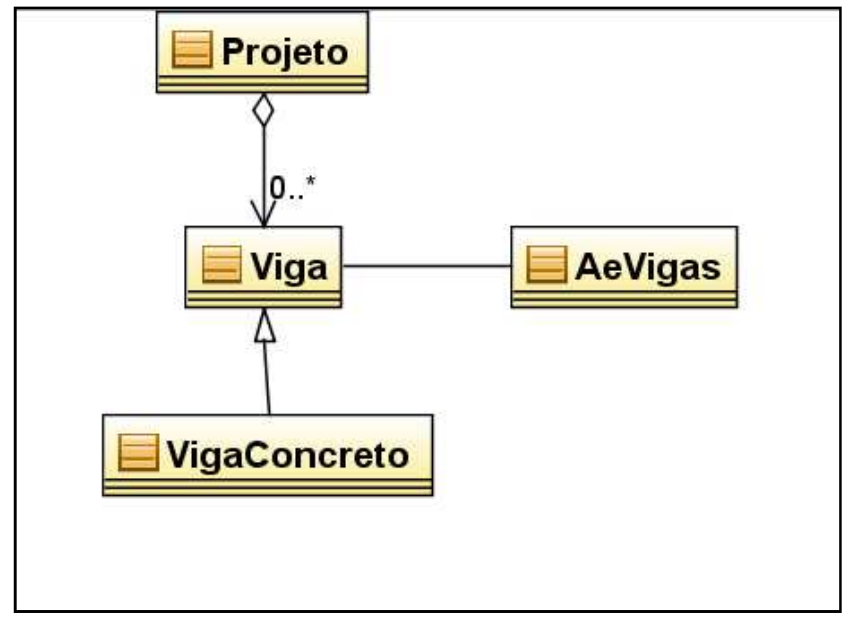

Figura 21 - Diagrama de classes simplificado do pacote Estrutura

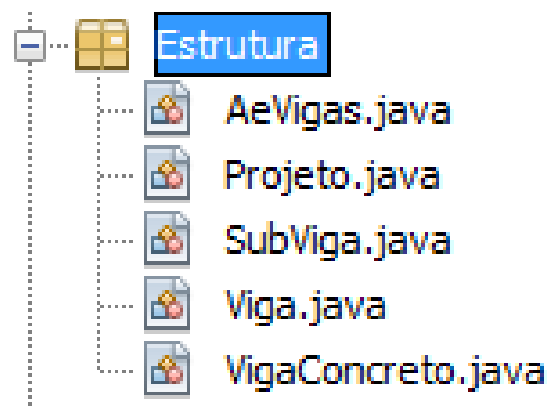

Figura 22 - Pacote Estrutura 
- AeVigas: Faz a análise estrutural de vigas;

- SubViga: É utilizada para auxiliar no cálculo da análise de uma viga contínua.

- Viga: Classe que caracteriza uma viga genérica.

- VigaConcreto: Caracteriza uma viga de concreto;

\subsubsection{SUBPACOTE ESTRUTURA.CARACTERISTICAS}

O pacote Estrutura.Características é na verdade um sub pacote do pacote Estrutura. Ele é utilizado para definir as características dos materiais e seção transversal das estruturas utilizadas pelo pacote estrutura. Seu diagrama de classes simplificado é apresentado abaixo:

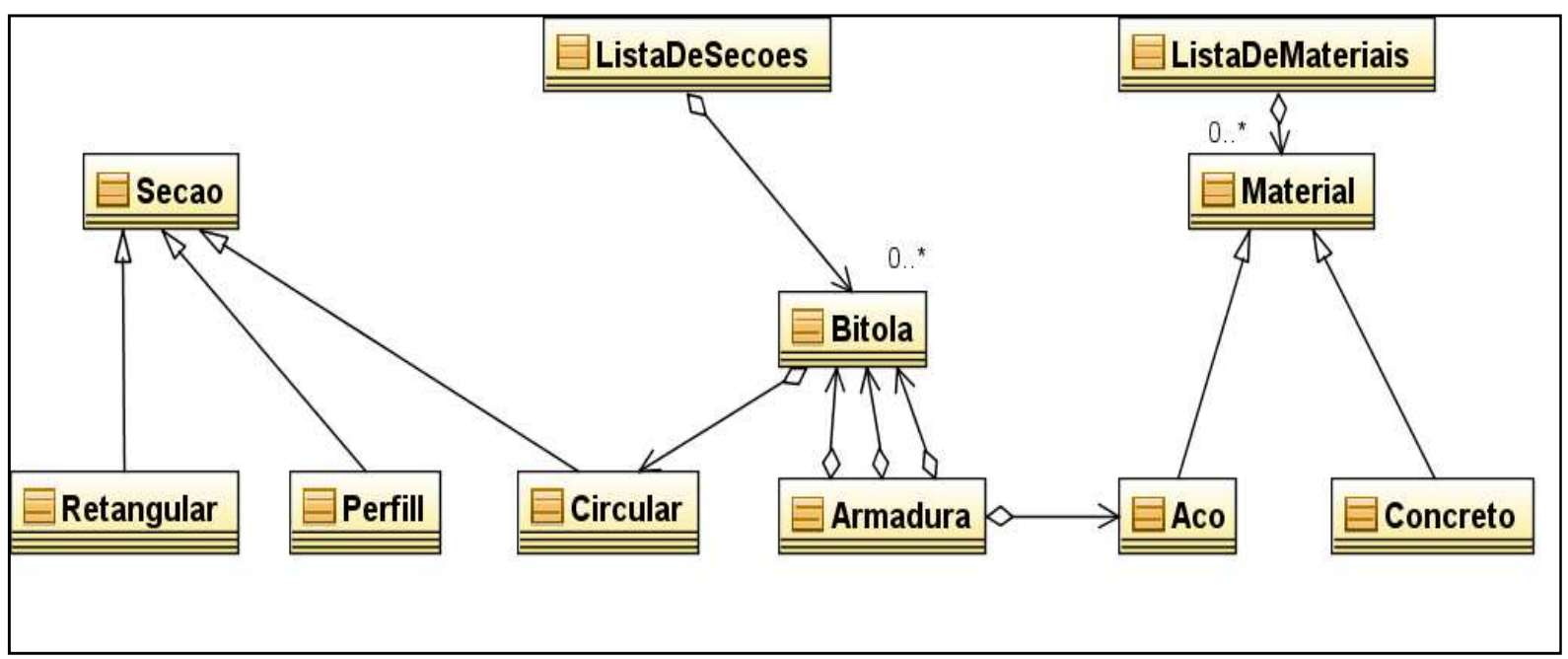

Figura 23 - Diagrama de Classes simplificado do pacote Estrutura.características 


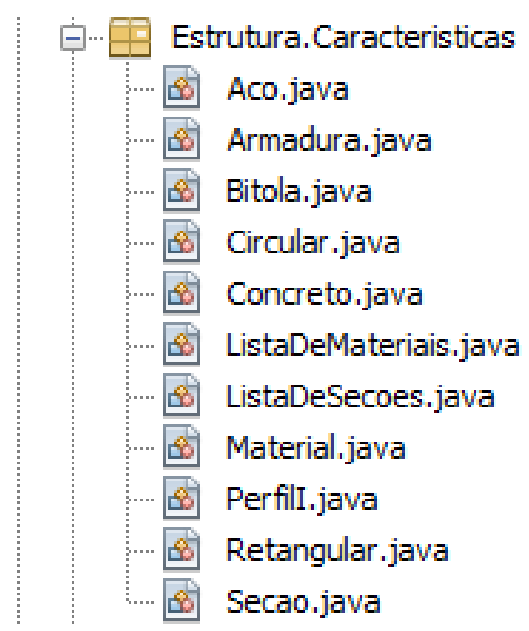

Figura 24 - Sub Pacote Estrutura.Características

Ele é composto pelas seguintes classes:

- Secao: caracteriza uma seção transversal. Ela pode ser circular, retangular, perfil I, etc.

- Perfill ${ }^{9}$ : caracteriza uma seção transversal tipo perfil l;

- Retangular: caracteriza uma seção transversal retangular;

- Circular: define uma seção circular;

- Bitola: define uma bitola de aço;

- Armadura: Define a armadura de uma viga de concreto, com sua armadura longitudinal inferior, longitudinal superior e estribos;

- Material: Caracteriza um material;

- Concreto: Define um material de concreto;

\footnotetext{
${ }^{9}$ Inicialmente o tipo de material da viga (concreto ou aço) também entrava como variável e os tipos de vigas metálicas que se utilizava eram perfis I. Com os testes viu-se que nunca os perfis metálicos conseguiam ser solução do problema (devido ao custo elevado), portanto eles foram removidos da formulação do problema. Pode-se trazê-lo facilmente de volta ao programa e torná-los competitivos; o fator praticidade e rapidez, se entrados na função objetivo favoreceriam o perfil metálico.
} 
- Aço: Define o material aço;

- ListaDeMateriais: guarda uma lista de materiais que é utilizada no programa.

- ListadeSecoes: Guarda uma lista de seções transversais utilizadas no programa;

\subsection{PACOTE MAPEAMENTO}

O pacote mapeamento, como o próprio nome diz, possui guardado o mapeamento dos nós do problema. É inerente a cada problema analisado. Ele é formado pelas seguintes classes:

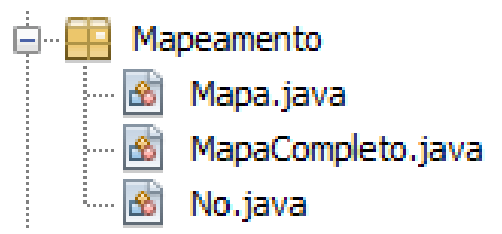

Figura 25 - Pacote Mapeamento

- Mapa: caracteriza o mapa de um indivíduo. Ou seja, guarda os nós válidos de projeto/vigas.

- MapaCompleto: possui o mapeamento de todos os nós que um indivíduo pode ter.

- No: caracteriza um nó (coordenadas x e y) no MapaCompleto. 


\subsection{PACOTE SISTEMA}

O pacote sistema é o que possui a classe main (classe principal) que faz a ligação entre os pacotes do programa. Além disso, é no pacote Sistema que se encontra a classe que trata da interface gráfica do programa.

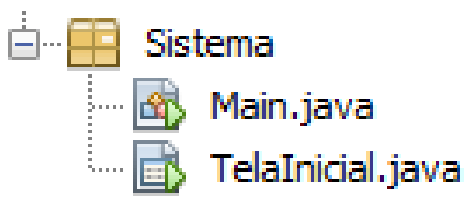

Figura 26 - Pacote Sistema

- main: classe principal do programa. É a que é inicializada primeiro e que interliga as demais classes.

- Telalnicial: Interface gráfica do programa. 


\section{TESTES E CALIBRAGEM DE PARÂMETROS}

\subsection{PREAMBULO}

Para validar o programa apresentado anteriormente fez-se necessário que ele fosse aplicado a um caso já tratado pela literatura, onde seus resultados já fossem conhecidos, a fim de se poder ter parâmetros de comparação quanto à sua funcionalidade. No apêndice A, é apresentada uma aplicação do programa AGEN em um problema tratado por dois autores, com duas abordagens distintas. Um autor utilizou abordagem determinística enquanto o segundo adotou uma abordagem probabilística, utilizando algoritmos genéticos, porém em ambos os casos as variáveis eram contínuas. Em $85 \%$ dos testes realizados o programa (AGEN) encontrou a solução ótima. Pode-se considerar uma boa taxa de aprovação, tendo em vista que os algoritmos genéticos, bem como os demais métodos evolucionários, não garantem $100 \%$ de resultado. Como se trata de um método probabilístico existem alguns fatores que fazem com que o algoritmo não convirja, ou convirja para um mínimo local. Parâmetros como: tamanho da população, tamanho do cromossomo, taxa de mutação, número máximo de gerações, critérios de parada, população inicial, função de penalização entre outros são fatores que se verificou que influenciavam bastante para o bom funcionamento do programa. Assim como um instrumento novo que precisa ser afinado, o AG, por ser um método genérico, também precisa de uma calibragem de seus parâmetros. Tendo em vista que cada caso é um caso.

Para demonstrar a influencia destes critérios, foram realizados testes onde se variava um parâmetro em específico, mantendo outros fixos. Estes testes serão apresentados nos próximos tópicos. Para cada teste o programa foi aplicado 10 vezes.

Os testes, a título de exemplo, foram realizados em uma viga, conforme configuração abaixo ( $L=14.5 \mathrm{~m}$ e $q=2 \mathrm{t} / \mathrm{m})$ : 


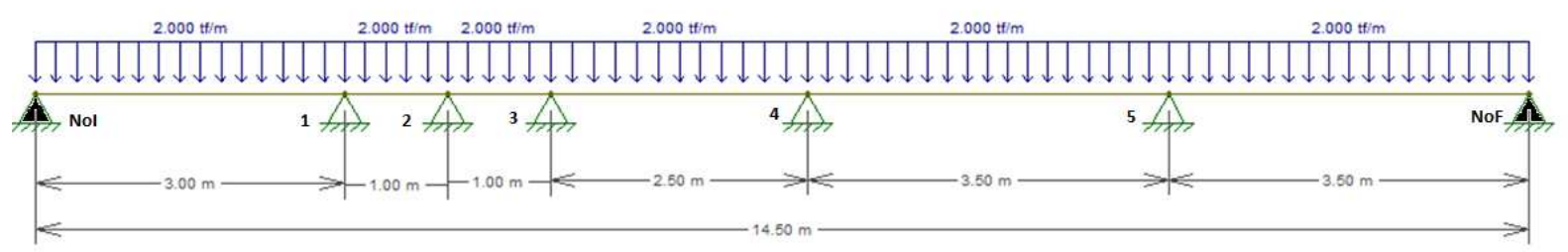

Figura 27 - Configuração da viga exemplo

A função objetivo, bem como as restrições laterais e de comportamento são conforme apresentado em capítulos anteriores.

Nas tabelas que serão apresentadas a seguir, adotou-se a seguinte nomenclatura para a coluna "Parada" (Sobre o critério de parada do programa):

GXX-PH - Significa que ele parou na geração XX devido ao fato da população ter ficado homogênea $(\mathrm{PH})$.

GXX-MG - Significa que ele parou na geração XX devido ao fato da população ter alcançado o número máximo de gerações permitidas.

\subsection{TAMANHO DA POPULAÇÃO - TESTE 1}

Neste teste, o tamanho da população será variado conforme indicado abaixo:

\begin{tabular}{|c|c|}
\hline TESTE & $\begin{array}{l}\text { TAMANHO DA } \\
\text { POPULAÇÃO }\end{array}$ \\
\hline $1 \mathrm{~A}$ & 10 \\
\hline $1 \mathrm{~B}$ & 100 \\
\hline $1 \mathrm{C}$ & 1000 \\
\hline $1 \mathrm{D}$ & 10000 \\
\hline
\end{tabular}


Parâmetros fixos:

- Número máximo de gerações: 100;

- Mutação: 1/(tamanho da população);

- Penalização: Conforme Equação 12 ( $\mu=10000)$.

- Critério de parada: Número máximo de gerações ou a população ficar homogênea ${ }^{10}$.

Os resultados obtidos encontram-se nas tabelas abaixo.

\begin{tabular}{|c|c|c|c|c|c|c|c|}
\hline \multicolumn{8}{|c|}{ TESTE 1A } \\
\hline № & $\begin{array}{c}\text { NÓS } \\
\text { INTERM. }\end{array}$ & $\begin{array}{l}\text { BASE } \\
\text { (cm) }\end{array}$ & $\begin{array}{c}\text { ALTURA } \\
\text { (cm) }\end{array}$ & As & As' & $\mathbf{R} \mathbf{\$}$ & PARADA \\
\hline 1 & 1,4 & 55 & 50 & $3 \phi 16$ & $4 \phi 20$ & 1861,99 & G3 - PH \\
\hline 2 & 1,4 & 20 & 145 & $4 \phi 12,5$ & $4 \phi 20$ & 2202,65 & $\mathrm{G} 8-\mathrm{PH}$ \\
\hline 3 & 2 & 75 & 110 & $7 \phi 25$ & $7 \phi 16$ & 4940,51 & $\mathrm{G} 4-\mathrm{PH}$ \\
\hline 4 & 2,4 & 40 & 90 & $3 \phi 25$ & $4 \phi 8$ & 3048,77 & $\mathrm{G} 2-\mathrm{PH}$ \\
\hline 5 & 2,4 & 55 & 110 & $7 \phi 10$ & $3 \phi 25$ & 3442,76 & $\mathrm{G} 12-\mathrm{PH}$ \\
\hline 6 & $1,2,3,4$ & 70 & 100 & $7 \phi 10$ & $7 \phi 10$ & 4208,25 & $\mathrm{G} 6-\mathrm{PH}$ \\
\hline 7 & 0 & 80 & 145 & $4 \phi 16$ & $7 \phi 10$ & 6171,13 & G3 - PH \\
\hline 8 & 1,4 & 30 & 75 & $2 \phi 25$ & $2 \phi 25$ & 1759,11 & G3 - PH \\
\hline 9 & $1,2,3,4$ & 30 & 165 & $7 \phi 10$ & $7 \phi 10$ & 3401,29 & $\mathrm{G} 2-\mathrm{PH}$ \\
\hline 10 & 3,4 & 60 & 35 & $7 \phi 20$ & $7 \phi 20$ & 1877,09 & $\mathrm{G} 4-\mathrm{PH}$ \\
\hline \multicolumn{7}{|c|}{ MÉDIA (R\$) } & 3291,36 \\
\hline
\end{tabular}

Tabela 7 - Teste $1 \mathrm{~A}$

${ }^{10}$ A população é considerada homogênea quando todos os seus indivíduos são iguais. 


\begin{tabular}{|c|c|c|c|c|c|c|c|}
\hline \multicolumn{8}{|c|}{ TESTE 1B } \\
\hline № & $\begin{array}{c}\text { NÓS } \\
\text { INTERM. }\end{array}$ & $\begin{array}{l}\text { BASE } \\
\text { (cm) }\end{array}$ & $\begin{array}{c}\text { ALTURA } \\
\text { (cm) }\end{array}$ & As & As' & $\mathbf{R} \$$ & PARADA \\
\hline 1 & 1,4 & 70 & 90 & $6 \phi 25$ & $6 \$ 20$ & 4169,38 & $\mathrm{G} 45-\mathrm{PH}$ \\
\hline 2 & $1,3,4$ & 40 & 150 & $7 \phi 10$ & $3 \phi 16$ & 3804,95 & $\mathrm{G} 45-\mathrm{PH}$ \\
\hline 3 & 1,2 & 25 & 85 & $5 \phi 25$ & $6 \phi 20$ & 2142,53 & $\mathrm{G} 45-\mathrm{PH}$ \\
\hline 4 & $1,3,4$ & 30 & 175 & $7 \phi 20$ & $2 \phi 12,5$ & 3560,67 & $\mathrm{G} 45-\mathrm{PH}$ \\
\hline 5 & 2,4 & 25 & 95 & $5 \phi 25$ & $5 \phi 12,5$ & 2153,32 & $\mathrm{G} 45-\mathrm{PH}$ \\
\hline 6 & 3,4 & 25 & 120 & $7 \phi 25$ & $5 \phi 25$ & 3185,03 & $\mathrm{G} 45-\mathrm{PH}$ \\
\hline 7 & 2,4 & 20 & 65 & $6 \phi 20$ & $7 \phi 25$ & 1985,23 & $\mathrm{G} 45-\mathrm{PH}$ \\
\hline 8 & 3,4 & 30 & 95 & $2 \phi 25$ & $6 \$ 16$ & 2304,02 & $\mathrm{G} 45-\mathrm{PH}$ \\
\hline 9 & 3,4 & 20 & 100 & $3 \phi 16$ & $4 \phi 12,5$ & 1605,29 & $\mathrm{G} 45-\mathrm{PH}$ \\
\hline 10 & $1,2,4$ & 25 & 135 & $4 \phi 25$ & $3 \phi 25$ & 2726,50 & $\mathrm{G} 45-\mathrm{PH}$ \\
\hline & & & & & & DIA (R\$) & 2763,69 \\
\hline
\end{tabular}

Tabela 8 - Teste 1B

\begin{tabular}{|c|c|c|c|c|c|c|c|}
\hline \multicolumn{8}{|c|}{ TESTE 1C } \\
\hline № & $\begin{array}{c}\text { NÓS } \\
\text { INTERM. }\end{array}$ & $\begin{array}{l}\text { BASE } \\
(\mathrm{cm})\end{array}$ & $\begin{array}{c}\text { ALTURA } \\
(\mathrm{cm})\end{array}$ & As & As' & $\mathbf{R} \$$ & PARADA \\
\hline 1 & $1,3,4$ & 35 & 85 & $5 \phi 25$ & $6 \phi 20$ & 2533,53 & G100-MG \\
\hline 2 & $1,3,4$ & 20 & 80 & $7 \phi 10$ & $7 \phi 12,5$ & 1373,56 & G100-MG \\
\hline 3 & 1,4 & 20 & 40 & $6 \phi 12,5$ & $4 \phi 12,5$ & 2715,51 & G48-PH \\
\hline 4 & 4 & 25 & 100 & $6 \phi 16$ & $7 \phi 12,5$ & 2151,80 & G100-MG \\
\hline 5 & $1,3,4$ & 25 & 145 & $6 \phi 25$ & $6 \phi 12,5$ & 3025,34 & G100-MG \\
\hline 6 & $2,3,4$ & 20 & 65 & $7 \phi 12,5$ & $4 \phi 20$ & 1329,76 & G90-PH \\
\hline 7 & $2,3,4$ & 20 & 75 & $5 \phi 16$ & $7 \phi 20$ & 1609,43 & G77-PH \\
\hline 8 & $2,3,4$ & 25 & 75 & $7 \phi 10$ & $4 \phi 20$ & 1544,93 & G87-PH \\
\hline 9 & $1,2,3,4$ & 20 & 120 & $3 \phi 12,5$ & $5 \phi 20$ & 2024,53 & G40-PH \\
\hline 10 & $2,3,4$ & 45 & 130 & $4 \phi 12,5$ & $4 \phi 12,5$ & 3372,16 & G100-MG \\
\hline \multicolumn{7}{|c|}{ MÉDIA (R\$) } & 2168,06 \\
\hline
\end{tabular}

Tabela 9 - Teste 1C 


\begin{tabular}{|l|r|r|r|r|r|r|r|}
\hline \multicolumn{7}{|c|}{ TESTE 1D } \\
\hline No & $\begin{array}{c}\text { NÓS } \\
\text { INTERM. }\end{array}$ & $\begin{array}{r}\text { BASE } \\
(\mathbf{c m})\end{array}$ & $\begin{array}{c}\text { ALTURA } \\
(\mathbf{c m})\end{array}$ & \multicolumn{1}{c|}{ As } & \multicolumn{1}{c|}{ As' } & R\$ & PARADA \\
\hline 1 & $2,3,4$ & 35 & 90 & $3 \phi 16$ & $3 \phi 20$ & 2202,19 & G67-PH \\
\hline 2 & $1,2,4$ & 25 & 160 & $3 \phi 10$ & $5 \phi 16$ & 2778,99 & G100-MG \\
\hline 3 & 1,4 & 25 & 100 & $5 \phi 25$ & $5 \phi 20$ & 2320,67 & G81-PH \\
\hline 4 & 3,4 & 30 & 155 & $7 \phi 12,5$ & $6 \phi 16$ & 3278,67 & G39-PH \\
\hline 5 & $2,3,4$ & 20 & 120 & $7 \phi 12,5$ & $4 \phi 20$ & 2095,88 & G100-MG \\
\hline 6 & $1,2,3,4$ & 25 & 145 & $6 \phi 20$ & $6 \phi 20$ & 2991,88 & G77-PH \\
\hline 7 & $2,3,4$ & 30 & 145 & $4 \phi 20$ & $3 \phi 20$ & 3249,14 & G86-PH \\
\hline 8 & 1,4 & 25 & 60 & $4 \phi 16$ & $7 \phi 12,5$ & 1378,63 & G51-PH \\
\hline 9 & 4 & 40 & 75 & $6 \phi 16$ & $6 \phi 20$ & 2316,74 & G100-MG \\
\hline 10 & 2,4 & 45 & 80 & $2 \phi 12,5$ & $7 \phi 12,5$ & 2378,42 & G100-MG \\
\hline & & & & & MÉDIA (R\$) & 2499,12 \\
\hline
\end{tabular}

Tabela 10 - Teste 1D

Pode-se notar que à medida que o tamanho da população vai aumentando, o programa vai convergindo para uma melhor solução. Até que se chega a um ponto em que este ganho de desempenho com relação à população não se torna mais significativo, tendo até um decréscimo, como se observa no teste 1D.

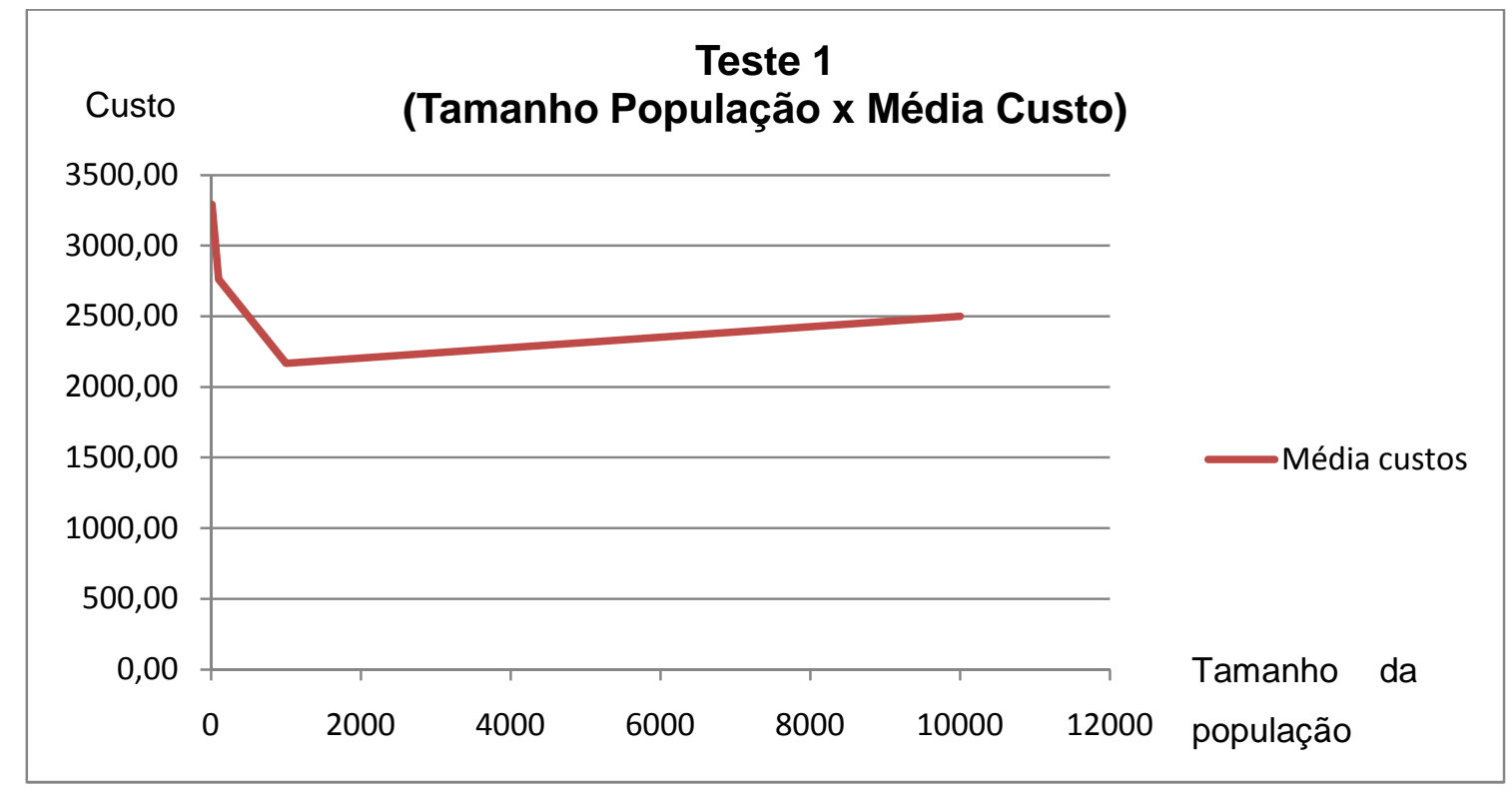




\subsection{MUTAÇÃO - TESTE 2}

Neste teste, a probabilidade de mutação será variada conforme indicado abaixo:

\begin{tabular}{|c|c|}
\hline TESTE & $\begin{array}{l}\text { PROBABILIDADE } \\
\text { DE MUTAÇÃO }\end{array}$ \\
\hline $2 \mathrm{~A}$ & 0.05 \\
\hline $2 \mathrm{~B}$ & 0.01 \\
\hline $2 \mathrm{C}$ & 0.001 \\
\hline 2D & 0.0001 \\
\hline
\end{tabular}

Parâmetros fixos:

- Número máximo de gerações: 100;

- Tamanho da população: 1000;

- Penalização: Conforme Equação 12 ( $\mu=10000)$.

- Critério de parada: Número máximo de gerações ou a população ficar homogênea.

Os resultados obtidos encontram-se nas tabelas a seguir: 


\begin{tabular}{|c|c|c|c|c|c|c|c|}
\hline \multicolumn{8}{|c|}{ TESTE 2A } \\
\hline № & $\begin{array}{c}\text { NÓS } \\
\text { INTERM. }\end{array}$ & $\begin{array}{l}\text { BASE } \\
(\mathrm{cm})\end{array}$ & $\begin{array}{l}\text { ALTURA } \\
(\mathrm{cm})\end{array}$ & As & As' & $\mathbf{R} \$$ & PARADA \\
\hline 1 & 4 & 20 & 90 & $5 \phi 16$ & $4 \phi 16$ & 1577,65 & G38 - PH \\
\hline 2 & 1,4 & 20 & 80 & $7 \phi 12,5$ & $3 \phi 25$ & 1573,97 & G100-MG \\
\hline 3 & $1,2,4$ & 25 & 75 & $3 \phi 20$ & $5 \phi 20$ & 1705,38 & G100-MG \\
\hline 4 & $2,3,4$ & 25 & 135 & $7 \phi 25$ & $4 \phi 12,5$ & 2898,57 & G100-MG \\
\hline 5 & $2,3,4$ & 40 & 110 & $3 \phi 16$ & $7 \phi 20$ & 3071,98 & G100-MG \\
\hline 6 & 3,4 & 35 & 85 & $7 \phi 25$ & $4 \phi 12,5$ & 2443,54 & G100-MG \\
\hline 7 & $1,3,4$ & 20 & 75 & $5 \phi 12,5$ & $4 \phi 20$ & 1403,95 & G33 - PH \\
\hline 8 & 4 & 35 & 110 & $3 \phi 20$ & $7 \phi 16$ & 2701,41 & G32 - PH \\
\hline 9 & $1,2,4$ & 20 & 80 & $6 \$ 16$ & $4 \phi 20$ & 1534,06 & G84 - PH \\
\hline 10 & 2,4 & 35 & 90 & $6 \$ 20$ & $7 \phi 25$ & 2783,08 & G100-MG \\
\hline \multicolumn{7}{|c|}{ MÉDIA (R\$) } & 2169,36 \\
\hline
\end{tabular}

Tabela 11 - Teste 2A

\begin{tabular}{|c|c|c|c|c|c|c|c|}
\hline \multicolumn{8}{|c|}{ TESTE 2B } \\
\hline № & $\begin{array}{c}\text { NÓS } \\
\text { INTERM. }\end{array}$ & $\begin{array}{c}\text { BASE } \\
(\mathrm{cm})\end{array}$ & $\begin{array}{l}\text { ALTURA } \\
(\mathrm{cm})\end{array}$ & As & As' & $\mathbf{R} \$$ & PARADA \\
\hline 1 & 4 & 30 & 45 & $7 \phi 16$ & $6 \phi 16$ & 1528,59 & $\mathrm{G} 81-\mathrm{PH}$ \\
\hline 2 & $2,3,4$ & 25 & 65 & $7 \phi 12,5$ & $6 \phi 116$ & 1411,59 & G100-MG \\
\hline 3 & 4 & 20 & 110 & $7 \phi 12,5$ & $7 \phi 20$ & 2031,46 & G100-MG \\
\hline 4 & $1,3,4$ & 40 & 80 & $6 \$ 16$ & $6 \$ 16$ & 2251,71 & G100-MG \\
\hline 5 & 2,4 & 20 & 170 & $4 \phi 20$ & $6 \phi 12,5$ & 2648,80 & G81-PH \\
\hline 6 & 3,4 & 65 & 175 & $7 \phi 12,5$ & $3 \phi 25$ & 6204,55 & G70-PH \\
\hline 7 & 2,4 & 30 & 125 & $3 \phi 12,5$ & $3 \phi 20$ & 2548,16 & G83- PH \\
\hline 8 & 1,4 & 40 & 110 & $7 \phi 25$ & $3 \phi 16$ & 3205,06 & G72-PH \\
\hline 9 & 4 & 30 & 160 & $4 \phi 25$ & $7 \phi 16$ & 3735,77 & G43-PH \\
\hline 10 & 2,4 & 30 & 80 & $2 \phi 20$ & $5 \phi 20$ & 2179,10 & G95- PH \\
\hline \multicolumn{7}{|c|}{ MÉDIA (R\$) } & 2774,48 \\
\hline
\end{tabular}




\begin{tabular}{|c|c|c|c|c|c|c|c|}
\hline \multicolumn{8}{|c|}{ TESTE 2C } \\
\hline № & $\begin{array}{c}\text { NÓS } \\
\text { INTERM. }\end{array}$ & $\begin{array}{c}\text { BASE } \\
(\mathrm{cm})\end{array}$ & $\begin{array}{l}\text { ALTURA } \\
\text { (cm) }\end{array}$ & As & As' & $\mathbf{R} \$$ & PARADA \\
\hline 1 & $1,2,3,4$ & 30 & 85 & $6 \phi 10$ & $4 \phi 16$ & 2117,91 & G100-MG \\
\hline 2 & $1,2,3,4$ & 35 & 160 & $4 \phi 20$ & $4 \phi 25$ & 3716,47 & $\mathrm{G} 21-\mathrm{PH}$ \\
\hline 3 & $1,3,4$ & 20 & 80 & $4 \phi 25$ & $3 \phi 16$ & 1615,46 & G43-PH \\
\hline 4 & $1,2,3,4$ & 40 & 105 & $7 \phi 12,5$ & $6 \$ 10$ & 2619,53 & G100-MG \\
\hline 5 & 4 & 5 & 70 & $3 \phi 20$ & $4 \phi 16$ & 2095,48 & G100-MG \\
\hline 6 & $1,2,3,4$ & 80 & 90 & $7 \phi 16$ & $7 \phi 10$ & 4029,42 & G70-PH \\
\hline 7 & 3,4 & 20 & 150 & $3 \phi 25$ & $2 \phi 25$ & 2521,09 & G100-MG \\
\hline 8 & $1,2,4$ & 45 & 60 & $7 \$ 20$ & $4 \phi 20$ & 2220,48 & G83-PH \\
\hline 9 & $1,2,3,4$ & 25 & 85 & $2 \phi 16$ & $6 \phi 20$ & 1954,43 & G87-PH \\
\hline 10 & 4 & 20 & 90 & $3 \phi 25$ & $4 \phi 25$ & 1836,55 & G100-MG \\
\hline \multicolumn{7}{|c|}{ MÉDIA (R\$) } & 2472,68 \\
\hline
\end{tabular}

Tabela 13 - Teste 2C

\begin{tabular}{|c|c|c|c|c|c|c|c|}
\hline \multicolumn{8}{|c|}{ TESTE 2D } \\
\hline № & $\begin{array}{c}\text { NÓS } \\
\text { INTERM. }\end{array}$ & $\begin{array}{l}\text { BASE } \\
(\mathrm{cm})\end{array}$ & $\begin{array}{l}\text { ALTURA } \\
\text { (cm) }\end{array}$ & As & As' & $\mathbf{R} \$$ & PARADA \\
\hline 1 & 4 & 20 & 110 & $7 \phi 10$ & $6 \$ 16$ & 1894,37 & G100-MG \\
\hline 2 & 1,4 & 20 & 100 & $4 \phi 25$ & $3 \phi 16$ & 1891,22 & G100-MG \\
\hline 3 & 4 & 35 & 140 & $2 \phi 25$ & $5 \phi 12,5$ & 3288,20 & G49-PH \\
\hline 4 & $2,3,4$ & 35 & 65 & $7 \$ 20$ & $7 \$ 20$ & 2136,47 & G100-MG \\
\hline 5 & $1,2,3,4$ & 25 & 85 & $3 \phi 25$ & $5 \phi 25$ & 2088,19 & G68- PH \\
\hline 6 & 3,4 & 20 & 150 & $3 \phi 12,5$ & $6 \$ 16$ & 2402,29 & G74- PH \\
\hline 7 & $2,3,4$ & 25 & 140 & $7 \phi 25$ & $7 \phi 16$ & 3197,89 & G65- PH \\
\hline 8 & $1,3,4$ & 55 & 70 & $2 \phi 25$ & $5 \phi 12,5$ & 2416,54 & G100-MG \\
\hline 9 & 4 & 20 & 115 & $6 \phi 20$ & $3 \phi 16$ & 2054,11 & G100-MG \\
\hline 10 & 3,4 & 40 & 95 & 3 фp25 & $7 \phi 20$ & 2796,68 & G100-MG \\
\hline \multicolumn{7}{|c|}{ MÉDIA (R\$) } & 2416,60 \\
\hline
\end{tabular}

Tabela 14 - Teste 2D

Pode-se perceber que, em faixas muito baixas de probabilidade de mutação a tendência é que a medida que aumenta-se essa taxa o custo médio aumenta. Até que se chega a um ponto de inflexão e a direção da trajetória muda para uma reta 
descendente. Seriam necessários mais testes para se chegar a uma conclusão mais precisa.

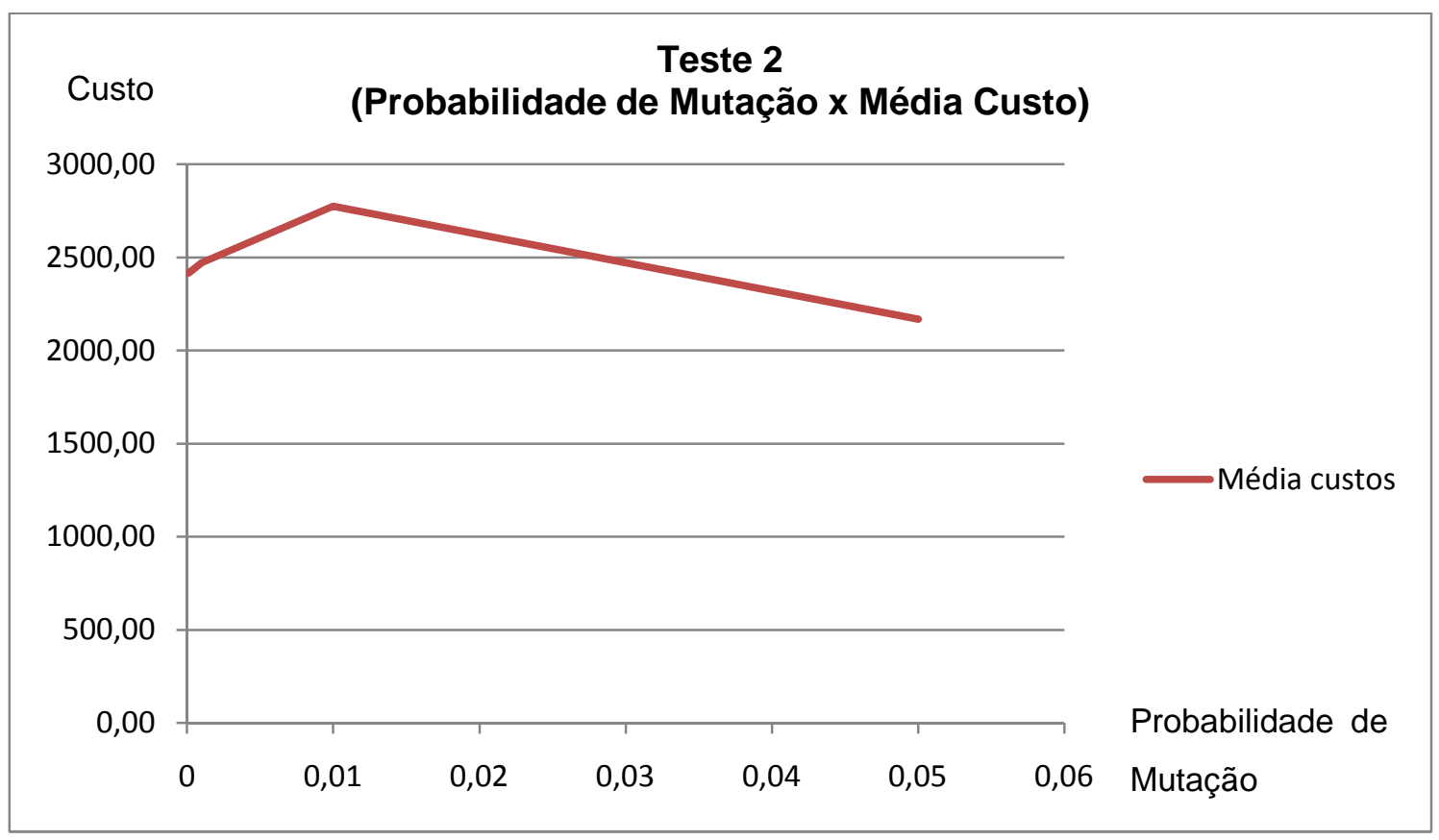

Gráfico 3 - Resultados Teste 2

\subsection{OUTROS PARAMETROS}

Demais parâmetros que influenciam no resultado puderam ser observados nos testes anteriores e as principais observações obtidas serão apresentadas abaixo:

- Número máximo de gerações: observou-se que, quando se trata de populações pequenas o critério de parada com um número máximo de gerações quase não é utilizado, tendo em vista que a população rapidamente fica homogênea (outro critério de parada). À medida que o tamanho da população aumenta e, conseqüentemente sua variabilidade, é que este critério passa a ser determinante, porém, nos casos tratados, ainda em pequena escala. Utilizando-se um valor baixo para este critério, pode acabar obrigando o programa a terminar precocemente o seu processo, sem que para isso tenha explorado muitas possibilidades. Adotando-se um valor 
elevado, condiciona o outro critério de parada (população homogênea) a ser determinante. Com isso, com uma população elevada, faz com que o programa perca muito tempo em processamento, desnecessariamente, tendo em vista que ele só irá parar quando toda a população (que é ampla) ficar homogênea ou quando o número máximo de gerações (que também é elevado) for alcançado.

- População Inicial: observou-se que quando a população inicial era composta por indivíduos ruins, algum indivíduo que possuísse características um pouco melhores logo "dominava" as gerações, fazendo com que a população rapidamente se homogeneizasse e o programa concluísse sem que conseguisse obter uma solução satisfatória. 


\section{CONCLUSÕES}

Essa dissertação abordou o problema de otimização de vigas de concreto armado utilizando um método probabilístico de otimização baseado em algoritmos evolucionários, os Algoritmos Genéticos (AG's). Os AG's procuram simular o comportamento do problema a ser otimizado inspirando-se na teoria da evolução das espécies, proposta inicialmente por Darwin. Ele trabalha com populações de soluções, de forma a explorar o domínio do problema e através de um mecanismo de seleção que privilegia soluções mais próximas da solução ótima, cruza suas informações e gera indivíduos mais bem adaptados que os anteriores.

A motivação para tal estudo veio da necessidade de se buscar soluções exeqüíveis para problemas de otimização de vigas, tendo em vista seu caráter prático de aplicação. Isso porque os Algoritmos Genéticos são um método robusto, capaz de tratar de problemas complexos e trabalhar facilmente com variáveis discretas, além de ser bastante adaptável a mudanças.

Inicialmente foram levantados dados a respeito da aplicação deste método de otimização na área de engenharia de estruturas. Descobriu-se que ele é relativamente antigo, porém só pôde ser desenvolvimento melhor com o aumento da capacidade computacional dos computadores. No âmbito internacional, os AG's em sua maioria são aplicados em estruturas metálicas. Isso se deve ao fato das características homogêneas do aço facilitarem sua implementação. Além disso, o aço é mais utilizado na maioria dos países onde se obteve dados da pesquisa (geralmente países desenvolvidos). Quanto ao concreto, constatou-se que existiam poucos trabalhos que utilizaram este tipo de material. No Brasil foram encontrados muitos trabalhos que utilizavam concreto armado, provavelmente devido ao fato dele ainda ser o material que predomina nas construções, devido ao seu baixo custo.

Descobriu-se também que a grande maioria das pesquisas em otimização de estruturas prefere adotar métodos tradicionais, determinísticos. Ainda existe grande preconceito com relação aos métodos probabilísticos, incluindo os algoritmos genéticos. Muitos pensam se tratar de cruzamentos aleatórios em torno do domínio 
do problema. Porém deve-se levar em consideração que é exatamente pelo seu caráter simples, sem grande complexidade, deixando que a "natureza" resolva o problema é que está a genialidade do método. É bem verdade que se os parâmetros adotados para a resolução do problema não estiverem corretamente ajustados, o método pode vir a se tornar meramente uma busca aleatória. Por isso a importância de se calibrar estes parâmetros. E para cada problema eles deverão ter um comportamento diferente. Por isso cada caso deve ser analisado isoladamente e muitos testes de aferição deverão ser realizados antes de se buscar a resposta final.

Feito isso um problema que se utiliza de Algoritmos Genéticos para encontrar sua solução terá um resultado bastante satisfatório. A questão do custo computacional é um tema importante a ser tratado nos AG's, porém para resolver este problema pode-se utilizar paralelismo, ou seja, deixar várias máquinas trabalhando simultaneamente num mesmo problema, tendo em vista que eles podem ser tratados independentemente. Além disso, os hardwares de computadores têm evoluído consideravelmente ao longo dos anos.

Como objetivo de se aplicar os conceitos dos AG's na otimização de vigas, produziuse um programa em linguagem Java, aplicando-se conceitos de POO, que facilitaram no desenvolvimento do mesmo. O programa otimiza topológica e parametricamente vigas de concreto armado, submetidas a um carregamento distribuído, sujeitas a restrições laterais das variáveis (a fim de tornar o problema compatível com a realidade pratica) e restrições de comportamento em relação ao ELU. Durante o desenvolvimento do programa pode-se sentir as particularidades da aplicação de um método probabilístico de otimização. Notou-se o seu caráter sensível quanto aos parâmetros adotados. Se utilizados de forma adequada o problema consegue resultados satisfatórios, caso contrário pode-se realmente se tornar uma mera busca aleatória, como muitos pensam. Portanto, acredita-se que o principal obstáculo dos AG's seja o ajuste dos seus parâmetros.

Como sugestão para trabalhos futuros pode-se:

- Concluir este projeto, aplicando-se a pavimentos tipo de edifícios fazendo a total integração entre vigas do pavimento, lajes e pilares. 
- Focalizar o desenvolvimento da pesquisa no campo da calibração dos parâmetros, de modo a tentar encontrar valores que sejam menos específicos. Ou seja, diminuir a sensibilidade do problema a estes parâmetros e se possível aplicar a casos mais genéricos.

- Aplicar computação paralela de forma a otimizar o tempo de processamento do projeto. 


\section{REFERÊNCIAS}

[1] Atherly, A.G., J.R. Girton, e J.F. McDonald. The Science of Genetics. Harcourt Brace College Publishers; 1 edition, 1998.

[2] BÄCK, T., U. HAMMEL, e H.P. SCHWEFEL. Evolutionary Computation: Comments on the History and Current State. IEEE Transactions On Evolutionary Computation, vol. 1, oㅜ 1, pp. 3-17, 1997.

[3] Balling, R.J., M. Asce, R.R. Briggs, e K. Gillman. Multiple Optimum size/Shape/Topology designs for skeletal Structures Using a Genetic Algorithms. In Journal os structural Engineering, ASCE. v.132. n7, 2006.

[4] Briggs, R. R. A Genetic Algorithm that Finds all Optimum Topologies of Skeletal. 2004. 131p. Dissertação (Mestrado) - Brigham Young University, Utah, 2004.

[5] Brun, A.L. Algoritmos Genéticos. In: Encontro Paranaense de Computação, I, Cascavel. Apostila EPAC. Paraná, 2005.

[6] Castilho, V. C. de. Otimização de Componentes de Concreto Pré-moldado Protendidos Mediante Algoritmos Genéticos. 2003. 181p. Tese (Doutorado) Escola de Engenharia de São Carlos, Universidade de São Paulo. São Paulo, 2003.

[7] Castro, R.E. Otimização. 1999. 87 p. Monografia (Proposta para insc. direta no Doutorado) - COPPE, Universidade Federal do Rio de Janeiro, Rio de Janeiro, 1999.

[8] - Otimização de Estruturas com Multi-Objetivos via Algoritmos Genéticos. 2001. 206 p. Tese (Doutorado) - COOPE, Universidade Federal do Rio de Janeiro, Rio de Janeiro, 2001. 
[9] Chiam, S.C., C.K. Gom, e K.C. Tan. Issues of Binary Representation in Evolutionary Algorithms. In Cibernetics and Intelligent Systems, 2006 IEEE Conference, 2006.

[10] Cho, H-.N., D-.H. Min, e K.M. Lee. Optimum Life-Cycle Cost Design of Orthotropic Steel Deck Bridges. In: International Journal of Korean Society of Steel Construction, Vol.1, no2, pp.141-153, 2001.

[11] Cohn, M. Z., A.J. Dinovtzer, Fellow, e ASCE. Application of Structural Optimization. In Journal of Structural Engineering, ASCE, v.120, n. 2, 1994.

[12] Croce, E.S., E.G. Ferreira, e A.C.C. Lemonge. A Genetic Algorithm for Structural Optimization of Steel Truss Roofs. In: Congress Iberian Latin-American on Computational Methods in Engineering (CILAMCE), XXV, 2004, Recife. Proceedings. Pernambuco, 2004.

[13] DAVIS, L. Handbook of Genetic Algorithms. Van Nostrand Reinhold, Nova York, 1991.

[14] Deb, K., e S. Gulati. Design of Truss Structures for Minimum Weight Using Genetic Algorithms. In Journal of Finit Element in Analysis and Design. v.37. n. 5, 2001.

[15] Del Savio, A.A., S.A.L. Andrade, P.C.G.S Vellasco, e L.F. Martha. Genetic Algorithm optimization of semi-rigid steel structures. In B.H.V. Topping Internacional Conference on the Aplication of Artificial Inteligence to Civil, Structural and Enviromental Engineering. VIII. 2005. Stirlingshire. Proceedings. Paper 24. Uk, 2005.

[16] Escola Politécnica da Universidade de São Paulo. Diretrizes para apresentação de dissertações e teses. 3 ed. Divisão de Bibliotecas da EPUSP. 103p. São Paulo, 2003.

[17] Gantovnik, V.B. An Improved Genetic Algorithm for the Optimization of Composite Structures. 2005. 111p. Tese (Doutorado) - Faculty of the Virginia Polytechnic Institute and State Institute. Virginia, 2005. 
[18] Gillman, K.M. Optimization of Shape, Size and Topology Design Variables in Trusses with a Genetic Algorithm. 2005. 82p. Dissertação (Mestrado) - Brigham Young University, Utah, 2005.

[19] Goldberg, D.E. Genetic Algorithms in Search, Optimization and Machine Learning. Addison Wesley, 1989.

[20] Grierson, D.E., e W.H. Pack. Optimal Sizing, Geometrical and Topological design using a genetic Algorithm. Journal of Structural Optimization, 6, 151-159, 1993.

[21] Guerra, C. Otimização Paramétrica de Estruturas Treliçadas por Algoritmos Genéticos. 2008. 91p. Dissertação (Mestrado). Escola de Engenharia, Universidade Federal do Rio Grande do Sul, Rio Grande do Sul, 2008.

[22] Haftka, R.T., e Z. Gurdal. Elements of Structural Optimization (Solid Mechanics and its applications). Kluwer Academic Publishers,v.11. 504 p. Dordrecht., 1991.

[23] Holland, J.H. Adaptation in Natural and Artificial Systems. University of Michigan Press, 1975.

[24] Hultman, M. Weight Optimization of Steel Trusses by a Genetic Algorithm. 2010. 65 p. Dissertação (Mestrado). Lund Institute of Tecnology. Lund. Suécia, 2010.

[25] Kicinger, R.P., e T. Arciszewski. Evolutionary Multi-Objetive Design of Steel Structures in Tall Buildings. In: Obayashi, S., editor. Proceeding of the AIAA 1st Intelligent Systems Technical Conference, Chicago, 2004.

[26] Kim, I.Y., e O. Weck. Progressive Structural Topology Optimization by Variable Chromossome Length Genetic Algorithm . In: China-Japan-Korea Jount Symposium on Optimization of Structural and Mecanical Systems, III, 2004, Kanazawa. Proceedings. Japan, 2004.

[27] Koumousis, V.K., e P.G. Georgiou. Genetic Algorithm in Discrete Optimization of Steel Truss Roofs. In Journal of Computing in Civil Engineering, ASCE. v.8. n. 3. , 1994. 
[28] Lima, C.R.N. Análise de Deformação por Fluencia em uma viga de Concreto Armado e protendido: Retroanálise a Algoritmos Genéticos. 2007. 76 p. Dissertação (Mestrado) Escola Politecnica, Universidade de São Paulo, São Paulo, 2007.

[29] Luenberger, D.G. Linear and Nonlinear Programming. SPRINGER VERLAG, 2ed, 2003.

[30] Michalewicz, Z., e R. Hinterding. Evolutionary Algorithms. Chapter 2 in Fuzzy Evolutionary Computation, Kluwer Academic, 1997.

[31] Olivieri, B. P. Otimização do Projeto de Pontes Protendidas Pré-Moldadas pelo Método dos Algoritmos Genéticos. 2004. 129 p. Dissertação (Mestrado) COPPE, Universidade Federal do Rio de Janeiro. Rio de Janeiro, 2004.

[32] Pizzirani, F. Otimização Topológica de Estruturas Utilizando Algoritmos Genéticos. 2003. 86p. Dissertação (Mestrado) - Faculdade de Engenharia Mecânica, Universidade Estadual de Campinas Campinas. São Paulo, 2003.

[33] Rajev, S., e C.S. Krishnamoorthy. Discrete Optimization of Structures using Genetic Algorithm. Journal of structural engineering, ASCE, v.118. n.5, p.12331250., 1992.

[34] Sakla, S., e E. Elbeltagi. Design of Steel Roofs Subjected to Drifed Snow Using Genetic Optimization. In: Journal of Computers and Structures, Elsevier Publishier, vol. 81, no6, pp339-348, 2003.

[35] Silva, E.E. Otimização de Estruturas de Concreto Armado Utilizando Algoritmos Genéticos. 2001. 131p. Dissertação (Mestrado) - Escola Politécnica, Universidade de São Paulo,São Paulo, 2001.

[36] Soares, R.C. Otimização de Seções Transversais de Conccreto Armado Aplicação a Pavimentos. 1997. 145 p. Dissertação (Mestrado) - Escola de Engenharia de São Carlos, Universidade de São Carlos. São Paulo: São Carlos, 1997. 
[37] Tai, K., S. Wang, S. Akhtar, e J. Prasad. Structural Topology Optimization using a Genetic Algorithm and Morphological Representation of Geometry. . In 3rd SMA Annual Symposium, Singapure, 17-18, 2003.

[38] Timoteo, G.T.S. Desenvolvimento de um Algoritmo Genético para a resolução do Timetabling. 2002. 76 p. Dissertação (Graduação) - Universidade Federal de Lavras, Minas Gerais, 2002.

[39] Vianna, L.C.C., e A.L.H Debs. Otimização de Seções Transversais de Concreto Armado: Aplicação a Pórticos. In: Cadernos de Engenharia de Estruturas. São Carlos. 2005. vol.7, nำ6, p.1-32, 2005.

[40] Wang, S., S. Akhtar, J. Prasad, e K. Tai. Structural Topology Optimization Using a Genetic Algorithm and a Morphological Representation of Geometry. In: Singapure-MIT Alliance Annual Simposium, III, 2003, Camberra. Proceedings. Australia, 2002.

[41] Woon, S.Y., O.M. Querin, e G.P. Steven. Structural Application of a Shape Optimization Method Based on Genetic Algorithm. In: Structural and Multidisciplinary Optimization. 2001. vol.22, №1,p. 57-64, 2001.

[42] Zuben, F.J.V. Computação Evolutiva: Uma abordagem Pragmática. Apostila. Campinas: Unicamp, 2004. 


\section{APÊNDICE A}

\section{VALIDAÇÃO DO PROGRAMA - UMA APLICAÇÃO DO AGEN PARA OTIMIZAÇÃO DE SEÇÃO TRANSVERSAL DE UMA VIGA DE CONCRETO}

A fim de validar os conceitos aplicados no programa AGEN, utilizou-se como referência um exemplo aplicado por dois autores da bibliografia, que utilizaram abordagens distintas para resolver o mesmo problema. Trata-se da otimização da seção transversal de uma viga de concreto, biapoiada submetida a um carregamento distribuído. (Soares 1997) adotou o método dos multiplicadores de Lagrange (método determinístico) enquanto (Castilho 2003) utilizou Algoritmos Genéticos (método probabilístico) para resolver o mesmo problema.
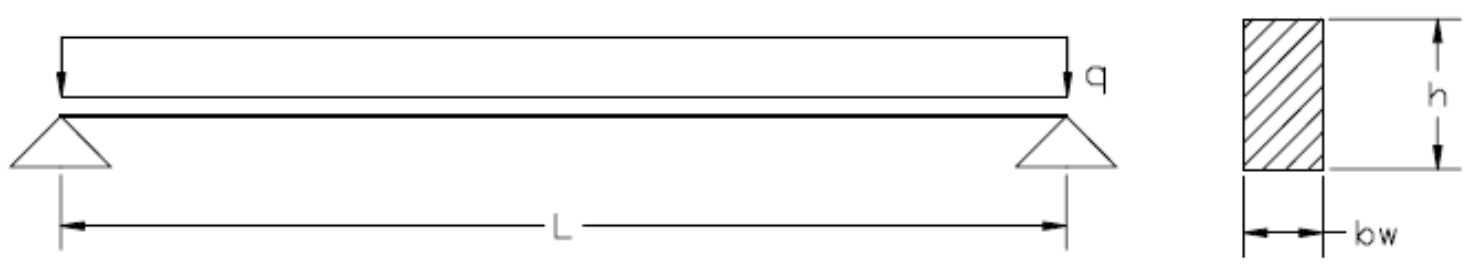

Figura 28 - Exemplo de aplicação

Abaixo segue a formulação:

$$
\min F(x 1, x 2)=b_{w} *\left(x 1+d^{\prime}\right) * C_{C}+(x 2) * \rho_{s} * C_{S}+\left(b_{w}+2 * x 1\right) * C_{F}
$$

Sujeito a:

$$
\begin{aligned}
& \frac{\delta_{i}}{\delta_{\text {Adm }}}-1 \leq 0 \\
& \frac{x 2}{0,075 * x 1}-1 \leq 0 \\
& \frac{M_{d}}{M_{u}}-1 \leq 0
\end{aligned}
$$


$50 \leq x 1 \leq 80(\mathrm{~cm})$

$3.1 \leq x 2 \leq 6.2\left(\mathrm{~cm}^{2}\right)$

Onde:

$\mathrm{x} 1=\mathrm{h}-$ d' (distância do centro de gravidade da armadura tracionada a face mais comprimida).

x2 = Área de armadura;

$\delta_{\mathrm{i}}=$ Flecha máxima para cada indivíduo;

$\delta_{\text {Adm }}=$ Flecha Admissível (L/300);

$M_{d}=$ Momento Atuante de cálculo;

$M_{u}=$ Momento resistente

$\mathrm{L}=8 \mathrm{~m}$;

$q=0.1 \mathrm{KN} / \mathrm{m}(1 \mathrm{tt} / \mathrm{m})$

$d^{\prime}=0.03 \mathrm{~m}$

$b_{w}=0.15 m$

$\mathrm{C}_{\mathrm{c}}=30 \%$ do Custo total (Custo do concreto);

$\mathrm{C}_{\mathrm{a}}=30 \%$ do Custo total (Custo do aço);

$\mathrm{C}_{\mathrm{F}}=40 \%$ do Custo total (Custo da Forma);

$\rho_{s}=75 \mathrm{KN} / \mathrm{m}^{3}\left(7.5 \mathrm{tt} / \mathrm{m}^{3}\right)-$ Densidade do Aço;

Concreto: 20Mpa (C20);

Aço: CA50;

Os resultados encontrados por (Castilho 2003) e (Soares 1997) estão apresentados na tabela a seguir: 


\begin{tabular}{|c|c|c|c|}
\hline \multirow{2}{*}{ Autor } & Método Utilizado & \multicolumn{2}{|c|}{ Resultados Obtidos } \\
\cline { 2 - 4 } & $\mathrm{H}(\mathrm{cm})$ & As $\left(\mathrm{cm}^{2}\right)$ \\
\hline (Soares 1997) & $\begin{array}{c}\text { Multiplicadores de Lagrange } \\
\text { (Determinístico) }\end{array}$ & 67.25 & 4.13 \\
\hline (Castilho 2003) & $\begin{array}{c}\text { Algoritmos Genéticos, } \\
\text { utilizando variáveis continuas } \\
\text { (Probabilistico) }\end{array}$ & 67.25 & 4.33 \\
\hline
\end{tabular}

Conforme visto nos Capítulos 6 e 7, o problema tratado no programa AGEN é bem mais complexo que o tratado no exemplo de validação, portanto algumas adaptações foram feitas para torná-lo compatível com o problema a resolver. Por exemplo, no custo da viga por metro foram eliminados os termos referentes ao custo da armadura superior (negativa) e ao custo dos estribos, conforme se observa abaixo:

$$
C_{v, m}=C_{C} * b * h+C_{a} * n i * \gamma_{d l i}+C_{F} *(b+2 * h)
$$

Equação 16 - Custo de Viga por metro - Adaptada ao exemplo

Sujeito a:

$0.5 \leq h \leq 0.80$, sendo $p H \in M / M=\left\{x / x \in \mathbb{R}^{+}\right.$e $x$ é múltiplo de 0.05$\} \quad(\mathrm{m})$

$d l i=\{1.0,1.25,1.6,2.0,2.5,3.2\}$, dli em $\mathrm{cm}$.

$2 \leq n i \leq 8$, sendo ni $\in \mathbb{Z}$

$M_{S D}^{+} \leq M_{R D}^{+}$

Onde, 
$\mathrm{b}=0.15 \mathrm{~m}$

$\mathrm{C}_{\mathrm{C}}=0.3\left(\mathrm{R} \$ / \mathrm{m}^{3}\right)$

$\mathrm{C}_{\mathrm{A}}=0.3(\mathrm{R} \$ / \mathrm{Kg})$

$\mathrm{C}_{\mathrm{F}}=0.4\left(\mathrm{R} \$ / \mathrm{m}^{3}\right)$

Os parâmetros de entrada utilizados para o algoritmo genético foram:

Tamanho da população: 1000;

Probabilidade de mutação: 0.001;

Critérios de parada:

- População Homogênea ou ;

- $\mathrm{h}=65 \mathrm{~cm}$ e $($ Asi -4.5$)<=0.5$; (Teste 1)

- $\mathrm{h}=70 \mathrm{~cm} \mathrm{e}($ Asi -4.5$)<=0.5$; (Teste 2$)$

Onde Asi = área de aço inferior .

Para cada teste o programa foi aplicado 20 vezes, a fim de verificar a veracidade dos resultados. Abaixo segue tabela com os resultados obtidos:

\begin{tabular}{|c|c|c|c|c|c|c|}
\hline \multicolumn{7}{|c|}{ Teste 1 - Solução Ótima $(65,4.5)$} \\
\hline № & $\mathrm{H}(\mathrm{cm})$ & pNi & pDli $(\mathrm{cm})$ & $\mathrm{As}\left(\mathrm{cm}^{2}\right)$ & Critério de parada & Geração de Parada \\
\hline 1 & 65 & 4 & 1,25 & 5,00 & Solução Ótima & 70 \\
\hline 2 & 65 & 6 & 1,00 & 4,80 & Solução Ótima & 10 은 \\
\hline 3 & 65 & 6 & 1,00 & 4,80 & Solução Ótima & 50 \\
\hline 4 & 65 & 6 & 1,00 & 4,80 & Solução Ótima & 10 - \\
\hline 5 & 55 & 4 & 1,60 & 8,00 & População Homogênea & 660 \\
\hline 6 & 65 & 4 & 1,25 & 5,00 & Solução Ótima & 110 \\
\hline 7 & 70 & 6 & 1,60 & 12,00 & População Homogênea & 640 \\
\hline 8 & 65 & 4 & 1,25 & 5,00 & Solução Ótima & 50 \\
\hline 9 & 65 & 4 & 1,25 & 5,00 & Solução Ótima & 10 은 \\
\hline 10 & 65 & 4 & 1,25 & 5,00 & Solução Ótima & 70 \\
\hline 11 & 65 & 4 & 1,25 & 5,00 & Solução Ótima & 10 은 \\
\hline 12 & 65 & 4 & 1,25 & 5,00 & Solução Ótima & 110 \\
\hline 13 & 65 & 4 & 1,25 & 5,00 & Solução Ótima & 9o \\
\hline 14 & 65 & 4 & 1,25 & 5,00 & Solução Ótima & 15 은 \\
\hline
\end{tabular}




\begin{tabular}{|c|c|c|c|c|c|c|}
\hline \multicolumn{7}{|c|}{ Teste 1 - Solução Ótima $(65,4.5)$} \\
\hline № & $\mathrm{H}(\mathrm{cm})$ & $\mathrm{pNi}$ & pDli (cm) & $\mathrm{As}\left(\mathrm{cm}^{2}\right)$ & Critério de parada & Geração de Parada \\
\hline 15 & 65 & 4 & 1,25 & 5,00 & Solução Ótima & $13 ㅇ$ \\
\hline 16 & 65 & 4 & 1,25 & 5,00 & Solução Ótima & 60 \\
\hline 17 & 80 & 3 & 1,25 & 3,75 & População Homogênea & 910 \\
\hline 18 & 65 & 4 & 1,25 & 5,00 & Solução Ótima & 9o- \\
\hline 19 & 65 & 4 & 1,25 & 5,00 & Solução Ótima & 7으 \\
\hline 20 & 65 & 4 & 1,25 & 5,00 & Solução Ótima & 170 \\
\hline
\end{tabular}

\begin{tabular}{|c|c|c|c|c|c|c|}
\hline \multicolumn{7}{|c|}{ Teste 2 - Solução Ótima $(75,4.5)$} \\
\hline № & $\mathrm{H}(\mathrm{cm})$ & pNi & pDli (cm) & $\operatorname{As}\left(\mathrm{cm}^{2}\right)$ & Critério de parada & Geração de Parada \\
\hline 1 & 70 & 4 & 1,25 & 5,00 & Solução Ótima & $12 \circ$ \\
\hline 2 & 80 & 3 & 1,60 & 6,00 & População Homogênea & 1370 \\
\hline 3 & 70 & 6 & 1,00 & 4,80 & Solução Ótima & 60 \\
\hline 4 & 75 & 2 & 1,60 & 4,00 & População Homogênea & 420 \\
\hline 5 & 70 & 6 & 1,00 & 4,80 & Solução Ótima & 60 \\
\hline 6 & 70 & 4 & 1,25 & 5,00 & Solução Ótima & 10 은 \\
\hline 7 & 70 & 4 & 1,25 & 5,00 & Solução Ótima & 15 운 \\
\hline 8 & 70 & 4 & 1,25 & 5,00 & Solução Ótima & 260 \\
\hline 9 & 70 & 4 & 1,25 & 5,00 & Solução Ótima & 489 \\
\hline 10 & 75 & 5 & 1,25 & 6,25 & População Homogênea & $248^{\circ}$ \\
\hline 11 & 70 & 4 & 1,25 & 5,00 & Solução Ótima & 150 \\
\hline 12 & 70 & 6 & 1,00 & 4,80 & Solução Ótima & 10 은 \\
\hline 13 & 80 & 3 & 1,25 & 3,75 & População Homogênea & 1710 \\
\hline 14 & 60 & 5 & 1,25 & 6,25 & População Homogênea & 650 \\
\hline 15 & 70 & 4 & 1,25 & 5,00 & Solução Ótima & 110 \\
\hline 16 & 75 & 3 & 1,60 & 6,00 & População Homogênea & 350 \\
\hline 17 & 70 & 4 & 1,25 & 5,00 & Solução Ótima & 140 \\
\hline 18 & 70 & 4 & 1,25 & 5,00 & Solução Ótima & 9음 \\
\hline 19 & 70 & 6 & 1,00 & 4,80 & Solução Ótima & 170 \\
\hline 20 & 70 & 4 & 1,25 & 5,00 & Solução Ótima & 80 \\
\hline
\end{tabular}




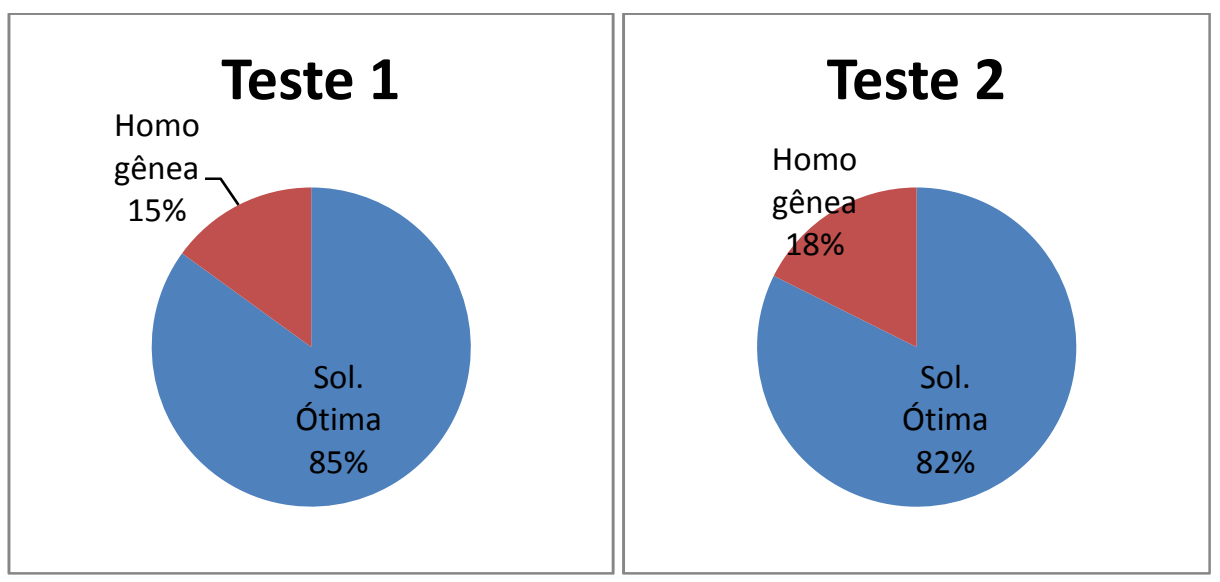

Em $85 \%$ dos casos o programa chegou à solução ótima, portanto pode-se considerá-lo validado. É importante ressaltar alguns pontos:

- À medida que a solução ótima dada como critério de parada do programa se afasta da real solução ótima, o programa vai convergindo para outros resultados, ou seja, ele demonstra que está em busca da solução ótima por mais que se indique um caminho diferente;

- Adotou-se variáveis discretas, ao contrário dos autores de referencia que adotaram variáveis contínuas;

- A restrição de flecha (adotada pelos demais autores), não foi considerada no programa. 


\section{APENDICE B}

TABELA RESUMO COM A FREQUENCIA DE DIVERSOS TRABALHOS DE OTIMIZAÇÃO ESTRUTURAL ORGANIZADOS POR ALGUMAS

CARACTERISTICAS BÁSICAS (Cohn, et al. 1994)

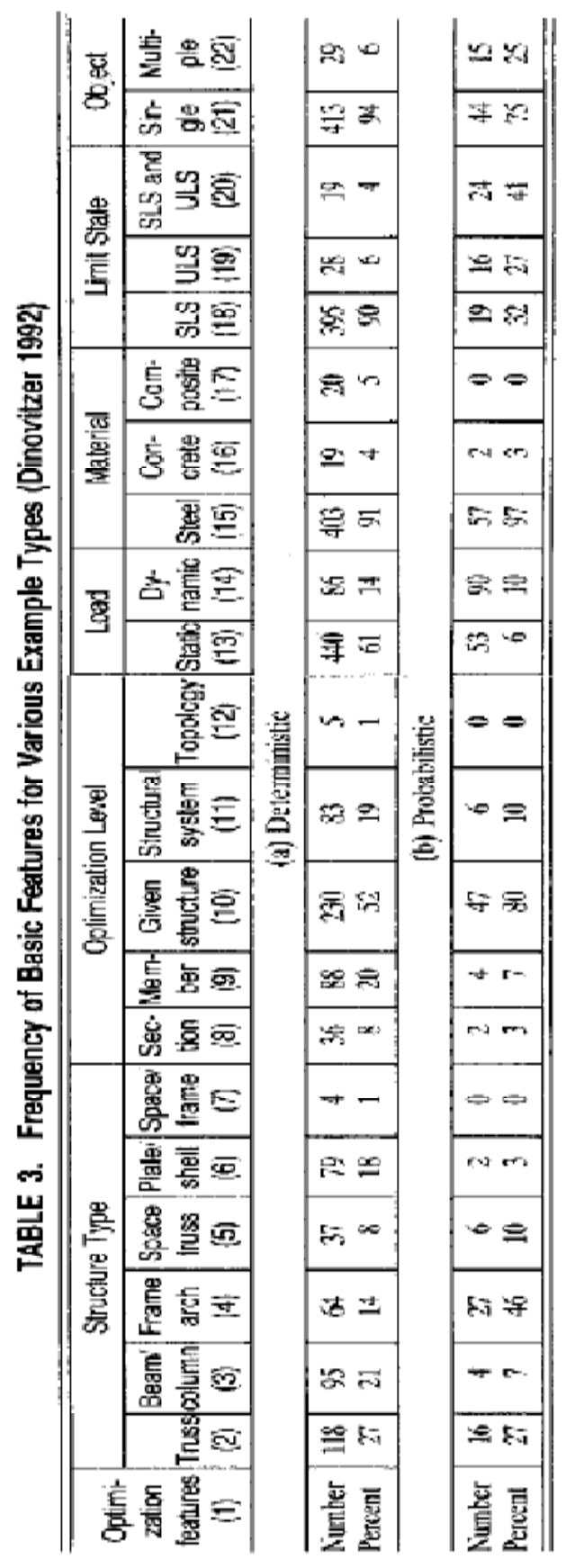

